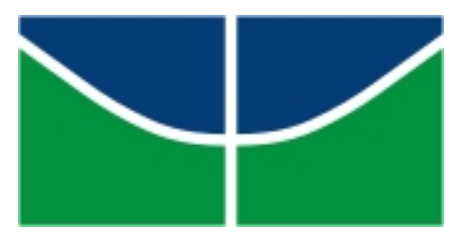

UNIVERSIDADE DE BRASÍLIA

Faculdade de Direito

POR UMA POLÍTICA DE SEGURO DE INVESTIMENTO BRASILEIRO NO EXTERIOR: UMA AVALIAÇÃO SEGUNDO A ANÁLISE JURÍDICA DA POLÍTICA ECONÔMICA (AJPE)

Marcus Thulio Rocha Bezerra

Brasília

Faculdade de Direito da UnB 
Dissertação de Mestrado

Marcus Thulio Rocha Bezerra

\section{POR UMA POLÍTICA DE SEGURO DE INVESTIMENTO BRASILEIRO NO EXTERIOR: UMA AVALIAÇÃO SEGUNDO A ANÁLISE JURÍDICA DA POLÍTICA ECONÔMICA (AJPE)}

Dissertação apresentada à Banca examinadora da Faculdade de Direito da Universidade de Brasília como exigência parcial para obtenção do grau de Mestre em Direito, sob a orientação do Professor Doutor Marcus Faro de Castro.

\section{Brasília}

Faculdade de Direito da UnB 
Marcus Thulio Rocha Bezerra

POR UMA POLÍTICA DE SEGURO DE INVESTIMENTO BRASILEIRO NO

EXTERIOR: UMA AVALIAÇÃO SEGUNDO A ANÁLISE JURÍDICA DA POLÍTICA ECONÔMICA (AJPE)

UNIVERSIDADE DE BRASÍLIA

Faculdade de Direito

Mestrado em Direito

Apresentada à banca examinadora em 15 de março de 2017.

Banca Examinadora:

Presidente: Prof. Dr. Marcus Faro de Castro

Faculdade de Direito da Universidade de Brasília

Integrante: Prof. Dr. Paulo Burnier da Silveira

Faculdade de Direito da Universidade de Brasília

Integrante: Prof. Dr. Fernando de Magalhães Furlan FACIPLAC/UNIPLAC

Integrante: Prof. Dr. Valcir Gassen (suplente)

Faculdade de Direito da Universidade de Brasília 
- O meu nome é Severino, como não tenho outro de pia. Como há muitos Severinos, que é santo de romaria, deram então de me chamar Severino de Maria como há muitos Severinos com mães chamadas Maria, fiquei sendo o da Maria do finado Zacarias.

Mas isso ainda diz pouco: há muitos na freguesia, por causa de um coronel que se chamou Zacarias e que foi o mais antigo senhor desta sesmaria.

Como então dizer quem falo ora a Vossas Senhorias? Vejamos: é o Severino da Maria do Zacarias, lá da serra da Costela, limites da Paraíba.

(João Cabral de Melo Neto) 


\section{AGRADECIMENTOS}

Dizem que nenhuma dissertação se faz sem a ajuda de muitos. É verdade. Se as ajudas intelectuais são devidamente homenageadas nas referências bibliográficas, cabe às próximas linhas a homenagem a todas as outras ajudas - espirituais, familiares e de amigos.

Agradeço demais a Deus por todas as oportunidades que me ofertou, principalmente, desde que cheguei a Brasília. O destino foi tão generoso comigo nos últimos três anos que a sorte que se poderia dizer que tive não pode ser, simplesmente, sorte.

O meu muito obrigado - e a dedicatória deste trabalho - vão à minha família (meus pais Osman e Sandra, minha irmã Mônica, meu cunhado Washington e minha linda sobrinha Maria Antônia) e a Rafaela, minha futura família. Foram, certamente, muitas horas de convívio confiscadas pelas leituras, pelos fichamentos, pelo tempo em frente à tela do computador. A paciência que tiveram comigo nunca foi - e não será - esquecida.

Não posso deixar de registrar minha profunda gratidão ao orientador deste trabalho, o Professor Marcus Faro de Castro. Os encontros que tive com ele durante as aulas de direito econômico, as reuniões do grupo de pesquisa e as sessões de orientação foram de importância ímpar para este início de percurso acadêmico. Em nome do Professor Marcus, prolongo meus agradecimentos aos demais Professores da Faculdade de Direito da UnB com quem tive a oportunidade de conviver em sala de aula. Em ordem alfabética: Airton Seelaender, Ana de Oliveira Frazão, Camila Prando, Menelick de Carvalho Netto, Paulo Burnier da Silveira e Valcir Gassen. Desfrutar de um ensino de alta qualidade e desprovido de vaidade é um privilégio que poderei dizer que tive, graças aos docentes mencionados.

Também merecem um registro especial meus colegas de trabalho, desde os tempos de MDIC, até os atuais no Ministério da Fazenda, por sempre incentivarem a discussão, em âmbito acadêmico, dos temas controversos e áridos que preenchem nossas rotinas. Esta dissertação inicialmente tinha como objeto o programa de Ex-Tarifários, mas minha ida ao Ministério da Fazenda causou, a meu ver, uma feliz mudança de rumos. Em razão dos ótimos debates sobre o tema do seguro de investimento e das ajudas de toda sorte que me ofereceram (desde a elaboração de gráficos menos amadores, passando pela indicação de bibliografia até a revisão de texto), agradeço nominalmente aos excelentes colegas de carreira Lázaro Coelho e Paulo Henrique Mendes e aos não menos excelentes colegas de trabalho Franz Jasper e Hevellyn Albres. Além destes, cito com imensa gratidão os nomes de Marcelo Teixeira e Guilherme Laux, chefes que abraçaram a ideia de minha ida - e lutaram por ela - à Fazenda. Além de ouvirem minhas opiniões com mais atenção do que eu mesmo teria comigo, os dois 
jamais apresentaram qualquer óbice a eventuais compromissos que eu tivesse na UnB e ainda ajudaram, como podiam, para que o trabalho fosse o mais consistente possível. A melhor parte - sempre há uma melhor parte - é ter a certeza de que, no último ano, pude estreitar laços de amizades com todos eles.

Naturalmente, as ajudas sempre melhoram o trabalho, nunca o enfraquecem. Assim, friso que é minha toda a responsabilidade por eventuais erros cometidos nesta dissertação. Além disso, consigno que todas as opiniões aqui emitidas - e não foram poucas - não refletem, necessariamente, o posicionamento oficial do governo brasileiro em geral ou do Ministério da Fazenda, órgão ao qual estou vinculado. Em muitos pontos da dissertação, esses posicionamentos chegam a se opor diametralmente, de forma que, mais uma vez, caberá a mim receber eventuais críticas e discordâncias que a leitura do texto suscitar. 


\section{RESUMO}

Políticas Públicas de apoio a investimentos diretos no exterior há tempos despertam o interesse de governos e atores econômicos em diversos países. Este trabalho tem como objetivo analisar a possibilidade de criação, no sistema normativo brasileiro, do seguro de investimento no exterior. Trata-se de apoio oficial comparável à garantia que Agências de Crédito à Exportação oferecem a empresas multinacionais de seus países com o objetivo de mitigar riscos políticos e extraordinários do investimento no estrangeiro. Para analisar as condições e conteúdos de uma tal política, examinamos o cenário atual de investimentos diretos sob a ótica brasileira, bem como o desequilíbrio entre as políticas de atração de investimentos externos e as políticas de promoção de investimentos ao exterior. Ademais, tratamos especificamente da configuração institucional do seguro de investimento no exterior, abrangendo seus fundamentos econômicos e jurídicos, e aspectos de sua utilização em outros ordenamentos. Ainda inexistente no ordenamento jurídico brasileiro, o seguro de investimento chegou a ser objeto de proposta de lei em 2016. Apesar de aprovada no Congresso Nacional, a criação do seguro foi vetada durante a fase de sanção presidencial, o que indica a existência de controvérsias em relação a esse mecanismo de política econômica. Com base no marco teórico e na metodologia ofertados pela Análise Jurídica da Política Econômica (AJPE), apresentamos um exercício comparativo para contrastar a fruição empírica de direitos de produção dos investidores apoiados por diferentes regimes de seguro de investimento, cotejando os dados com os relativos à fruição empírica de direitos que seria ofertada pelo governo brasileiro caso a proposta de lei vetada houvesse entrado em vigor. Em conclusão, propomos uma nova minuta de projeto de lei, que confira ao investidor brasileiro proteção jurídica equivalente à recebida por seus concorrentes internacionais.

Palavras-chave: investimentos brasileiros diretos. Seguro de investimento no exterior. Análise Jurídica da Política Econômica 


\begin{abstract}
Public policies designed to support outward direct investments have for some time sparked the interest of governments and economic agents in several countries. This paper aims to analyze the possibility of introducing in the Brazilian legal system an Overseas Investment Insurance (OII) against political risks, which is comparable to guarantees offered by Export Credit Agencies to multinational enterprises in many countries. We examine the current scenario of direct investments from the Brazilian perspective and also look at the unbalance between public policies that attract foreign investments into Brazil and those that promote Brazilian investments overseas. Moreover, we investigate the institutional set-up of OII policies, their economic and legal footing and some aspects of their operation in other countries. While still inexistent under Brazilian law, the Brazilian government did sponsor a legislative bill which proposed to institute an OII policy. This bill was vetoed, however, by the Executive before coming into force, a situation that denoted the controversial character of the proposed policy. Finally, based on the theoretical framework and the methodology offered by the Legal Analysis of Economic Policy (LAEP), we engage in a comparative exercise in order to contrast the empirical fruition of "production rights" of investors backed by different OII regimes. The policy features which we describe are then contrasted with the conditions of rights fruition that would be offered by the Brazilian government should the legislative bill have entered into force. To conclude, we propose and elaborate a new draft legislation under which guarantees to Brazilian investors are proposed to be offered, in line with policy parameters comparable to the protection afforded to international investors under foreign laws.
\end{abstract}

Keywords: Brazilian direct investments. Overseas Investment Insurance. Legal Analysis of Economic Policy (LAEP) 


\section{LISTA DE SIGLAS E ABREVIAÇÕES}

ACFI

ABDI

AJPE

APEX

APPI

ASU

BCB

BNDES

BRICS

CAMEX

CMC

CEF

CN

CNI

COFACE

CONCEX

CONEX

CONINV

CPI

ECA

ECGC

ECIC

EDC

EFIC

EMN

FAT

FDC

FDI

FGE

FINEX

GATT
Acordo de Cooperação e Facilitação de Investimentos

Agência Brasileira de Desenvolvimento Industrial

Análise Jurídica da Política Econômica

Agência de Promoção de Exportações

Acordos de Promoção e Proteção Recíproca de Investimentos

Aircraft Sector Understanding

Banco Central do Brasil

Banco Nacional de Desenvolvimento Econômico e Social

Brasil, Rússia, Índia, China e África do Sul

Câmara de Comércio Exterior

Conselho Mercado Comum

Caixa Econômica Federal

Congresso Nacional

Confederação Nacional da Indústria

Compagnie Française d'Assurance pour le Commerce Extérieur

Conselho Nacional de Comércio Exterior

Conselho Consultivo do Setor Privado

Comitê Nacional de Investimentos

Comissão Parlamentar de Inquérito

Export Credit Agency

Export Credit Guarantee Corporation of India Ltd.

Export Credit Insurance Corporation of South Africa

Export Development Canada

Export Credit Agency - Australia

Empresas Multinacionais

Fundo de Amparo ao Trabalhador

Fundação Dom Cabral

Foreign Direct Investment

Fundo de Garantia à Exportação

Fundo de Financiamento à Exportação

General Agreement on Tariffs and Trade 
GMC

IBD

ICSD

ICSID

IED

IFE

KEIC

MAPA

MDIC

Mercosul

MIGA

MP

MRE

NEXI

NOEI

OCDE

OEKB

OMC

ONU

OPIC

PED

PD

PLC

PRI

PROEX

PSIE

PVJ

PWC

RENAI

REINTEGRA

Grupo Mercado Comum

Investimentos Brasileiros Diretos

Investor-State Dispute Settlement

International Centre for Settlement of Investment Disputes

Investimento Externo Direto

Índice de Fruição Empírica

Korea Export Insurance Corporation

Ministério da Agricultura, Pecuária e Abastecimento

Ministério da Indústria, Comércio Exterior e Serviços

Mercado Comum do Sul

Multilateral Investment and Guarantees Agency

Medida Provisória

Ministério das Relações Exteriores

Nippon Export and Investment Insurance

Nova Ordem Econômica Internacional

Organização para a Cooperação e Desenvolvimento Econômico

Oesterreichische Kontrollbank

Organização Mundial do Comércio

Organização das Nações Unidas

Overseas Private Investment Corporation

Países em Desenvolvimento

Países Desenvolvidos

Projeto de Lei Complementar

Political Risk Insurance

Programa de Financiamento às Exportações

Política de Seguro de Investimento no Exterior

Padrão de Validação Jurídica

PricewaterhouseCoopers

Rede Nacional de Informações sobre o Investimento

Regime Especial de Reintegração de Valores Tributários para Empresas

Exportadoras

RMCCI

Regulamento do Mercado de Câmbio e Capitais Internacionais

SACE 
SAIN Secretaria de Assuntos Internacionais do Ministério da Fazenda

SELIC Sistema Especial de Liquidação e de Custódia

SINOSURE China Export and Credit Insurance Corporation

STF Supremo Tribunal Federal

TJLP Taxa de Juros de Longo Prazo

UKEF United Kindom Export Finance

UNCTAD United Nations Conference on Trade and Development 


\section{LISTA DE FIGURAS}

Figura 1: Top 20 Economias receptoras, 2014 e 2015 (em bilhões de dólares). . . . . . 29

Figura 2: Top 20 Economias investidoras, 2014 e 2015 (em bilhões de dólares). . . . . 29

Figura 3: Estoque de Investimento Direto dos BRICS e sua participação no estoque mundial de investimentos diretos (em U\$ Bilhões e em percentual). . . . . . . . 30

Figura 4: Estoque de Investimentos brasileiros diretos 2001-2015 (em US\$ Milhões). . 32

Figura 5: Mudança nas estratégias das empresas frente ao atual contexto político-

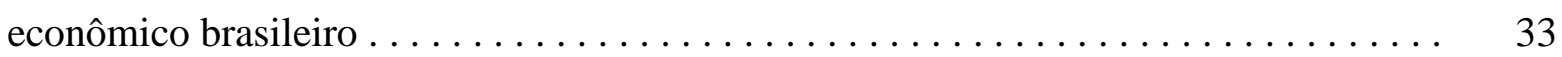

Figura 6: Agências de apoio ao investimento no exterior, divididas por categoria,

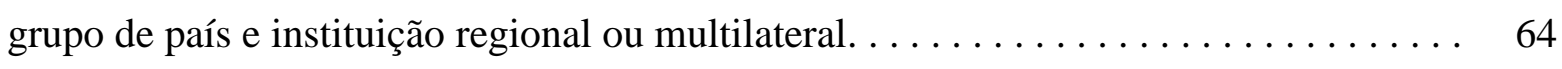

Figura 7: Novos Investimentos Segurados - 2011-2015 (Em Milhões de Dólares). . . 65

Figura 8: Países recipiendários de investimentos segurados - Top 10 - 2015 (em US\$

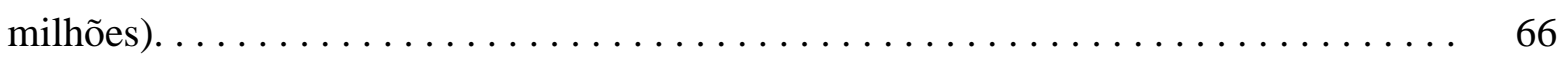

Figura 9: Regiões da primeira subsidiária no exterior. $\ldots \ldots \ldots \ldots \ldots \ldots \ldots$

Figura 10: Países da primeira subsidiária no exterior. . . . . . . . . . . 69

Figura 11: Exposição em Seguro de Investimento 2011-2015 (Em Milhões de Dólares)

Figura 12: Pagamento de indenizações por ano $2011-2015 \ldots \ldots \ldots \ldots \ldots \ldots \ldots$ 


\section{LISTA DE TABELAS}

Tabela 1: América do Sul - Acordos Bilaterais de Investimento . . . . . . . . . 40

Tabela 2: ACFIs negociados/assinados $\ldots \ldots \ldots \ldots \ldots \ldots \ldots \ldots \ldots \ldots \ldots \ldots \ldots \ldots \ldots \ldots \ldots$

Tabela 3: Definição de Investimento em Acordos de Cooperação e Facilitação de Investimentos assinados pelo Brasil $\ldots \ldots \ldots \ldots \ldots \ldots \ldots \ldots \ldots \ldots \ldots \ldots \ldots \ldots \ldots \ldots \ldots$

Tabela 4: Comparativo percentual investimentos segurados 2014-2015 (em US\$

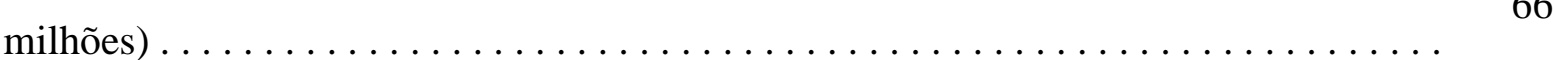

Tabela 5: Receita Operacional do Programa de Seguro de Investimento - PIC/EUA . . 70

Tabela 6: Proposta de Mudança do PLC à Lei Complementar $n^{\circ} 101 / 2000 \ldots \ldots \ldots \ldots$

Tabela 7: Cálculo do Índice de Fruição Empírica (IFE) - Projeto de Lei vetado . . . . 86

Tabela 8: Cálculo do Índice de Fruição Empírica - regimes estrangeiros . . . . . . . . . 87

Tabela 9: Ranking dos IFEs encontrados nas tabelas 7 e $8 \ldots \ldots \ldots \ldots \ldots$ 


\section{SUMÁRIO}

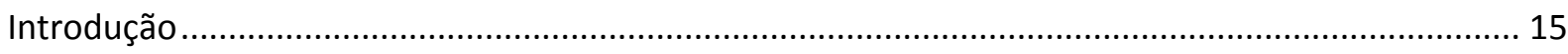

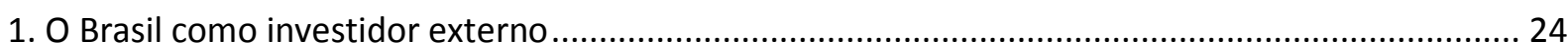

1.1 Determinantes e benefícios do investimento no exterior ............................................................. 25

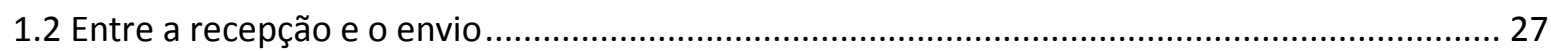

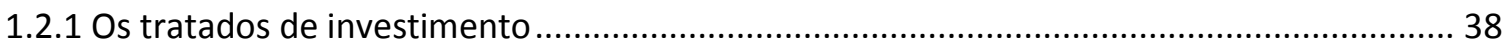

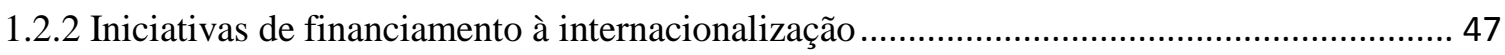

1.2.3. O Comitê Nacional de Investimentos (Coninv): uma nova política para a recepção e o

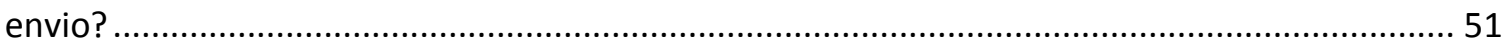

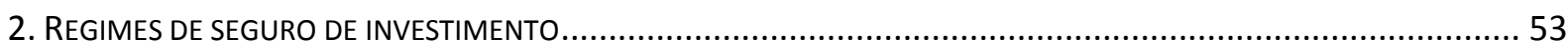

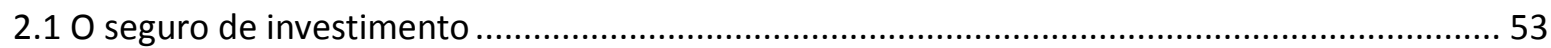

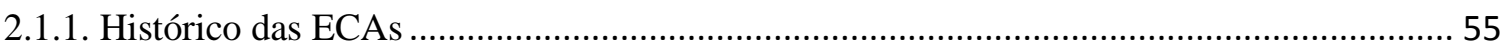

2.1.2. Embasamento econômico do seguro de investimento. O papel das ECAs e as falhas de

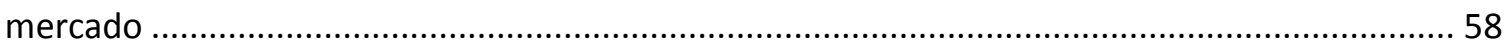

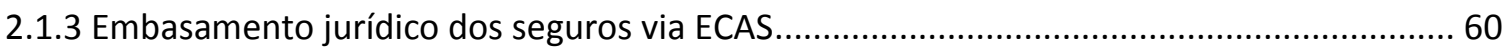

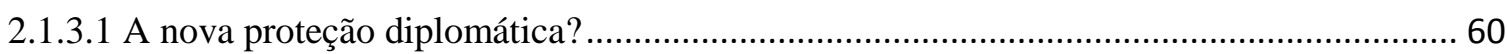

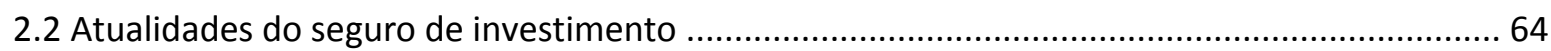

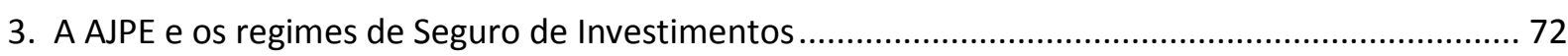

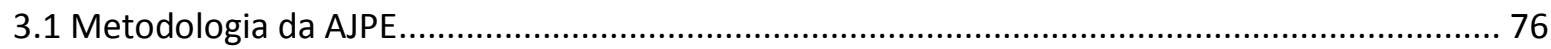

3.1.1 Identificação de política pública ou econômica (ou componente de política pública ou

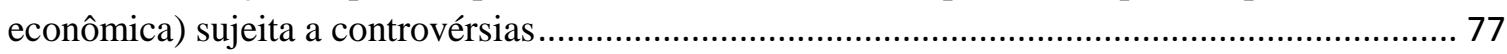

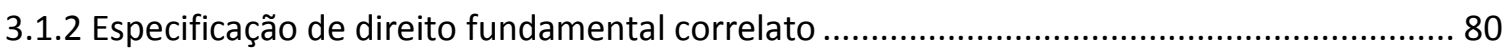

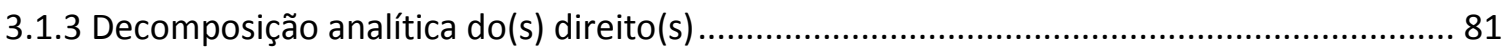

3.1.4 Quantificação dos direitos analiticamente decompostos................................................. 82

3.1.5 A Elaboração de índice de fruição empírica (IFE) e a Elaboração de 'padrão de validação

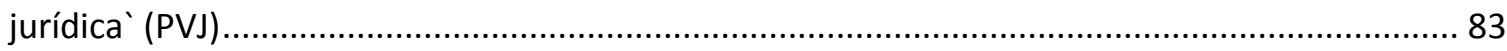

3.1.6 Avaliação dos resultados em termos de verificação da efetividade ou falhas ou ausência de

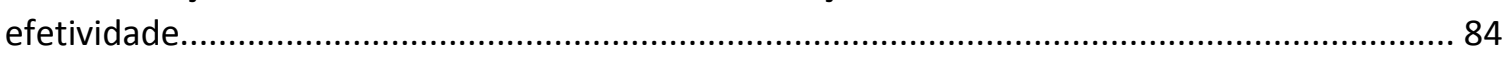

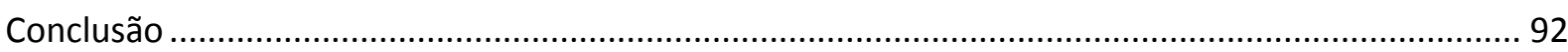

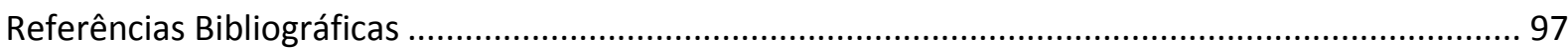

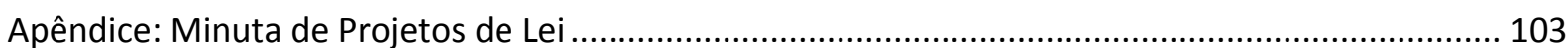




\section{INTRODUÇÃO}

No ano de 2006, o governo boliviano de Evo Morales decretou a nacionalização de minas inativas em poder de empresários que, segundo motivação oficial, não as exploravam. Entre os empresários afetados pela medida de expropriação boliviana, estava o então bilionário Eike Batista, proprietário da empresa de gusa EBX-Bolívia. Ainda que conseguisse recuperar os ativos móveis, o empresário estimava perdas no montante de US\$ 20 milhões ${ }^{1}$.

Poucos meses antes, no mesmo ano, o governo boliviano já havia expropriado refinarias de gás e outros ativos, desta vez de propriedade da Petrobrás. À época, a empresa pública brasileira tinha elevada representatividade econômica na Bolívia, onde investira US\$ 1,5 bilhões (BARRETO, 2012, p. 54). Durante a tomada dos ativos da Petrobrás, o então ministro boliviano de hidrocarbonetos, Andrés Soliz-Rada, alegou a existência de "ganhos extraordinários" então usufruídos pela estatal brasileira - segundo ele, U\$ 320 milhões acima do que permitiria a lei boliviana ${ }^{2}$. Após pouco mais de um ano de negociações, Petrobrás e Bolívia acertaram acordo segundo o qual duas refinarias seriam compradas pelo governo estrangeiro por US\$112 milhões.

Os dois fatos acima noticiados configuram exemplos de uma grande variedade de ações governamentais, adotadas em diversos países, e que têm um impacto negativo sobre a propriedade de investidores estrangeiros. Seja sob a égide de realização de políticas públicas, ou simplesmente por motivações populistas, o fato é que as medidas de expropriação ou nacionalização como as referidas acima são apenas uma amostra de como até mesmo vizinhos de ampla cooperação diplomática com o Brasil podem contribuir para criar tensões entre Estados soberanos de modo a travar significativamente fluxos econômicos na economia internacional.

Se, por um lado, alguns governos podem provocar constrangimentos a investidores estrangeiros, o processo de globalização (liberalização comercial, financeira e em outros setores) mais recentemente passou a sofrer ataques em alguns países que, sob a justificativa de

\footnotetext{
${ }^{1}$ Eike desiste de usina na Bolívia e deve perder US\$20mi. Notícia da Folha de São Paulo. Disponível em http://www1.folha.uol.com.br/folha/dinheiro/ult91u107162.shtml. Acesso em 06.02.2017.

${ }^{2}$ Gás Perdido: Bolívia assume refinarias e Petrobras não recebe nada. Notícia do Conjur. Disponível em http://www.conjur.com.br/2006-set-14/bolivia_assume_refinarias_petrobras_nao_recebe_nada. Acesso em 06.09.2016.
} 
proteger empregos domésticos, têm buscado desestimular, explicitamente, que empresas nacionais realizem investimentos em outros países ${ }^{3}$.

Nesse contexto de tensões de natureza política, mas com consequências econômicas, o Brasil tem buscado, a duras penas, aumentar o grau de internacionalização de suas empresas como estratégia de integração nos movimentos econômicos globais, principalmente por meio do estabelecimento de acordos de investimento com outras economias emergentes. Até o fechamento deste trabalho, o Brasil havia assinado apenas sete Acordos de Cooperação e Facilitação de Investimentos (ACFI) ${ }^{4}$ com México, Chile, Colômbia, Peru, Angola, Moçambique e Malaui. Segundo o Plano Nacional de Exportações, documento publicado pelo então Ministério do Desenvolvimento, Indústria e Comércio Exterior (MDIC) ${ }^{5}$ para o quadriênio 2015-2018, os investimentos no exterior constituem uma estratégia valiosa para a dinamização da economia. O texto documento, nesse sentido, registra:

Os acordos de investimentos contribuem para estimular, acelerar e apoiar os investimentos no exterior, dinamizar a pauta comercial e abrir novas iniciativas de integração. Dessa maneira, esses acordos apoiam o movimento de internacionalização de empresas brasileiras em países nos quais o Brasil possui interesse ativo (atual e potencial).

É claro, portanto, que o governo brasileiro tem, entre suas estratégias de crescimento, o aumento da internacionalização de sua economia. O fluxo de comércio exterior (importações + exportações) não ultrapassou a barreira de 30\% do Produto Interno Bruto nos últimos trinta anos, enquanto a média mundial gira em torno de 50\% (MDIC, 2015, p. 1) ${ }^{6}$. A internacionalização de empresas, nesse ponto, apresenta-se como um instrumento fundamental de aumento da projeção externa de um país, na medida em que fortalece os laços comerciais com parceiros estrangeiros, intensifica a participação brasileira nas cadeias de fornecimento globais e assegura a vinda de recursos ao país do investidor, na forma de lucros

\footnotetext{
${ }^{3}$ Atualmente, as faces mais visíveis de uma guinada neo-protecionista em contraposição ao processo de globalização e liberalização comercial são (i) o "Brexit", referendo ocorrido em junho de 2016 que aprovou, com aproximadamente $52 \%$ dos votos, a retirada do Reino Unido do bloco da União Europeia, com base no art. 50 do Tratado da União Europeia; (ii) a ascensão de Donald Trump ao cargo de presidente dos EUA para o quadriênio 2017-2020. Tanto os pró-Brexit quanto os pró-Trump defenderam, em menor ou maior grau, medidas de diminuição de liberalização econômica sob justificativa de proteção de empregos domésticos.

${ }^{4}$ Até o fechamento deste texto, nenhum dos acordos havia entrado em vigor.

${ }^{5}$ Atualmente, denominado Ministério da Indústria, Comércio Exterior e Serviços.

${ }^{6}$ Ver também: Só 5 países exportam menos que o Brasil em proporção do PIB. Notícia da Folha de São Paulo. Disponível em http://www1.folha.uol.com.br/mercado/2015/07/1661171-so-5-paises-exportam-menos-que-obrasil-em-proporcao-do-pib.shtml. Acesso em 05.02.2017.
} 
e dividendos, contribuindo para a redução do déficit sistêmico em nossa balança de rendas primárias ${ }^{7}$.

Historicamente, o fluxo de investimentos internacionais desenvolveu-se de modo preponderante a partir de países desenvolvidos (PD) e com destino a outros países desenvolvidos ou a países em desenvolvimento (PED). Desde o começo do século XX, pelo menos, discute-se a forma devida de indenizações após atos ostensivos do Estado receptor dos investimentos (expropriações/nacionalizações). Conforme se verá abaixo, as discussões sobre o tema foram alimentadas por incidentes internacionais, os quais fomentaram a criação de princípios de direito internacional até hoje estudados.

Com efeito, a construção de doutrinas jurídicas voltadas à resolução pacífica de conflitos decorrentes de perdas de ativos de empresas transnacionais começou a ganhar força ainda na segunda metade do século XIX, quando o jurista argentino Carlos Calvo, em seus estudos de direito internacional, defendeu, basicamente, a existência de dois princípios a regerem a relação entre investidores externos e Estados receptores de investimentos: (i) sujeição dos investidores externos à jurisdição local; e (ii) proibição de proteção diplomática ou intervenção armada. Essa doutrina foi posteriormente consolidada em forma de cláusula contratual, que se convencionou chamar "Cláusula Calvo" (MAZZUOLI, 2008, p. 471) ${ }^{8}$.

Pouco depois, em 1902, o então chanceler argentino Luis Maria Drago protestou contra o uso da força por parte de potências europeias para garantir o pagamento de dívidas estatais contraídas dos países latino-americanos ${ }^{9}$, várias delas decorrentes de atos de nacionalização de empresas estrangeiras. Esse argumento anti-intervencionista ficou conhecido como "doutrina Drago" (MAZZUOLI, 2008, p. 471). As implicações normativas dessa doutrina foram posteriormente mitigadas por influência da delegação norte-americana na $2^{a}$ Conferência de Paz da Haia, em 1907. A nova convenção "Drago-Porter" passaria a admitir atos de força em casos de (i) recusa de um país em proceder à arbitragem, (ii)

\footnotetext{
${ }^{7}$ A Balança primárias (antiga conta de rendas) compõe o Balanço de Pagamentos do Brasil. Basicamente, ela registra os juros, lucros e dividendos que entram e saem do país. Por exemplo, quando uma multinacional estrangeira reinveste, no Brasil, os lucros de sua subsidiária brasileira, esse registro é feito como um aumento do investimento direto no país. Quando uma subsidiária estrangeira de multinacional brasileira faz o mesmo procedimento, o Banco Central do Brasil (BCB) registra a operação como um aumento do investimento brasileiro no exterior. Com efeito, quando mais empresas no exterior um país tenha, mais ele receberá em lucros, juros e dividendos.

${ }^{8}$ Ver, a respeito da cláusula calvo, o item 2.1.3.1 deste trabalho.

${ }^{9}$ Tratava-se do episódio em que navios ingleses, italianos e alemães bombardearam portos venezuelanos sob a justificativa de que a Venezuela não havia adimplido dívidas contraídas com aqueles três países, os quais teriam sofrido prejuízos financeiros no âmbito de movimentos revolucionários ocorridos naquela nação andina. Em nota diplomática ao governo dos Estados Unidos, Drago firmemente se opôs aos atos de força, posicionando-se contra o emprego de força armada com a finalidade de cobrar dívidas.
} 
impossibilidade de celebração de compromissos ou (iii) inexecução da sentença arbitral (LEONARDI, 2006, p.41).

O desenvolvimento de doutrinas jurídicas internacionais a respeito das indenizações por investimentos nacionalizados gerou outras soluções nacionais. A “fórmula Hull”, de origem norte-americana, no final dos anos 1930 - predicava que as indenizações deveriam ser prontas, adequadas e efetivas. Contudo, as primeiras soluções verdadeiramente multilaterais surgiram apenas no âmbito da Organização das Nações Unidas (ONU), como a Resolução 1803 (14/12/1962), intitulada de "Soberania Permanente sobre os Recursos Naturais" e a Resolução 3281 (12/12/1974), no âmbito do Programa de Ação para a Nova Ordem Econômica Internacional (NOEI), que estabeleceu a "Carta de Direitos e Deveres Econômicos dos Estados".

A busca de maior proteção a investimentos estrangeiros provocou o desenvolvimento mais organizado de tratamento ao tema. Em 1965, foi assinada a Convenção Internacional para Solução de Controvérsias de Investimento (Convenção do ICSID) ${ }^{10}$, com a premissa de que seus Estados signatários melhorariam o ambiente interno de investimentos ao oferecerem mecanismos de arbitragem para a resolução de disputas sobre investimentos (SCHREUER ET AL., 2009, p. xi). O ano de 1976 foi marcado pela celebração das Diretrizes para as Empresas Multinacionais no âmbito da Organização para a Cooperação e Desenvolvimento Econômico (OCDE), um anexo à Declaração da OCDE sobre Investimento Internacional e Empresas Multinacionais, representando um instrumento multilateral de conduta empresarial responsável, que abrange diversos temas, como meio ambiente, direitos trabalhistas e, mais recentemente, direitos humanos (ALBRES, 2014). A abordagem do tema ganhou projeção ainda maior com a edição, pela Organização das Nações Unidas (ONU), do chamado Código de Conduta para Empresas Transnacionais, visando estabelecer padrões de conduta para as multinacionais e de regulação para os países receptores, de forma a garantir um ambiente mais propício e previsível aos investimentos.

Paralelamente ao desenvolvimento de formas políticas e jurídicas voltadas à padronização de condutas por parte de países e empresas no tocante aos investimentos estrangeiros, as últimas décadas do século XX foram marcadas pela formação de regimes jurídicos especiais, de natureza nacional e multilateral, voltados à criação de instrumentos jurídico-financeiros que mitigassem o risco de atos hostis a empresas estrangeiras, minorando

\footnotetext{
${ }^{10}$ A Convenção, que entrou em vigor em 14 de outubro de 1966 após a ratificação dos primeiros 20 estados signatários, pode ser consultada no seguinte endereço: https://icsid.worldbank.org/en/Pages/icsiddocs/ICSIDConvention.aspx. Acesso em 10.02.2017.
} 
as perdas dos investimentos internacionais. Citam-se, para cada caso, o estabelecimento da Overseas Private Investment Corporation (OPIC) nos Estados Unidos, em 1975 ${ }^{11}$; e da Multilateral Investment Guarantee Agency (MIGA) ${ }^{12}$, no âmbito do Grupo Banco Mundial, em 1988. Entre outras funções, ambas as agências promovem investimentos por meio da contratação de seguros de investimento contra riscos de natureza política e extraordinária ocorridos no Estado receptor. Por meio do pagamento de um prêmio (e, eventualmente, apresentação de contragarantias), empresas multinacionais podem mitigar os riscos de suas empreitadas internacionais, sendo indenizadas pela agência contratada em caso de encampação, nacionalização, obstáculos à transferência ou convertibilidade de divisas, atos de guerra ou eventos congêneres de natureza não comercial que causem prejuízos financeiros ao investimento.

A construção de um regime especial dessa natureza envolve o alinhamento de interesses múltiplos. Uma tipologia de tais interesses é útil para fins de análise. Nesse sentido, vale a pena distinguir entre: (i) os interesses do investidor: são os interesses da empresa multinacional, que repassa a outro ente, mediante contrato, a assunção de riscos não comerciais que causem prejuízos a seus investimentos no exterior; (ii) os interesses do Estado garantidor, que fomenta a internacionalização de suas empresas, ao mesmo tempo em que deverá lucrar com a atividade, mediante a correta calibragem atuarial dos prêmios e da eficiente distribuição de portfólio; e (iii) os interesses do Estado receptor, o qual também se beneficia dos investimentos realizados em seu território, na medida em que eles promovem a geração de emprego e renda locais.

Os interesses acima mencionados congregam, entre outros, elementos jurídicos, macroeconômicos, financeiros e de política externa. Tais interesses podem ser estudados a partir de diferentes perspectivas disciplinares: (a) economia internacional; (b) teoria das relações internacionais e sua subdisciplina, economia política internacional; e (c) direito internacional. O presente trabalho tem por objetivo apreciar, desde uma perspectiva jurídica específica, denominada Análise Jurídica da Política Econômica (AJPE), como um regime oficial de seguros de investimento no exterior, caso seja implantado no Brasil, pode afetar positivamente a fruição dos chamados "direitos de produção" da empresa brasileira que realize investimentos diretos no estrangeiro. Assim, ainda que várias passagens desta dissertação contemplem os interesses do Estado garantido e os do Estado receptor, o principal

\footnotetext{
${ }^{11}$ https://www.opic.gov/what-we-offer/political-risk-insurance

${ }^{12}$ https://www.miga.org/investment-guarantees
} 
foco da análise recairá sobre os interesses da empresa brasileira que invista no estrangeiro. Portanto, a principal questão a ser enfrentada na dissertação é: como o direito - em especial, a análise jurídica - pode ajudar na criação e no aprimoramento de políticas públicas que promovam a internacionalização de empresas brasileiras?

A discussão desenvolvida adotará, como já indicado, a perspectiva da AJPE e sua metodologia. Tal perspectiva, explicitada por Castro (2009 e 2014), foi escolhida para fins do presente trabalho, predominantemente em razão dos seguintes aspectos:

- A AJPE tem como premissa fundamental a interdisciplinaridade, o que é particularmente importante no estudo de temas econômicos no campo do direito;

- Ainda que tenhamos conhecimento de outras metodologias que interrelacionem direito e economia (por exemplo, a Análise Econômica do Direito ou a perspectiva conhecida como Direito e Finanças), a aplicação da AJPE implica a formulação de argumentos de facilitada assimilação pelos juristas, pela forma direta mediante a qual o vocabulário não jurídico (notadamente, o econômico) é apresentado e instrumentalizado nas análises.

- A visão da AJPE, segundo a qual direito não é visto não como um sistema estático e impermeável, mas, ao contrário, como produto vivo, uma construção que influencia e sofre influência de fatores sociais, políticos, econômicos e culturais.

- A metodologia da AJPE não se limita a absorver acriticamente instrumentos da chamada teoria neoclássica de economia, mas, sim, conjuga critérios econômicos e sociológicos, com vistas a encontrar metas razoáveis, relativas à fruição de direitos subjetivos. Medir a fruição de direitos é um exercício constante proposto pela abordagem da AJPE, não importa qual área do direito se estude.

- A abordagem da AJPE permite não somente identificar falhas na fruição desses direitos, mas, também, apresentar propostas de reformas legais em razão dos resultados encontrados.

Apresentados em linhas gerais o objetivo e a metodologia do trabalho, passa-se à descrição da divisão dos capítulos.

O primeiro capítulo aborda o tema dos investimentos diretos. A maior parte das obras brasileiras a esse respeito tem como principal objeto de análise o Brasil como receptor de investimentos, e muitas delas propõem alterações regulatórias com vistas a melhorar o 
ambiente jurídico nacional ao capital estrangeiro (BARRETO, 1999; ANDRADE, 2008; 2012; MATTOS, 2015). Essa tendência do estudo do Brasil como Estado receptor não se dá por acaso. Conforme se verá, nosso país se encontra, já há algum tempo, entre os dez principais destinos de investimentos externos diretos. O outro lado da moeda, isto é, a análise do Brasil como investidor no exterior, não é explorado na academia com a mesma frequência. O presente trabalho busca realizar um exame da importância, para o Estado brasileiro, de mudança dessa percepção. Embora ainda haja altas autoridades brasileiras que neguem a tese de que o Brasil seja uma economia fechada ${ }^{13}$, a posição defendida neste trabalho é a de que o país não encoraja o crescimento de uma cultura empreendedora internacional, excetuados os casos de alguns poucos setores. Causa e efeito disso é a existência de circunstâncias limitadoras à expansão de empresas brasileiras no mercado estrangeiro por meio de investimentos diretos, etapa comumente posterior à fixação da presença efetiva de tais empresas no mercado mundial via exportações de produtos ou serviços. Este estudo procura demonstrar que, quando existente o apetite para investir no exterior, os destinos mais atraentes para os investimentos de empresas brasileiras costumam apresentar riscos políticos que militam contra a empreitada transfronteiriça. Por causa disso, a realização plena dessas potencialidades pode ser facilitada por instrumentos jurídicos a serem fornecidos pelo Estado brasileiro. Atualmente, contudo, esses mecanismos ou não existem ou são insuficientes para apoiar o interesse de empresas brasileiras que investem no exterior.

No segundo capítulo, o trabalho aborda especificamente o Seguro de Investimento no exterior $^{14}$, principal objeto desta dissertação. Foram apresentados uma definição teórica do mecanismo, seus fundamentos econômico e jurídico e também aspectos históricos e atuais do tema. O capítulo tem o importante objetivo de situar essa forma de participação do Estado na

\footnotetext{
13 "Não dou aula há muito tempo, mas estudei bastante e tenho uma formação razoável. O Brasil não é uma economia fechada mais do que a média mundial, apesar do folclore. Isso é folclore", disse o Ministro das Relações Exteriores do governo Temer, José Serra, em entrevista concedida durante a cúpula do G-20 em Hangzou, China, em 04.09.2016. Disponível em http://economia.estadao.com.br/noticias/geral,imagem-deprotecionista-do-brasil-e-folclore-afirma-serra,10000074068. Acesso em 07.09.2016.

${ }^{14}$ A denominação do seguro merece uma ressalva do autor. Para fins deste trabalho, chamarei de "seguro de investimento no exterior" o seguro voltado a indenizar perdas financeiras causadas, majoritariamente, por riscos políticos. Esse tipo de seguro é conhecido, no exterior, como Overseas Investment Guarantee, Overseas Investment Insurance ou Political Risk Insurance (PRI). Sem embargo do foco em eventos políticos, a concepção estrangeira de riscos políticos abrange, também, eventos naturais, como catástrofes, inundações, terremotos etc. No Brasil (e para fins de seguro da União), esses eventos são distintamente conhecidos como "riscos extraordinários". Conforme se verá, os riscos extraordinários também serão objeto da proposta legislativa do seguro de investimento no exterior. Utilizarei, portanto, o termo "seguro de investimentos no exterior" de forma mais genérica, abrangendo tanto os riscos políticos quanto os riscos extraordinários. Além disso, apesar de a bibliografia técnica (SALCIC, 2014) indicar que as expressões "seguro" e "garantia" se referem a produtos com características um pouco diferentes entre si, os mencionados termos serão utilizados indistintamente neste texto.
} 
economia, pois, em geral, a doutrina tradicional na área de direito econômico não apresenta subsídios que defendam ou desafiem as racionalidades desse mecanismo.

O capítulo terceiro articula os conceitos apresentados nos dois primeiros capítulos para discutir uma eventual implantação do seguro de investimento no Brasil. Para tanto, o estudo beneficia-se da metodologia da AJPE. O processo metodológico implica a redução, a indicadores numéricos, de características de diferentes regimes de seguro de investimento. Essa transformação de palavras em números teve o objetivo de verificar quais modelos ensejaram maior fruição de "direitos de produção" pelos contratantes do seguro. A utilização de vocabulário não jurídico para a busca do justo se dá pela facilidade que os números trazem quando da realização de qualquer análise comparativa.

O resultado alcançado não tem qualquer pretensão de representar uma solução “onesize-fits-all", por meio de propostas de transplante legal baseadas em tradições jurídicas que não se coadunam com a realidade brasileira. Ele será utilizado com o devido temperamento para a sugestão de um regime a ser implantado no Brasil, momento em que também se levará em conta o Projeto de Lei de Conversão nº 07/2016 à Medida Provisória no 701/2015. A parte desse projeto relativa ao seguro de investimento foi vetada pela Presidência da República em 31 de maio de $2016^{15}$, sob a justificativa genérica de elevar "sobremaneira o risco potencial do $\mathrm{FGE}^{16} \mathrm{e}$, com isso, podendo gerar possíveis impactos fiscais relevantes à União". As características reputadas essenciais a um regime brasileiro de seguro de investimentos no exterior, assim como os procedimentos legais necessários para tanto, serão explicitados na última parte do capítulo. Em apêndice próprio, essas sugestões foram transformadas em minuta de Projeto de Lei, a fim de facilitar o estudo ulterior do tema.

No que diz respeito aos diferentes regimes de seguro de investimento analisados no Capítulo 3, é preciso lembrar que qualquer recorte de pesquisa implica escolhas. Por um lado, quanto ao objeto do presente estudo, caso o autor optasse por examinar os regimes das vinte maiores economias, seria possível alegar desequilíbrio entre países em desenvolvimento e países desenvolvidos, de modo que escolher os países do G-20 pareceria ser uma opção mais representativa. Por outro lado, eventual escolha do G-20 também enfrentaria críticas, pois deixaria de lado importantes países investidores, como Suíça e Espanha. Assim, o autor optou

\footnotetext{
${ }^{15}$ Proferido por meio da Mensagem de Veto no 304.

${ }^{16}$ Segundo o art. $1^{\text {o }}$ da Lei no 9.818, de 23 de agosto de 1999, o Fundo de Garantia à Exportação (FGE) é fundo de natureza contábil, vinculado ao Ministério da Fazenda com a finalidade de dar cobertura às garantias prestadas pela União nas operações de seguro de crédito à exportação, nos termos da Lei. O FGE, portanto, lastreia as indenizações eventualmente pagas em caso de sinistro ocorrido em operações cobertas pelo seguro de crédito à exportação.
} 
por examinar um número menor de regimes, que conjugassem relevância econômica e representatividade na estratégia política de seus países. Em seu processo de recorte, o autor não partiu do nada, mas aproveitou substancialmente catalogações já realizadas por Gordon (2008), sob os auspícios da OCDE. Isso se deveu ao nível relativamente uniforme de acesso à informação, a fim de que as comparações não fossem amparadas em dados assimétricos. 


\section{O BRASIL COMO INVESTIDOR EXTERNO}

Antes de mais nada, é preciso apresentar ao leitor o conceito de Investimento Externo Direto (IED), fundamental para os propósitos deste trabalho. O IED pode ser definido como a transferência de recursos da unidade matriz (parent firm) de uma empresa multinacional para uma unidade receptora (host firm) em outro país, geralmente uma filial ou subsidiária, ou até mesmo uma outra firma em situações de joint venture ${ }^{17}$ (SPERO; HART, 1997, p. 96). A finalidade dessa transferência é obter controle ou propriedade sobre ativos fora do país de origem. Sob outro ponto de vista, pode-se dizer que a internacionalização de empresas se refere ao engajamento de determinada firma em IED e no desenvolvimento de unidades de negócios estrangeiras (RAMSEY; BARAKAT; CREITOIU, 2012, p. 23).

O entendimento predominante no estudo de IED pressupõe a existência de "controle ou propriedade" quando o investidor tem $10 \%$ ou mais em ações da empresa receptora das transferências $^{18}$. A propriedade de menos de $10 \%$ indicaria a inexistência de controle e, consequentemente, a existência do que se convencionou chamar "investimento em portfólio". Södersten e Reed (1994, p. 462) ilustram que o investimento em portfólio pode assumir diferentes formas, como a compra de ações, a aquisição de títulos do governo estrangeiro ou o empréstimo em favor de uma companhia estrangeira.

A Circular $n^{\circ} 3.689$, de 16 de dezembro de 2013, do Banco Central do Brasil (BCB) disciplina o investimento brasileiro no exterior, apresentando a mesma diferenciação entre investimento direto e investimento em portfólio. Considera-se investimento brasileiro direto no exterior "a participação, direta ou indireta, por parte de pessoa física ou jurídica, residente, domiciliada ou com sede no País, em empresa constituída fora do Brasil” (art. 11). Esse conceito era reafirmado na legislação anterior, o Regulamento do Mercado de Câmbio e Capitais Internacionais (RMCCI) ${ }^{19}$, revogado em 02/02/2014. A noção de participação ganha maiores contornos no artigo seguinte da mesma Circular, em especial, na referência a

\footnotetext{
17 Em conformidade com o Glossary of Tax Terms da OCDE (disponível em http://www.oecd.org/ctp/glossaryoftaxterms.htm\#E) e para os fins deste trabalho, definiremos joint venture como a associação entre duas ou mais empresas que buscam atingir um objetivo ou ganho individual, seja para um novo projeto, seja para uma atividade já existente.

${ }^{18}$ Assim entendem, por exemplo, Krugman e Obstfeld (2005). Segundo os autores (idem, p. 126), “nos Estados Unidos, uma empresa é tida como controlada por estrangeiros - e, portanto, uma filial de uma multinacional com sede no estrangeiro - se 10 por cento ou mais de suas acoes pertencerem a uma empresa estrangeira: a ideia é que 10 por cento são suficientes para transferir o controle efetivo. Uma empresa com sede nos Estados Unidos é considerada multinacional se iver uma parcela do controle de empresas no exterior.
}

${ }^{19}$ RMCCI, Título 2, Capítulo 3, Seção 1.1. 
“transferências de recursos para fins de instalação de dependências fora do País e participação societária, direta ou indireta, no exterior" (art. 12). Já o investimento em portfólio é considerado a transferência do e para o exterior em moeda nacional ou estrangeira, relativa a investimento no exterior, por parte de fundos de investimento" (art. 16).

Além das definições conceituais, a Circular no 3.689/2013 reforça o entendimento sobre as imbricações entre exportações e investimentos no exterior, ao autorizar, em seu art. $9^{\circ}$, que "a parcela dos recursos em moeda estrangeira mantida no exterior relativa aos recebimentos de exportações brasileiras de mercadorias e de serviços, realizadas por pessoas físicas ou jurídicas, somente pode ser utilizada para a realização de investimento, aplicação financeira ou pagamento de obrigação próprios do exportador” (destaque nosso).

\subsection{Determinantes e benefícios do investimento no exterior}

São variadas as teorias econômicas que buscam justificar o porquê de uma empresa escolher o investimento externo direto, ao invés de buscar outras vias de internacionalização de atividades (ou manter-se somente nelas), como as exportações. Spero e Hart (1997, pp. 109-112) listam seis teorias não excludentes para levantar determinantes de uma internacionalização via IED:

(i) a teoria da internalização (internalization theory), segundo a qual os custos de transação de concluir contratos de longo prazo $^{20}$ com uma firma externa são maiores do que os custos de estabelecer uma nova unidade externa para atingir o mesmo fim. Assim, as multinacionais prefeririam "internalizar" suas atividades para mitigar essas imperfeições de mercado;

(ii) a teoria do ciclo do produto (product cycle theory) também poderia influenciar a decisão de expansão via IED. Ela argui que as empresas introduzem novos produtos em seus mercados e, a partir do momento em que o mercado doméstico fica saturado (com a demanda recuando), há uma tendência para estabelecer subsidiárias estrangeiras com custos mais baixos, a fim de prolongar a vida do produto;

(iii) por sua vez, a teoria da barganha declinante (obsolescing bargain theory) aduz, de maneira similar à teoria do ciclo do produto, que uma firma que investiu no país receptor começa suas atividades com uma posição de

\footnotetext{
${ }^{20}$ Esses contratos envolveriam, entre outros, problemas de transferência de tecnologia, compromisso de confidencialidade, assimetria de informação entre a empresa doméstica e a estrangeira.
} 
barganha perante o governo estrangeiro, em razão do capital e da tecnologia exportados. Após a realização do investimento, no entanto, a posição de barganha tende a mover-se para o lado do governo.

(iv) A teoria do oligopólio (oligopoly theory) é também listada pelos autores. Eles salientam que as firmas que praticam IED buscam explicar o poder de monopólio que possuem através de fatores como produtos únicos, expertise em marketing, controle de tecnologia e conhecimentos gerenciais. Essa ação externa, contudo, é motivada também por competições internas oligopolistas. Caso uma empresa vá ao exterior abrir firmas, seus competidores serão levados a atuar também no exterior como postura defensiva, a fim de evitar que a pioneira ganhe vantagens extraordinárias.

(v) Por fim, a hipótese de pulo de tarifa (tariff-jumping hypothesis) indica que as multinacionais tentariam esquivar-se de barreiras tarifárias e não tarifárias ao estabelecer subsidiárias no exterior.

Por sua vez, John Dunning (1992) elenca quarto determinantes para uma empresa multinacional (EMN) direcionar investimentos no exterior: (i) o resource-seeking, ou a busca de recursos; (ii) o market seeking, ou a busca de mercados; (iii) o efficiency-seeking, ou a busca de eficiência; (iv) por fim, a busca de ativos estratégicos. Enquanto as duas justificativas iniciais projetam-se para os investimentos direcionados aos países em desenvolvimento, os dois últimos determinantes relacionam-se, geralmente, a países desenvolvidos.

A lógica apresentada por Dunning decorre de uma perspectiva concentrada nos países desenvolvidos na condição de exportadores de recursos. Os dados mais recentes sobre a origem dos investimentos externos, contudo, demonstra um peso cada vez maior de países em desenvolvimento na condição de "investidores". Nesse caso, é possível inferir que o efficiency-seeking também é buscado em mercados emergentes, porque eles representam, em muitos casos, o primeiro case de internacionalização de empresas também oriundas de países emergentes.

Mais recentemente, ao realizar revisão literária sobre os fatores determinantes dos investimentos externos, Sahoo, Nataraj e Dash (2014), resumem tais fatores em dois grupos:

1. Condições econômicas, como tamanho do mercado, perspectiva de crescimento, taxa de retorno, industrialização, custos trabalhistas, infraestrutura física e fundamentos macroeconômicos; e 
2. Políticas do país hospedeiro, como a proteção da propriedade privada, políticas comerciais, política de atração de investimentos externos, estrutura legal e governança.

Os diversos determinantes acima citados coadunam-se com as justificativas apresentadas pelo governo brasileiro na sua política oficial de apoio à internacionalização de empresas. De acordo com o Plano Nacional de Exportações 2015-2018 do Ministério de Desenvolvimento, Indústria e Comércio Exterior (MDIC),

(...) o Brasil é, tradicionalmente, um grande receptor de investimentos externos. Ao longo das últimas décadas, todavia, o País testemunhou o crescimento dos investimentos das empresas brasileiras no exterior. Tal dinâmica do setor produtivo nacional, que reflete a crescente integração produtiva mundial, fundamenta-se na busca por matérias-primas, pela diversificação de mercados, pela geração de economias de escala, por um melhor acesso aos mercados de capitais e tecnologias e pela integração da produção nacional em cadeias de valor globais. Ciente dessa nova realidade, o Governo brasileiro desenvolverá ações abrangentes que favoreçam a internacionalização das empresas nacionais como estratégia de expansão de mercados, ganhos de escala, consolidação de marcas e de empresas em nível regional/global, com consequente reflexo positivo em suas estratégias de inovação. (grifos nossos)

\subsection{Entre a recepção e o envio}

Conforme dito acima, os investimentos externos diretos constituem parte relevante da dinâmica econômica internacional, pois sua grandeza dita a velocidade dos processos de internacionalização das empresas transnacionais, bem como indica o grau de intensificação das relações econômicas entre países. Embora os investimentos externos ainda não tenham retomado os patamares pré-crise de 2008, os relatórios informativos mais recentes e as perspectivas de médio prazo indicam uma recuperação integral a partir de 2018. De acordo com o World Investment Report 2016 da Conferência das Nações Unidas sobre Comércio e Desenvolvimento $\left(\mathrm{UNCTAD}^{21}\right.$ ), o fluxo anual de Investimento Externo Direto em 2015 alcançou US\$1,76 trilhão, cerca de 40\% maior do que em 2014, números que representam o maior nível desde a crise de $2008^{22}$. O mencionado report, no entanto, salienta que "parte do crescimento em IED deveu-se a reconfigurações empresariais. Essas transações geralmente envolvem grandes movimentos nos balanços de pagamentos, mas com pouca mudança nas operações reais. Descontando essas reconfigurações empresariais de larga escala, nota-se um

\footnotetext{
${ }^{21}$ Sigla em inglês para United Nations Conference on Trade and Development.

${ }^{22} \mathrm{O}$ montante ainda se encontra 10\% abaixo do pico histórico, em 2007.
} 
crescimento ao redor de $15 \%$ em fluxos globais de IED”23. Segundo o mesmo documento, espera-se que o ano de 2016, registre uma queda dos fluxos de investimentos externos de 10 a $15 \%$, com uma retomada de crescimento em 2017 e a superação da barreira de US\$1,8 trilhão em 2018.

O Brasil continua sendo um dos principais receptores de IED, no entanto, tem baixa representatividade como país investidor (VEIGA; RIOS, 2014, p. 66), principalmente quando se tem em conta o tamanho de sua economia (COLLINS, 2013, p. 25). Baumann e Gonçalves (2015, p. 192) salientam que a economia brasileira se caracteriza por "extraordinário desequilíbrio de estoque" de investimentos internacionais ${ }^{24}$. Por sua vez, Veiga e Iglesias (2002, p. 369) sustentam que "os investimentos no exterior das empresas brasileiras são relativamente baixos, especialmente quando comparados com empresas coreanas ou de outros países do Sudeste asiático ou com alguns países latino-americanos". Os rankings abaixo apresentados, extraídos de relatório da Conferência das Nações Unidas sobre Comércio e Desenvolvimento (UNCTAD ${ }^{25}$, na sigla em inglês) mostram os vinte primeiros países que mais recebem e os que mais realizam IED.

\footnotetext{
${ }^{23}$ No original: "Part of the growth in FDI was due to corporate reconfigurations. These transactions often involve large movements in the balance of payments but little change in actual operations. Discounting these large-scale corporate reconfigurations implies a more moderate increase of around 15 per cent in global FDI flows". (p. 10)

${ }^{24}$ A diferença entre o ativo externo total de um país e os seu passivo externo total é denominada pelos autores de "Posição de Investimento Internacional (PII)". Baumann e Gonçalves indicam que, em 2011, o Brasil detinha a $4^{\mathrm{a}}$ PPI mais negativa do mundo, atrás somente de dos Estados Unidos (centro do sistema monetário internacional), da Espanha (a experimentar grave desestabilização macroeconômica), e da Austrália.
}

${ }^{25}$ United Nations Conference on Trade and Development. 
Figura 1: Top 20 Economias receptoras, 2014 e 2015 (em bilhões de dólares)

\begin{tabular}{|c|c|c|}
\hline United States (3) & 107 & 380 \\
\hline Hong Kong, China (2) & $114^{175}$ & \\
\hline China (1) & 136 & \\
\hline Ireland (11) & $31 \quad 101$ & \\
\hline Netherland (8) & $52^{33}$ & \\
\hline Switzerland (38) & 769 & \\
\hline Singapore (5) & 65 & \\
\hline Brazil (4) & 65 & \\
\hline Canada (6) & 49 & \\
\hline India (10) & $35^{4}$ & \\
\hline France (20) & $15^{43}$ & \\
\hline United Kingdom (7) & 40 & \\
\hline Germany (98) & 132 & \\
\hline Belgium (189ф) & 31 & \\
\hline Mexico (13) & $\begin{array}{l}30 \\
26\end{array}$ & \\
\hline Luxembourg (23) & $12^{5}$ & \\
\hline Australia (9) & 2240 & \\
\hline Italy (14) & 30 & \\
\hline Chile (17) & 20 & \\
\hline Turkey (22) & $\frac{17}{12}$ & 2014 \\
\hline
\end{tabular}

(x) 2014 ranking

Fonte: Unctad, FDI/MNE Database (www.unctad.org/fdistatistics)
Figura 2: Top 20 Economias investidoras, 2014 e 2015 (em bilhões de dólares)

\begin{tabular}{|c|c|c|}
\hline United States (1) & 217 & 300 \\
\hline Japan (4) & 1129 & \\
\hline China (3) & $\frac{128}{123}$ & \\
\hline Netherlands (7) & $56 \quad 113$ & \\
\hline Ireland (9) & $43 \quad 102$ & \\
\hline Germany (5) & 9406 & \\
\hline Switzerland $(153-b$ & 70 & \\
\hline Canada (8) & 567 & \\
\hline Hong Kong, China (2) & $55-125$ & \\
\hline Luxembourg (15) & 239 & \\
\hline Belgium (32) & 539 & \\
\hline Singapore (11) & 35 & \\
\hline France (10) & 35 & \\
\hline Spain (12) & 35 & \\
\hline Republic of Korea (13) & 28 & \\
\hline Italy (14) & 29 & \\
\hline Russian Federation (6) & 2764 & \\
\hline Sweden (22) & $9^{24}$ & \\
\hline Norway (16) & 18 & \\
\hline Chile (19) & $\frac{16}{12}$ & \\
\hline
\end{tabular}

(x) 2014 ranking

Fonte: Unctad, FDI/MNE Database (www.unctad.org/fdistatistics) 
Como se vê, o Brasil saiu da $4^{\mathrm{a}}$ posição em 2014 para a $8^{\mathrm{a}}$ em 2015 como receptor de IED. Já a ausência do país na lista dos 20 maiores investidores é indicativa da baixa internacionalização das empresas brasileiras. $\mathrm{O}$ forte crescimento de $38 \%$ de investimentos brasileiros diretos em 2015 esconde uma relevante queda de investimentos em equity ${ }^{26}$ no exterior. $\mathrm{O}$ aumento percentual não teria ocorrido sem a redução da reversão de investimento pelas afiliadas brasileiras no exterior, a fim de aliviar as dívidas adquiridas em dólar - e agravadas em razão da forte desvalorização cambial. Além disso, os números brasileiros acabam maquiados por análises mais abrangentes de países emergentes (MEDEIROS, 2010, p. 21), como no caso dos BRICS, os quais, em conjunto, responderam por apenas $1 \%$ dos fluxos mundiais de investimentos ao exterior em 2002 para, dez anos depois, alcançar 9\% (CALDERÓN, 2014, p. 1). Os maiores responsáveis do aumento nesse período, no entanto, foram China (54\%) e Rússia (40\%), respectivamente.

\section{Figura 3: Estoque de Investimento Direto dos BRICS e sua participação no estoque mundial de investimentos diretos (em U\$ Bilhões e em percentual)}

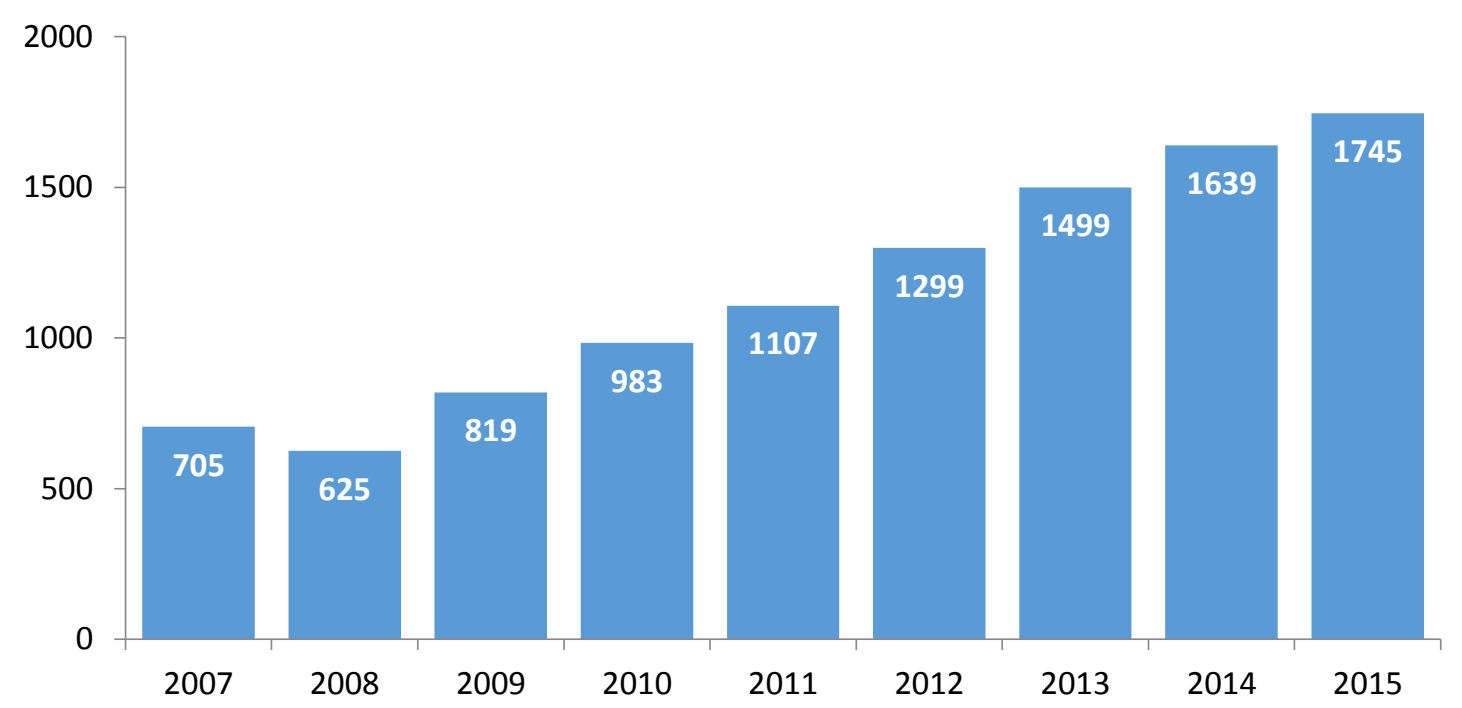

Fonte: Unctad, FDI/MNE Database (www.unctad.org/fdistatistics)

\footnotetext{
26 Em conformidade com o Glossary of Tax Terms da OCDE (disponível em http://www.oecd.org/ctp/glossaryoftaxterms.htm\#E) e para os fins deste trabalho, definiremos equity como o direito de propriedade por parte de acionistas em uma determinada sociedade. Assim, quando um investidor adquire, por exemplo, $20 \%$ das ações de uma dada empresa, diz-se que ele faz investimento em equity, porque esse direito lhe confere determinado poder de controle ou influência sobre as decisões da mencionada empresa.
} 
Em que pesem os números relativamente tímidos de investimentos brasileiros no exterior, é preciso ressalvar que o histórico recente demonstra um crescimento substantivo de investimentos diretos. Segundo as estatísticas econômicas dos capitais brasileiros no exterior, divuldadas pelo Banco Central do Brasil $(\mathrm{BCB})^{27}$, a partir dos anos 2000, o estoque de investimento Brasileiros Diretos saiu de um patamar de quase US\$ 50 bilhões para alcançar aproximadamente US\$ 300 bilhões, crescimento com taxa média nominal de 12,3\% ao ano. Mesmo quando descontada a inflação do dólar no período (33,90\%), o crescimento continua robusto, ao nível de 10,3\%. Pedro da Motta Veiga e Sandra Ríos (2014, p. 66) salientam que movimentos de internacionalizaçção de empresas brasileiras existem desde meados dos anos 1960, mas o processo vivenciado nos anos 2000 se distingue por sua densidade e diversidade, “em termos de número de empresas e setores envovidos, bem como de destino dos investimentos". Analisando os ciclos históricos de investimentos brasileiros, os mesmos autores pontuam que o Brasil, em 1990, respondia por $2 \%$ dos estoques globais de investimentos no exterior e $28 \%$ dos estoques dos países em desenvolvimento, mas essa participação caiu para $0,63 \%$ e 5,5\% em 2005, respectivamente (2014, p. 67).

Apesar da redução de 3,8\% do Produto Interno Bruto (PIB) em 2015 em comparação ao ano-base 2014, prevê-se que, no médio prazo, a reestruturação econômica permita a continuação da expansão das empresas brasileiras fora do território nacional, o que poderá possibilitar a desconcentração da carteira, já que, segundo relatório do Banco Central do Brasil sobre capitais brasileiros no exterior (BCB, 2015, p. 2), 59\% dos ativos relacionados à participação no capital são detidos por residentes que possuem acima de US\$ 1 bilhão investidos no exterior, grupo constituído por apenas 33 declarantes. O mesmo relatório expõe a outra face da moeda, identificando 11.309 investidores possuidores de menos de US\$ 10 milhões, os quais representam vultosos $88,5 \%$ do número de declarantes, mas apenas US $\$ 18,4$ bilhões - ou 7,1\% - do total declarado para o estoque de IBD - participação no capital, cerca de $7,1 \%$ do total declarado.

\footnotetext{
${ }^{27}$ Disponível em http://www4.bcb.gov.br/rex/cbe/port/cbe.asp. Acesso em 10.12.2016
} 
Figura 4: Estoque de Investimentos Brasileiros Diretos 2001-2015 (em US\$ milhões)

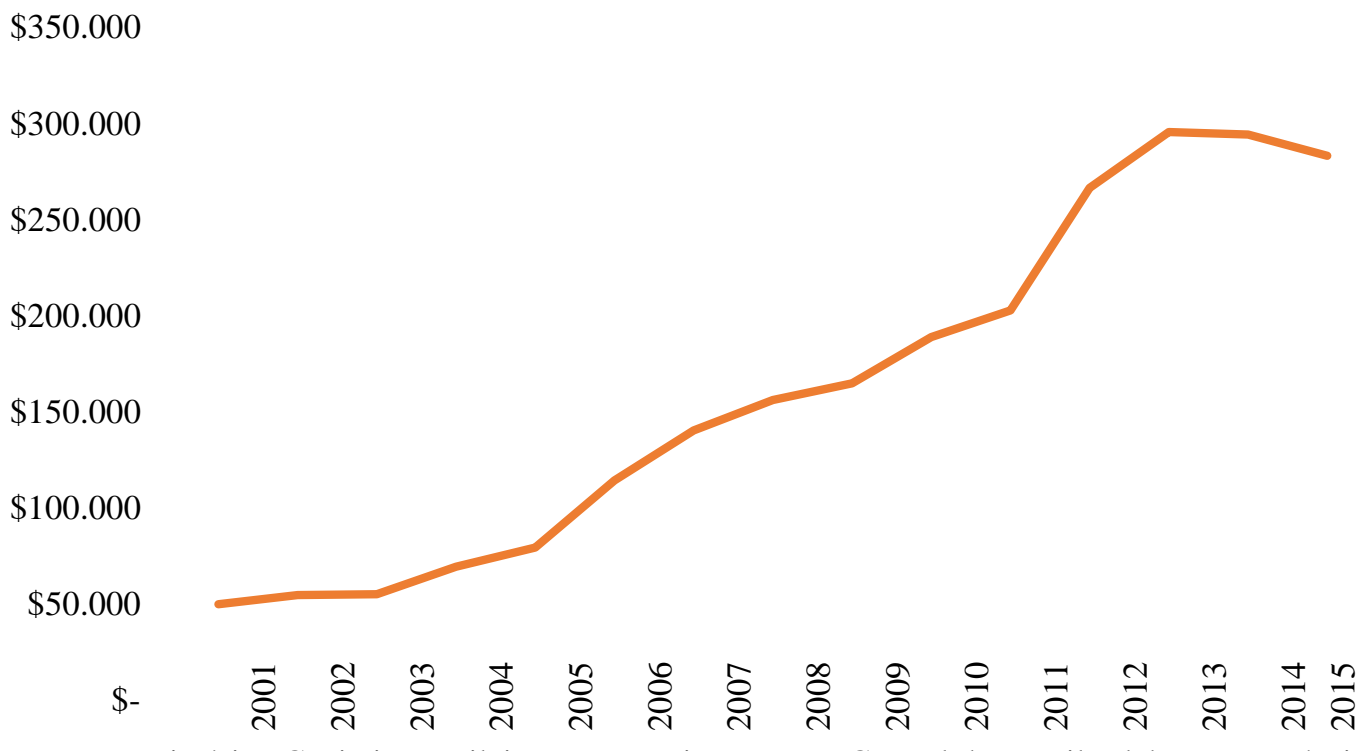

Fonte: Histórico Capitais Brasileiros no Exterior - Banco Central do Brasil. Elaboração própria

É certo que aferir o grau de internacionalização das empresas brasileiras apenas pelos valores referentes aos ativos mantidos no exterior é uma medida questionada por parte da literatura. Resende, Almeida e Ramsey (2010, p. 98) sustentam a importância de outras variáveis, como o número de empregados em outros países e as vendas externas. Para os fins deste trabalho, será utilizado o primeiro parâmetro, dada a ligação direta com a mensuração do seguro. Como se verá mais adiante, o número de empregados ou o montante de vendas externas não são variáveis contabilizadas em um cálculo atuarial dessa natureza. Por uma ou outra métrica, todavia, é inegável que o crescimento da internacionalização de empresas brasileiras nos últimos quinze anos é expressivo.

A confrontação dos dados faz o analista do tema levantar a seguinte dúvida: os números cresceram em razão da atuação do governo brasileiro ou apesar da falta de atuação do governo brasileiro? A resposta entre opções de branco ou preto parece situar-se mais em algum tom de cinza. Nesse caso, as evidências sobre o histórico de programas governamentais e a própria percepção do setor industrial indica que a atuação governamental para fomentar investimentos brasileiros no exterior foi muito aquém do esperado, principalmente quando se leva em consideração a robusta rede desenvolvida para estimular o caminho inverso, ou seja, a atração de investimentos estrangeiros ao Brasil. Pesquisa realizada pela Fundação Dom Cabral (2015, p. 69) demonstra alto apetite das empresas consultadas para ampliar investimentos no exterior. Aproximadamente $69 \%$ das empresas consultadas aumentaram 
investimentos no mercado internacional. Essa estratégia é especialmente importante em um período de dificuldades político-econômicas por que passa o Brasil:

Figura 5: Mudança nas estratégias das empresas frente ao atual contexto político-econômico brasileiro.

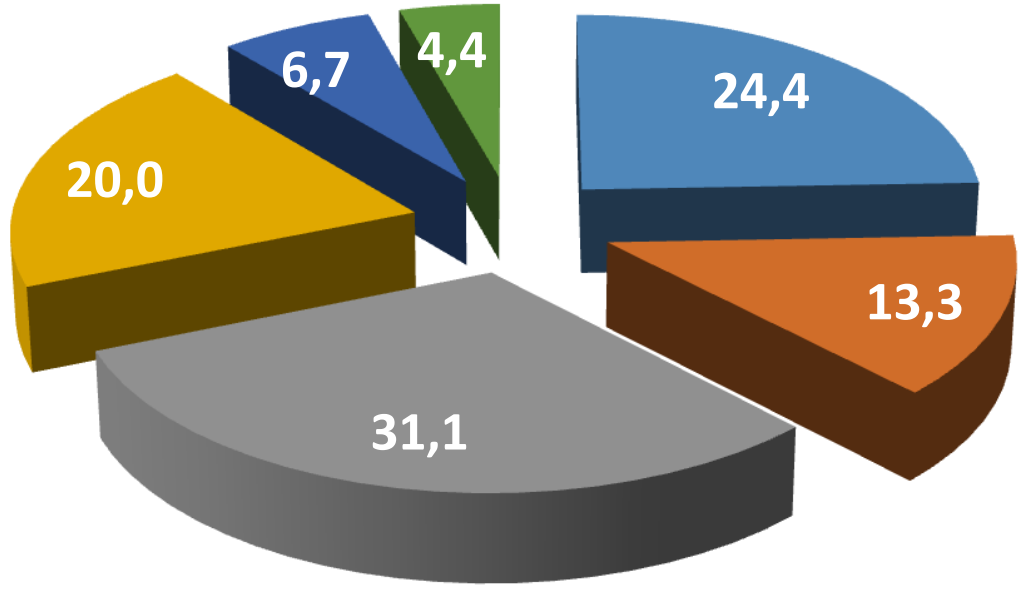

Fonte: Ranking FDC das Multinacionais Brasileiras 2015.
- A empresa ampliou os investimentos no mercado internacional e no mercado doméstico

A empresa ampliou os investimentos no mercado internacional e reduziu os investimentos no mercado doméstico

A emprea ampliou os investimentos no mercado internacional e manteve sua estratégia no mercado doméstico

A empresa reduziu os investimentos no mercado internacional e no mercado doméstico

- A empresa reduziu os investimentos no mercado internacional e ampliou os investimentos no mercado doméstico

- A empresa reduziu os investimentos no mercado internacional e manteve sua estratégia no mercado doméstico

Em que pese a o desejo de investir por parte dos industriais brasileiros, o sentimento geral desse setor é no sentido de que ainda faltam diretrizes governamentais claras de fomento à internacionalização das empresas nacionais. Este é o tom do relatório internacional da indústria elaborado pela Confederação Nacional da Indústria (CNI, 2016, p. 23):

Os investimentos de empresas brasileiras no exterior apresentaram, a partir do início do século, crescimento significativo, que levou o estoque de capitais brasileiros no exterior a ultrapassar US\$ 300 bilhões em 2014. No entanto, o investimento brasileiro no exterior, nos últimos anos, tem sido volátil e abaixo das demais economias emergentes.

Em grande medida, isso reflete o fato de que, de modo geral, as políticas vigentes no Brasil incentivam a atração de investimentos externos, mas desincentivam a internacionalização,via investimentos, das empresas brasileiras. 
Como destaca Andrade (2008, p. 143) o Brasil mantém verdadeiro sistema federal de atração de investimentos, por considerar o tema uma Política de Estado, transcendente a mandatos políticos ou direcionamentos governamentais de uma ou outra inclinação (BARRETO, 1999). Talvez o principal marco jurídico moderno para fincar esse entendimento tenha sido a Emenda Constitucional no 06/1995, que revogou o artigo 171 da Constituição Federal. Após a entrada em vigor da emenda, a Carta de 1988 deixou de diferenciar "empresa brasileira" e "empresa brasileira de capital nacional".

No âmbito governamental, Andrade (2008) recapitula a existência de Grupo de Trabalho criado pela Portaria $\mathrm{MP}^{28}$ n. 8 , de 20 de janeiro de 2000, cujo resultado levou à criação da Rede Brasileira de Promoção de Investimentos - INVESTE BRASIL, sob o formato de agência, que tinha por escopo a busca e manutenção do investimento estrangeiro direto no país (idem, p. 144). A agência teve fim em meados de 2004, mas foi substituída por um sistema federal, criada pelo Decreto de 30 de agosto do mesmo ano ${ }^{29}$.

O Decreto acima mencionado instituiria a Comissão de Incentivo aos Investimentos Produtivos Privados no País, no âmbito da Casa Civil da Presidência da República. Conforme disposto em seu art. $1^{\circ}$, a finalidade precípua da Comissão seria a seguinte:

fomentar e incentivar o desenvolvimento de investimentos no Brasil,
mediante ações que atraiam, facilitem e informem investidores privados
nacionais e estrangeiros a realizarem investimentos produtivos, em especial
nas áreas e setores estratégicos para o desenvolvimento econômico
sustentável, que promovam novo padrão de crescimento pautado na visão de
investimentos de longo prazo com inclusão social e justiça ambiental.

Somada à Comissão, Andrade (2008, p. 144) cita a atuação da APEX-Brasil, criada em 1997 no âmbito do Sebrae Nacional, mas reformulada por meio do Decreto 4.584/03. Interessante notar que, entre as atribuições da APEX-Brasil apresentadas em seu sítio oficial, estão a internacionalização de negócios brasileiros e a atração de investimentos externos para o país. A internacionalização de empresas brasileiras, contudo, se dá por meio das exportações de produtos de serviços, não havendo qualquer referência expressa ao investimento brasileiro no exterior:

\footnotetext{
28 Então Ministério do Planejamento, Orçamento e Gestão, atualmente denominado como Ministério do Planejamento, Desenvolvimento e Gestão.

${ }^{29}$ O mencionado decreto, publicado na p. 2 da Seção 1 do DOU de 31/08/2004, não tem número específico.
} 
A Agência Brasileira de Promoção de Exportações e Investimentos (ApexBrasil) atua para promover os produtos e serviços brasileiros no exterior e atrair investimentos estrangeiros para setores estratégicos da economia brasileira.

A Agência realiza ações diversificadas de promoção comercial que visam promover as exportações e valorizar os produtos e serviços brasileiros no exterior, como missões prospectivas e comerciais, rodadas de negócios, apoio à participação de empresas brasileiras em grandes feiras internacionais, visitas de compradores estrangeiros e formadores de opinião para conhecer a estrutura produtiva brasileira entre outras plataformas de negócios que também têm por objetivo fortalecer a marca Brasil.

A Apex-Brasil coordena os esforços de atração de investimentos estrangeiros diretos (IED) para o Brasil com foco em setores estratégicos para o desenvolvimento da competitividade das empresas brasileiras e do país ${ }^{30}$.

Menciona-se também a atuação da Rede Nacional de Informações sobre o Investimento (RENAI), gerida pela Coordenação-Geral de Programas para o Desenvolvimento Industrial e Investimentos da Secretaria do Desenvolvimento e Competitividade Industrial do MDIC. A RENAI busca concretizar as oportunidades de investimento estrangeiro no país, por meio, basicamente, de três ações: a) fornecer ao potencial investidor informações úteis no processo de tomada de decisão sobre investimentos no Brasil; b) apoiar as estruturas federal e estaduais no desenvolvimento de atividades voltadas à promoção de inversões produtivas; c) articular medidas de facilitação dos investimentos no País. ${ }^{31}$

Por fim, em uma parceria do Ministério das Relações Exteriores (MRE), do Ministério da Indústria, Comércio Exterior e Serviços (MDIC) e do Ministério da Agricultura, Pecuária e Abastecimento (MAPA), o governo federal mantém o portal http://www.investexportbrasil.gov.br/, o qual, entre outras iniciativas relacionadas ao comércio exterior, proporciona um extenso leque de arquivos e informações relacionadas às oportunidades de investimento no Brasil e possibilidades de incentivos, abrangendo alívios fiscais, linhas de financiamento e acordos para evitar dupla tributação.

A participação ativa do Estado, por meio de políticas públicas voltadas à internacionalização das empresas constituídas sob sua jurisdição, tende a gerar resultados superiores em comparação a países sem políticas públicas tão claras (Coelho; Júnior, 2012, p. 51). Apesar disso, ao contrário do que ocorre com a atração de investimentos estrangeiros para o Brasil, do lado da promoção dos investimentos brasileiros no exterior, não é possível dizer que há verdadeiro sistema federal, instituído como Política de Estado, com capacidade

\footnotetext{
${ }^{30}$ http://www.apexbrasil.com.br/quem-somos. Acesso em 15/12/2016.

${ }^{31}$ http://investimentos.mdic.gov.br/conteudo/index/item/22. Acesso em 15/12/2016.
} 
duradoura, independentemente do governo do momento. Aparentemente, não há, no governo brasileiro, um entendimento claro e resoluto a respeito das ligações entre estratégias oficiais de promoção à recepção e ao envio de investimentos diretos. Barreiras regulatórias são elencadas por Collins (2013, p. 25) como um dos motivos pelos quais o Brasil apresenta números ainda aquém de suas possibilidades no investimento ao exterior. Outra possibilidade por ele levantada seria o fato de que as empresas brasileiras encontram no mercado doméstico espaço suficiente para seus bens e serviços, o que enfraqueceria um dos principais fatores propulsores à expansão no estrangeiro. De todo modo, empresas brasileiras já transnacionalizadas costumam indicar que o investimento direto no exterior propicia uma estratégia essencial de negócios para atingir grau de competição com as empresas globais operando dentro do Brasil (WHEATLEY, 2010, p.1).

Concordando com Wheatley, Collins (2013, pp. 26-28) cita três razões para a necessidade de internacionalização das empresas brasileiras. Em primeiro lugar, a partir da década de 1990 as empresas brasileiras tiveram que confrontar a árdua concorrência de novos entrantes no mercado nacional, em decorrência da privatização de estatais brasileiras a grupos globais. Essa pressão de fora para dentro teria gerado uma necessidade de sobrevivência, e expandir a outros países seria uma estratégia natural para diluir a concentração do mercado. $\mathrm{O}$ aumento da competição no próprio mercado é lembrado por Sette Fortes (2011, p. 29) como uma das principais características do processo de globalização.

Um segundo fator para a internacionalização seria uma pressão interna, decorrente das condições ainda insatisfatórias existentes no Brasil. A infraestrutura pobre (portos, rodovias, ferrovias etc.) e dificuldades regulatórias como, por exemplo, a imposição de quotas de produção ou o complexo e pesado sistema tributário levariam empresas mais dinâmicas a expandir para os vizinhos no Mercado Comum do Sul (Mercosul) ou mesmo para países fora do continente, numa estratégia mais global $^{32}$.

Uma terceira motivação seria o ímpeto de adquirir tecnologia e conhecimento no exterior. O capital humano e tecnológico brasileiro ainda é comparativamente fraco,

\footnotetext{
32 "O último balanço da siderúrgica Gerdau é um exemplo eloquente de um dos maiores problemas das empresas brasileiras. Segundo o relatório, divulgado na semana passada, a Gerdau gerou no ano passado uma riqueza de $\mathrm{R} \$ 2,9$ bilhões no exterior, principalmente nos Estados Unidos. Dessa quantia, teve de separar R \$672,8 milhões, ou $23,2 \%$, para o pagamento de impostos. Já no Brasil a empresa obteve uma receita de R 7,4 bilhões. E pagou R \$ 3,1 bilhões ao Fisco. Foram 47,6\% de toda a riqueza que gerou aqui, mais que o dobro da taxa lá fora. Essa carga de impostos acarreta uma grande diferença na distribuição de riqueza da Gerdau. No exterior, a empresa pagou R \$ 1,2 bilhão a seus fornecedores e funcionários. Trata-se de 41,9\% do resultado financeiro. Aqui, a empresa pagou R\$ 1 bilhão aos colaboradores - apenas $16,1 \%$ do resultado. Ou seja: lá fora, os principais beneficiários do lucro da empresa são os trabalhadores. Aqui, é o governo". In: É para ir embora? Revista Época. Disponível em http://revistaepoca.globo.com/Revista/Epoca/0,EDR74906-6012,00.html. Acesso em $17 / 12 / 2016$.
} 
particularmente em áreas como engenharia, essencial para setores como o de energia ou de alta tecnologia. Se a precária preparação do trabalhador brasileiro é um problema para empresas globais que aqui decidem investir, não é demais pensar que também seja uma razão para que as empresas locais busquem se expandir para além do território. Ao identificar fases no processo de internacionalização das empresas brasileiras nas últimas décadas, Fortes (2011, p. 31) relata que, nos anos 1990, empresas brasileiras começaram a seguir um fluxo inverso ao tradicional, abrindo filiais em países desenvolvidos a fim de realizar "transferência tecnológica reversa", um processo consistente em aprender na filial para ensinar à matriz conhecimentos de toda ordem.

As pressões citadas, apesar de impactantes no círculo corporativo, aparentemente não foram historicamente canalizadas para o ambiente governamental. Até a recentíssima criação do Comitê Nacional de Investimentos (Coninv) - sobre o qual se falará mais $\operatorname{adiante}^{33}$-, não se viam esferas do Estado oficialmente tocadas pelo contexto atual e articuladas para, de maneira organizada, fomentar a internacionalização de empresas nacionais. A estratégia ainda precária quanto aos investimentos brasileiros no exterior gera não apenas a perda de oportunidades, mas, antes, um desequilíbrio de competitividade das empresas nacionais, porquanto elas são diretamente influenciadas pelas políticas claras de atração de investimento estrangeiro. Não se critica o fomento ao recebimento de capital externo. Esse incentivo organizado, contudo, representa fonte de pressão às empresas nacionais. Se, por um lado, as empresas brasileiras que sofrem concorrência internacional "dentro de casa" são obrigadas a melhorar seus produtos e serviços, por outro, essa melhora tende a ocorrer em caráter reativo, e as empresas têm pouco incentivo governamental para aventuras empresariais fora do Brasil. Uma vez que as estratégias empresariais são limitadas pelo espaço de atuação das empresas, muitas vezes se veem empresas globais - com estratégias globais - competindo, com absoluta vantagem, com empresas nacionais - com estratégias mais limitadas.

É preciso lembrar que políticas públicas de estímulo do investimento de firmas domésticas no exterior tendem a encontrar dificuldade de apoio no próprio governo e em parte do setor privado. Iglesias e Veiga (2002, p. 429), apontam que a posição crítica a esse tipo de política é reforçada pelo fato de que

(...) os efeitos diretos (número de empregos não criados no país de origem da firma internacionalizada ou montante da saída de capital) têm maior objetividade quando comparados com a menor definição dos efeitos indiretos (criação de empregos e investimento na rede de fornecedores domésticos da firma internacionalizada, criação de novas exportações de peças e bens intermediários ou ingressos de lucros e dividendos.

\footnotetext{
${ }^{33}$ Conferir subseção 1.2 .3 abaixo
} 
Em que pesem as posições em contrário (e a vantagem de argumentação objetiva em que tais posições se amparam), o entendimento deste autor é o de que o governo brasileiro precisa, sim, ter uma estratégia robusta de promoção de investimentos brasileiros no exterior. Essa estratégia passaria, necessariamente, por três ações, as quais deveriam ser pensadas de forma conjunta: a) o fomento à assinatura de tradados de investimento, com vistas a convergir entendimentos sobre o tema e diminuir custos de transação entre Estados de forma preventiva; b) o aumento de iniciativas de financiamento à internacionalização no exterior, o que significaria um avanço em relação ao financiamento à exportação; c) mecanismos nacionais de garantias, com o objetivo de compensar, de maneira tempestiva e eficaz, investidores nacionais que sofram medidas governamentais do Estado receptor tendentes a afetar o investimento. Como se mostrará a seguir, os dois primeiros pontos são objeto de iniciativas ainda insuficientes por parte do Estado, enquanto o último (objeto central desta dissertação) nunca saiu do papel. Essas evidências reforçam a percepção de que reformas são necessárias, a fim de remover obstáculos internos que limitam a competitividade externa (MEDEIROS, 2010, p. 21).

\subsubsection{Os tratados de investimento}

O percurso atualmente seguido pelo governo brasileiro em relação aos tratados de investimento sofreu uma mudança de $180^{\circ}$ em relação aos primeiros passos tomados na segunda metade da década de 1990. Naquela década, o Brasil chegou a assinar quatorze tratados bilaterais de investimento, chamados de Acordos Bilaterais de Promoção e Proteção Recíproca de Investimentos (APPI), na grande maioria dos casos com países desenvolvidos, o que reforçava a lógica de um país tradicionalmente importador de capital (COLLINS, 2013, p. 37). Além disso, no âmbito do Mercosul foram firmados dois protocolos: a) o de Colônia (1993), a tratar de investimentos entre os países membros da comunidade; b) e o de Buenos Aires (1994), a cuidar dos investimentos realizados entre o Mercosul e países extrabloco. Foram contrapartes do Brasil nos mencionados acordos bilaterais os seguintes países: Alemanha, Chile, Cuba, Dinamarca, Bélgica e Luxemburgo, Itália, Finlândia, República da Coreia, França, Portugal, Reino Unido, Países Baixos, Suíça e Venezuela.

Dos quatorze acordos, nenhum chegou a entrar em vigor. Na realidade, apenas seis chegaram a tramitar perante o Congresso Nacional, etapa necessária à ratificação de tratados assinados pela República Federativa do Brasil. Após a criação de um Grupo de Trabalho 
interministerial em 2002, o governo federal concluiu que a existência de problemas envolvendo os tratados demandava a retirada de todos eles da pauta de internacionalização de nossa economia.

Medrado e Daudt (2015; p. 1) elencam três razões para a não entrada em vigor dos APPIs:

(i) a cláusula de livre transferência de recursos dos APPIs estava redigida de forma pouco favorável aos interesses brasileiros. O Brasil já tinha obrigações assumidas perante o FMI e a OMC relativas à livre transferência de recursos, e a adoção de novas cláusulas no âmbito dos APPIs poderia limitar sua autonomia para regular transferências e pagamentos internacionais;

(ii) a cláusula de indenização por expropriação dos APPIs também causava preocupação, pois conferia tratamento mais favorável ao investidor estrangeiro do que ao doméstico (indenizações seriam pagas de imediato, em moeda conversível e livremente transferível aos investidores estrangeiros; paralelamente, os arts. 182 e 184 da Constituição Federal previam hipóteses de pagamento não imediato, na forma de títulos da dívida pública ou da reforma agrária) e porque a proteção contra "medidas equivalentes à expropriação" era considerada demasiadamente ampla, o que poderia prejudicar a capacidade ordenatória/regulatória do Estado;

(iii) o mecanismo de solução de controvérsias autorizava o investidor estrangeiro a acionar diretamente (em uma arbitragem internacional) o Brasil, com vistas a discutir o adimplemento de obrigações assumidas no tratado. Havia temor de um número muito robusto de ações, e a experiência da Argentina, demandada em inúmeras arbitragens perante o ICSID, reforçava a necessidade de menor exposição do Estado brasileiro.

O entrave político à assinatura de tratados bilaterais de investimento levou o país a uma posição relativa extremamente desfavorável no que diz respeito à proteção jurídica de capitais externos, situação que certamente prejudicou tanto o envio quanto o recebimento de investimentos, na medida em que o objetivo principal desses acordos - promover e proteger investimentos estrangeiros (PANZINI; BIASUTTI, 2015, p. 60) impacta as duas direções do fluxo. Tabela formulada já em 2012 por Daniel Castelan (2012, p. 78) demonstrava a parca articulação nacional no tema, quando comparada aos seus vizinhos sul-americanos: 
Tabela 1: América do Sul - Acordos Bilaterais de Investimento

\begin{tabular}{lcccccc}
\hline \multirow{2}{*}{\multicolumn{1}{c}{ País }} & $\begin{array}{c}\text { Estoque de IED } \\
\text { \% do PIB }\end{array}$ & \multicolumn{5}{c}{ Acordos Bilaterais de Investimento } \\
\cline { 3 - 6 } & Média 1990-2011 & Número & \% & Número & \% & Percentual de \\
\cline { 3 - 6 } & 20,8 & 58 & 20,57 & 55 & 23,71 & 95 \\
\hline Argentinaticação & Nún \\
Chile & 55,17 & 51 & 18,09 & 39 & 16,81 & 76 \\
Peru & 17,24 & 32 & 11,35 & 30 & 12,93 & 94 \\
Uruguai & 14,9 & 30 & 10,64 & 25 & 10,78 & 83 \\
Venezuela & 22,07 & 26 & 9,22 & 24 & 10,34 & 92 \\
Paraguai & 13,64 & 24 & 8,51 & 21 & 9,05 & 88 \\
Bolívia & 40,29 & 22 & 7,80 & 20 & 8,62 & 91 \\
Equador & 23,64 & 18 & 6,38 & 16 & 6,90 & 89 \\
Brasil & 17,13 & 14 & 4,96 & 0 & 0,00 & 0 \\
Colômbia & 17,91 & 7 & 2,48 & 2 & 0,86 & 29 \\
\hline Total & & $\mathbf{2 8 2}$ & $\mathbf{1 0 0 , 0 0}$ & $\mathbf{2 3 2}$ & $\mathbf{1 0 0 , 0 0}$ & \\
\hline
\end{tabular}

Fontes: UNCTADSTAT (2012) para estoque de IED e UNCTAD (2012b) para acordos. Elaboração: Castelan (2012)

A reorientação do governo brasileiro em relação a tratados de investimento tem-se consolidado desde o segundo mandato do governo Dilma, quando começaram a ser assinados os chamados Acordos de Cooperação e Facilitação de Investimentos (ACFI). Destaca-se o fato de que o Brasil foi o país que mais fechou acordos de investimentos no ano de $2015^{34}$. Dos 20 acordos bilaterais assinados nesse ano e monitorados pela UNCTAD, o Brasil foi parte em seis deles (com Angola, Chile, Colômbia, Malaui, México e Moçambique), enquanto a República da Coreia e o Japão foram partes em quatro, e a China em três. Recentemente, o Brasil tem avançado negociações para a assinatura de mais dois tratados bilaterais de investimentos, desta vez com a Índia e com a Jordânia. Os países com os quais o Brasil tem buscado selar acordos bilaterais sobre investimentos estão relacionados na tabela 2 abaixo:

\footnotetext{
${ }^{34}$ Hirsch contabilizava, já em 2012, cerca de 2.600 tratados bilaterais em matéria de relações de investimento, sem levar em consideração outros tratados de natureza regional ou multilateral que também contêm regras sobre investimentos estrangeiros (2012, p. 10)
} 
Tabela 2: ACFIs negociados/assinados até 2016

\begin{tabular}{l|l}
\hline Contraparte & Ano de Assinatura \\
\hline Angola & 2015 \\
\hline Chile & 2015 \\
\hline Colômbia & 2015 \\
\hline Malaui & 2015 \\
\hline México & 2015 \\
\hline Moçambique & 2015 \\
\hline Peru & 2016 \\
\hline Índia & Ainda não assinado \\
\hline Jordânia & Ainda não assinado \\
\hline
\end{tabular}

Fonte: SECEX/MDIC

A nova estratégia nacional confere especial atenção à promoção e à facilitação de investimentos, bem como à prevenção de disputas e a alternativas de arbitragem, em substituição a regras tradicionais de "investment protection" e de "investor-State dispute settlement" (ISDS) (MEDRADO; DAUDT, 2015).

A ênfase do Brasil no estabelecimento de acordos de cooperação e facilitação de investimentos com outros países em desenvolvimento - em cujos territórios as empresas brasileiras são competitivas - é respaldada pela significativa participação dessas nações como receptoras de IED, contabilizando US\$ 765 bilhões em 2015, 9\% a mais que 2014.

A nova estratégia diplomática brasileira ainda demanda tempo de maturação para avaliação de resultados, afinal de contas o conjunto de acordos ainda é muito pequeno, nenhum texto entrou em vigor e, o que é mais importante, a partir do momento em que os tratados passarem a viger, suas cláusulas ainda terão de ser submetidas a "testes de fogo". Assim, em que pese a profícua produção de acordos nos últimos anos, é cedo para julgar a iniciativa bem-sucedida.

Além da falta de "experiência normativa" dos textos, é preciso destacar outro problema, decorrente do fato de que o conceito chave de todos esses tratados já assinados - o que a palavra "investimento" significa, para fins de alcance da norma - não é unívoco. Como se verá na tabela 3 abaixo, o tratado firmado entre Brasil e Angola, por exemplo, prevê que as definições de investimentos deverão ser reguladas pelos ordenamentos jurídicos internos de cada país. Outros tratados, como os assinados com Chile, Colômbia, México e Moçambique, fazem referência expressa ao significado da palavra investimento, e vão além, ao explicarem, em artigos separados, o que o conceito de investimento abrange e o que ele não abrange: 


\begin{tabular}{|c|c|c|c|}
\hline Contraparte & Conceito de Investimento & Investimento inclui & Investimento não inclui \\
\hline Angola & $\begin{array}{l}\text { as definições } \\
\text { sobre investimento, } \\
\text { investidor e outras definições } \\
\text { inerentes a esta matéria serão } \\
\text { reguladas pelos respectivos } \\
\text { ordenamentos jurídicos das Partes }\end{array}$ & - & - \\
\hline Chile & $\begin{array}{l}\text { investimento direto, ou seja, todo } \\
\text { ativo de propriedade ou controlado, } \\
\text { direta ou indiretamente, por um } \\
\text { investidor de uma Parte, estabelecido } \\
\text { ou adquirido de conformidade com o } \\
\text { ordenamento jurídico da outra Parte, } \\
\text { no território dessa outra Parte, que } \\
\text { permita exercer a propriedade, o } \\
\text { controle ou um grau significativo de } \\
\text { influência sobre a gestão da } \\
\text { produção de bens ou da prestação de } \\
\text { serviços no território do Estado } \\
\text { Anfitrião }\end{array}$ & $\begin{array}{l}\text { uma } \\
\text { (b) ações, capital ou outros tipos de participação no patrimônio ou capital } \\
\text { social de umpresa; } \\
\text { (c) títulos, debêntures, empréstimos ou outros instrumentos de dívida de uma } \\
\text { empresa, independentemente do prazo de vencimento inicial, mas não } \\
\text { incluindo, no caso do Brasil, um instrumento de dívida ou um empréstimo a } \\
\text { uma empresa do Estado que não desenvolva atividades econômicas em } \\
\text { condições de mercado e, no caso do Chile, um instrumento de dívida emitido } \\
\text { por uma empresa do Estado ou um empréstimo a uma empresa do Estado; } \\
\text { (d) direitos contratuais, incluindo contratos de "turnkey", construção, gestão, } \\
\text { produção, de concessão, de partilha de receitas e outros contratos similares; } \\
\text { (e) licenças, autorizações, permissões e direitos similares outorgados de } \\
\text { conformidade com a legislação interna do Estado Anfitrião; } \\
\text { (f) direitos de propriedade intelectual tal como definidos ou referidos no } \\
\text { Acordo sobre Aspectos dos Direitos de Propriedade Intelectual relacionados } \\
\text { ao Comércio da Organização Mundial do Comércio (TRIPS). } \\
\text { (g) direitos de propriedade, tangíveis ou intangíveis, móveis ou imóveis, e } \\
\text { quaisquer outros direitos reais, como hipoteca, penhor, usufruto e direitos } \\
\text { similares; }\end{array}$ & $\begin{array}{l}\text { (a) as operações de dívida pública; } \\
\text { (b) uma ordem ou sentença emitida em uma ação } \\
\text { judicial ou } \\
\text { (c) os investimentos de portfólio; e } \\
\text { (d) as reclamações pecuniárias decorrentes } \\
\text { exclusivamente de contratos comerciais para a } \\
\text { venda de bens ou serviços por parte de um } \\
\text { investidor no território de uma Parte a um nacional } \\
\text { ou uma empresa no território da outra Parte ou a } \\
\text { concessão de crédito no âmbito de uma transação } \\
\text { comercial. }\end{array}$ \\
\hline Colômbia & $\begin{array}{l}\text { investimento direto de um investidor } \\
\text { de uma Parte, estabelecido ou } \\
\text { adquirido de conformidade com as } \\
\text { leis e regulamentos da outra Parte, } \\
\text { que permita exercer, direta ou } \\
\text { indiretamente, controle ou grau } \\
\text { significativo de influência sobre a } \\
\text { gestão da produção de bens ou da } \\
\text { prestação de serviços no território da } \\
\text { outra Parte. }\end{array}$ & 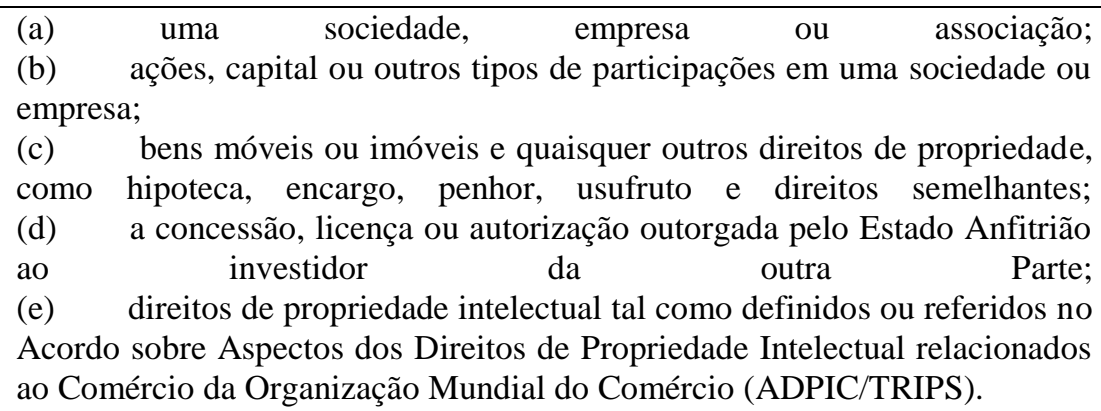 & $\begin{array}{l}\text { (a) as operações de dívida pública; } \\
\text { (b) os investimentos de portfólio; e } \\
\text { (c) os direitos de crédito decorrentes } \\
\text { exclusivamente de contratos comerciais para a } \\
\text { venda de bens ou serviços por parte de um } \\
\text { investidor no território de uma Parte a um nacional } \\
\text { ou uma empresa no território da outra Parte ou a } \\
\text { concessão de crédito no âmbito de uma transação } \\
\text { comercial. }\end{array}$ \\
\hline
\end{tabular}




\begin{tabular}{|c|c|c|c|}
\hline Malaui & $\begin{array}{l}\text { qualquer tipo de bem ou direito } \\
\text { pertencentes ou controlados direta ou } \\
\text { indiretamente por um investidor de } \\
\text { uma das Partes no território da outra } \\
\text { Parte, com o propósito de estabelecer } \\
\text { relações econômicas duradoras, e } \\
\text { destinado à produção de bens e } \\
\text { serviços }\end{array}$ & $\begin{array}{l}\text { a) Quotas, ações, e outra participação acionária ("Equity") e instrumentos } \\
\text { da dívida da empresa ou de outra empresa; } \\
\text { b) Empréstimos }\end{array}$ & $\begin{array}{l}\text { a) Títulos de dívida emitidos por um governo ou } \\
\text { empréstimos concedidos a um governo; } \\
\text { b) Investimentos de portfólio; e } \\
\text { c) Créditos pecuniários decorrentes } \\
\text { exclusivamente de contratos comerciais para a } \\
\text { venda de bens e de serviços por um nacional ou } \\
\text { empresa no território de uma Parte para uma } \\
\text { empresa no território de outra Parte, ou concessão } \\
\text { de crédito em conexão com uma transação } \\
\text { comercial, ou qualquer outra reivindicação } \\
\text { pecuniária que não envolva as situaçôes } \\
\text { estabelecidas nas alíneas (i) - (v) acima. }\end{array}$ \\
\hline México & $\begin{array}{l}\text { Investimento direto, ou seja, todo } \\
\text { ativo de propriedade ou controlado, } \\
\text { direta ou indiretamente, por um } \\
\text { investidor de uma Parte, estabelecido } \\
\text { ou adquirido de conformidade com o } \\
\text { ordenamento jurídico de outra Parte, } \\
\text { no território dessa outra Parte, que } \\
\text { permita exercer a propriedade, o } \\
\text { controle ou um grau significativo de } \\
\text { influência sobre a gestão da } \\
\text { produção de bens ou da prestação de } \\
\text { serviços no território do Estado } \\
\text { anfitrião }\end{array}$ & 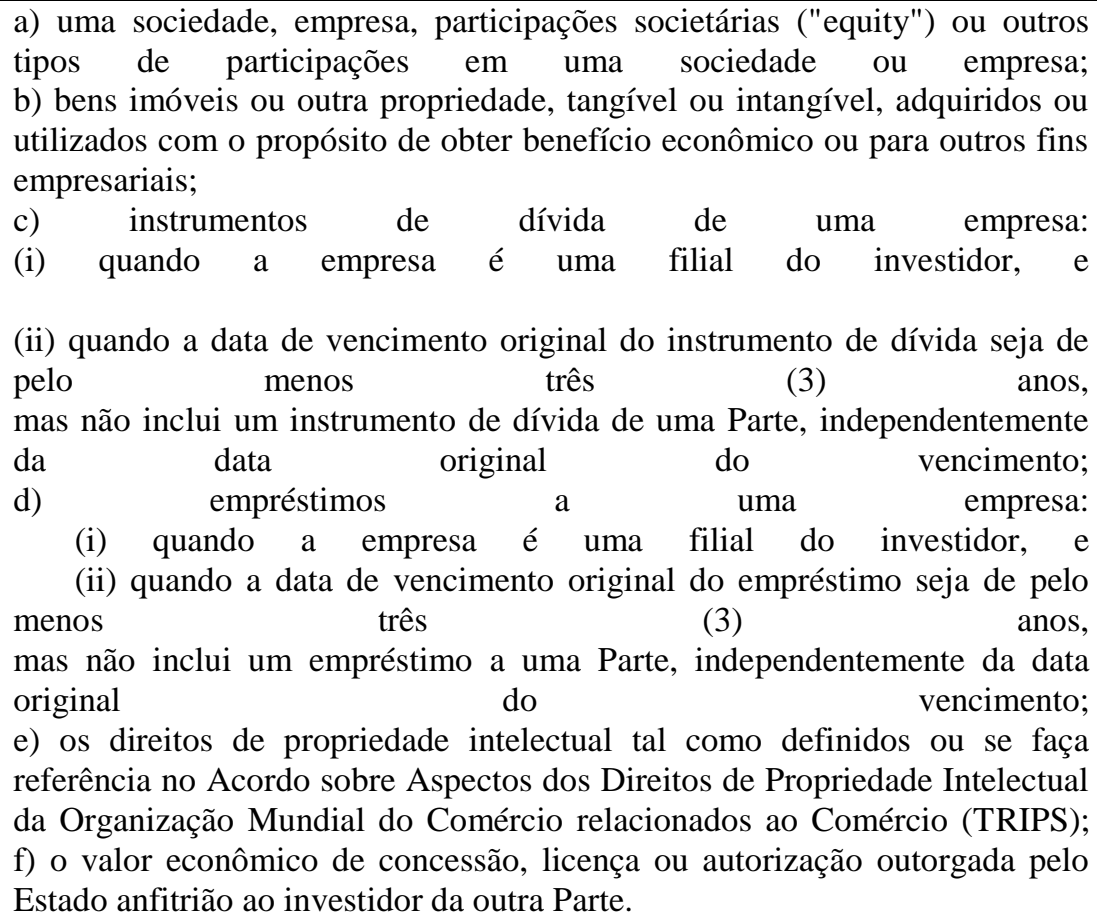 & 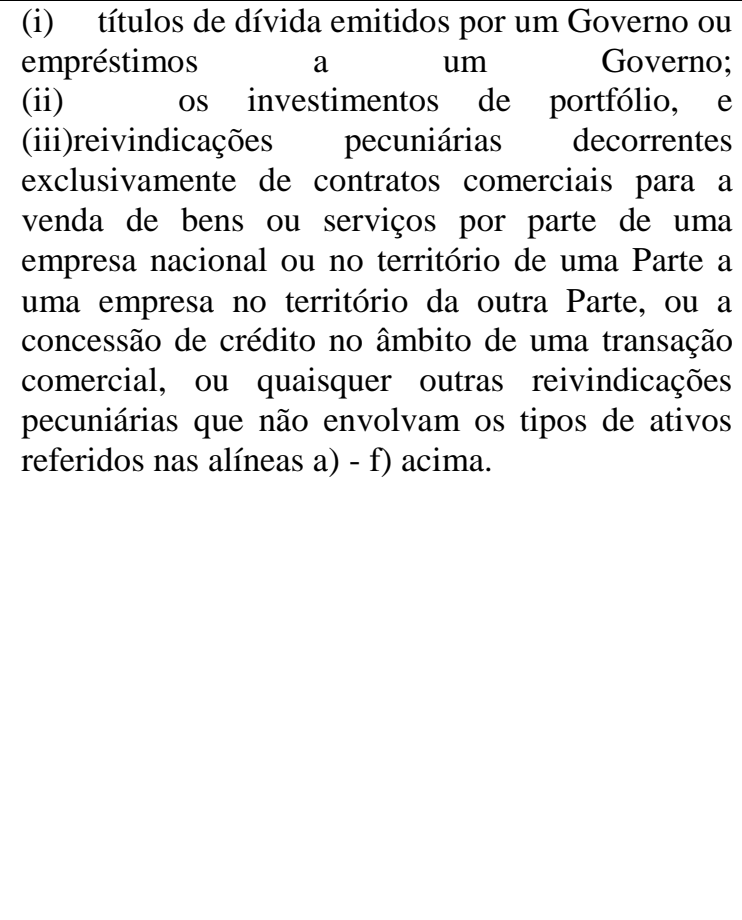 \\
\hline
\end{tabular}




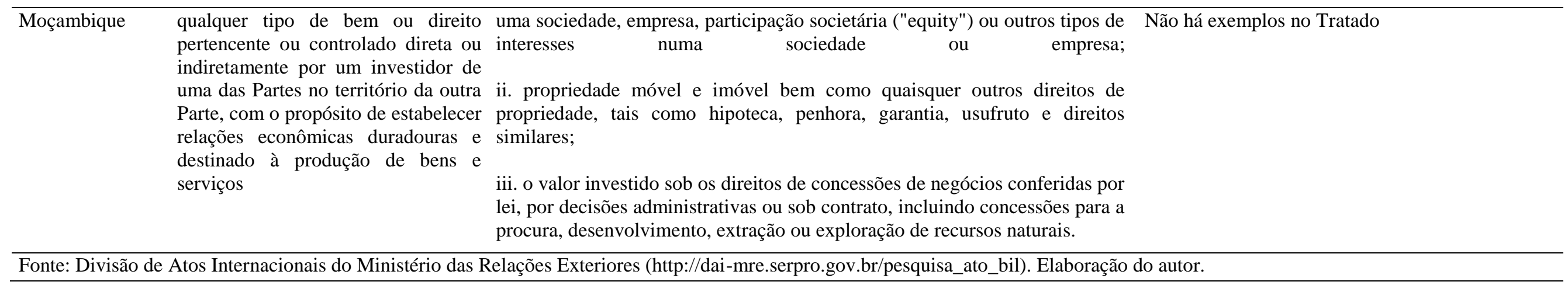


Em relação aos protocolos de Colônia e Buenos Aires, assinados no âmbito do Mercosul, eles também não chegaram a entrar em vigor. Atualmente, discute-se a possibilidade de que um novo Protocolo seja firmado como marco de cooperação e facilitação de investimentos intrabloco. Em discurso ${ }^{35}$ datado de 21 de dezembro de 2015 por ocasião da XLIX Reunião de Cúpula do Mercosul, a então presidente Dilma Roussef indicou a proposta brasileira de dotar o bloco com um novo marco facilitador para investimentos:

Para meu governo, o fortalecimento do Mercosul passa necessariamente pela adoção de formas mais ágeis de cooperação comercial e de construção de cadeias produtivas intrarregionais. Devemos resolver a questão das assimetrias regionais, e isso só será possível com a maior cooperação comercial e, sobretudo, com a construção dessas cadeias.

A economia contemporânea, ela é dinâmica. Nós precisamos adaptarmos às mudanças sob pena de comprometer a competitividade de nossas empresas e a atratividade de nossas economias para os investidores. Foi com esse espírito que propusemos, recentemente, dotar o bloco de um protocolo de cooperação e facilitação de investimentos. Esses investimentos trarão de volta o crescimento e os empregos e permitirão que superemos as dificuldades econômica atuais $^{36}$.

A presidente fazia referência à iniciativa brasileira de apresentar ao bloco, em setembro daquele ano, duas propostas seguintes a respeito de investimentos: a) mandato negociador; b) protocolo de cooperação e facilitação de investimentos. A sugestão da delegação brasileira constou na Ata n ${ }^{\circ}$ 03/2015 do Grupo Mercado Comum ${ }^{37}$ :

\subsection{Propuesta de Protocolo de Cooperación y Facilitación de Inversiones Intra-MERCOSUR}

La Delegación de Brasil circuló por Nota DMSUL/24/2015, propuesta de Proyecto de Resolución "Mandato Negociador para Protocolo de Cooperación y Facilitación de Inversiones Intra - MERCOSUR" (Anexo XVIII - RESERVADO - MERCOSUR/XCIX GMC/DT $\mathbf{N}^{\circ}$ 30/15).

Asimismo, la Delegación de Brasil presentó en este GMC el documento "Protocolo de Cooperación y de Facilitación de

\footnotetext{
35 Disponível em http://www2.planalto.gov.br/acompanhe-o-planalto/discursos/discursos-dapresidenta/discurso-da-presidenta-da-republica-dilma-rousseff-durante-a-xlix-cupula-dos-estados-partesdo-mercosul-e-estados-associados-assuncao-paraguai. Acesso em 22.12.2016.

${ }^{36}$ Discurso da Presidenta da República, Dilma Rousseff, por ocasião da XLIX Cúpula dos Estados Partes do MERCOSUL e Estados Associados - Assunção, 21 de dezembro de 2015. Disponível em http://www.itamaraty.gov.br/pt-BR/component/content/article?id=12776. Acesso em 20.12.2016.
}

37 Disponível em http://www.mercosur.int/innovaportal/v/387/2/innova.front/busqueda-de-normativa. Acesso em 20.12.2016. 
Inversiones Intra - MERCOSUR", que consta como Anexo XVIII (RESERVADO - MERCOSUR/XCIX GMC/DT $\mathbf{N}^{\circ}$ 30/15)

El GMC instruyó al SGT $\mathrm{N}^{\circ} 12$ "Inversiones" a analizar en su próxima reunión los mencionados documentos. Al respecto, la PPPT informó que convocará próximamente a dicho Subgrupo.

Apesar de os textos das propostas acima descritas constarem como reservados, é possível encontrar na rede mundial de computadores ${ }^{38}$ minuta de resolução estabelecendo um mandato negociador. A mencionada proposta estabelecia a seguinte estrutura básica:

“1. Objetivo - promover a cooperação entre os Estados Partes com o objetivo de facilitar e incentivar o investimento intrarregional, por meio do estabelecimento de marco institucional para facilitar os investimentos, de mecanismos para a mitigação de riscos e a prevenção de conflitos, e de uma agenda de cooperação.

1. Ấmbito de Aplicação - o Protocolo aplicar-se-á a todos os investimentos estrangeiros diretos realizados antes ou depois de sua entrada em vigor.

2. Obrigações de Não Discriminação - o Protocolo conterá disciplinas sobre Tratamento Nacional e Cláusula da Nação Mais Favorecida.

3. Expropriação Direta - o texto conterá disciplinas sobre Expropriação Direta e não utilizará o conceito de expropriação indireta, que pode limitar a formulação de políticas públicas.

4. Transparência - Os Estados Partes deverão assegurar a transparência de todas as medidas que afetem os investimentos e que sejam administradas de maneira razoável, objetiva e imparcial, em conformidade com seus respectivos ordenamentos jurídicos.

5. Transferências - Os Estados Partes permitirão a livre transferência dos fundos relacionados com o investimento, sem demora, em moeda de livre uso ou de acordo com a taxa de câmbio em vigor na data da transferência.

6. Responsabilidade Social Corporativa - Os investidores dos Estados Partes e seus investimentos se esforçarão para atingir o mais alto nível possível de contribuição ao desenvolvimento sustentável do Estado anfitrião e das comunidades locais onde se instalem, por meio da adoção de um alto grau de práticas socialmente responsáveis, $\mathrm{cm}$ base nos princípios e normas voluntárias contidos no texto do Protocolo.

\section{Governança Institucional}

a) Pontos Focais ou "ombudsmen" - os Estados Partes designarão um Ponto Focal Nacional ou "Ombudsman", que terá como função principal dar apoio aos investidores da outra Parte em seu território.

b) Comitê conjunto - o SGT 12 atuará como Comitê Conjunto para a Administração do Protocolo.

8. Troca de Informações entre as Partes - Os Estados Partes trocarão informações sobre oportunidades de negócio, procedimentos

38 XCIX Reunión Ordinaria Del Grupo Mercado Común - Acta no 03/15. Anexo XVIII. Reservado. Asunción, 22 y 23 de setiembre de 2015. Disponível em GMC_2015_ACTA03_ANE18_ES_DT30 _ProtocoloCoopFacilitaci\#U00f3nInversionesMERCOSUR_R.pdf. Acesso em 20.12.2016. 
e requisitos para investimentos, em especial por meio do SGT 12 e de seus Pontos Focais Nacionais.

9. Prevenção de Controvérsias - Os pontos Focais ou "Ombudsmen" atuarão articuladamente entre si e com o SGT 12 de forma a prevenir, gerir e resolver as controvérsias entre as Partes.

10. Solução de Controvérsias entre as Partes - Caso a controvérsia não seja resolvida pelo sistema de prevenção de controvérsias, os Estados Partes poderão discutir o tema através do sistema de solução de controvérsias do Protocolo de Olivos.

11. Agenda para Maior Cooperação e Facilitação de Investimentos - O SGT 12 desenvolverá e discutirá sob o protocolo uma Agenda para Maior Cooperação e Facilitação de Investimentos nos temas relevantes à promoção e ao incremento dos investimentos intrarregionais.

\subsubsection{Iniciativas de financiamento à internacionalização}

O apoio governamental aos investimentos brasileiros no exterior por meio de mecanismos facilitadores de financiamento configura pilar crucial no processo de expansão da economia brasileira para além das nossas fronteiras (COLLINS, 2013, p. 29). A percepção da importância desse pilar não é nova no ambiente acadêmico. Analisando pesquisa de 1995 realizada pelo BNDES com 30 grandes grupos exportadores, Roberto Magno Iglesias e Pedro da Motta Veiga (2002, p. 404) relatam que mais de $66 \%$ das firmas apontaram como o principal problema para a internacionalização a dificuldade de obter financiamento no Brasil para a unidade no exterior.

As dificuldades para financiamentos de longo prazo e de maior risco não dizem respeito somente ao tema dos investimentos no exterior. Shapiro (2010b), em livro derivado de sua tese de doutorado, trata do da importância de bancos públicos, como o BNDES, no processo de viabilização do financiamento de longo prazo em economias em desenvolvimento. Por sua vez, tratando especificamente do financiamento público às exportações brasileiras, Ana Rachel Freitas da Silva (2014) apresenta argumentos que se coadunam com os de Schapiro. Segundo Ana Rachel, o financiamento público à exportação, sob a ótica desenvolvimentista, permite o direcionamento de projetos e o seu acompanhamento pelo poder público.

Com efeito, assim como o financiamento é crucial para o desenvolvimento de fatores econômicos domésticos, ele também tem função essencial no processo de internacionalização sustentável de uma economia, seja por meio das exportações, seja por meio dos investimentos no exterior. A expansão do financiamento às exportações 
brasileiras, por exemplo, poderia gerar uma maior diversificação da pauta exportadora. Como ressalta Medeiros (2010, p. 21) o aumento das exportações requer uma "mudança do perfil da pauta de exportação, com aumento da presença de bens de capital, de manufaturados com maior tecnologia e valor agregado e inclusão de extensa lista de serviços comercializados no comércio mundial". Note-se que essa reformulação do perfil internacional passa pela maturação de produções de longo prazo e ciclos econômicos mais extensos do que o tradicionalmente exigido para uma pauta de exportações que se concentrem no setor primário, cujos produtos são, em geral, pagos à vista ou em curto prazo.

A racionalidade acima apresentada pode ser estendida também para o estudo dos investimentos externos. Transnacionalizar uma empresa exige longo prazo de maturação de um investimento, maior conhecimento sobre o mercado estrangeiro e, muitas vezes, conformidade com outro modelo regulatório. Isso exige um compromisso financeiro mais conservador, uma vez que os resultados de curto prazo podem ser deficitários. Pensar e planejar com um horizonte mais largo é, portanto, fundamental.

Basicamente, o funding pode ser de quatro tipos: a) próprio, quando a empresa aloca recursos seus no longo prazo, concedendo crédito (prazo) para um comprador de bens ou serviços ou atuando sem expectativa de retorno no curto prazo, em relação aos investimentos; b) privado via mercado de capitais, por meio de alocações pulverizadas como emissão de debêntures ou a emissão de ações; c) privada via sistema bancário, com a realização de operações de empréstimo; d) público, normalmente por meio de fundos de financiamento ou por linhas próprias de bancos públicos, mecanismos pelos quais a empresa geralmente tem acesso a recursos menos onerosos. Aproveitando-nos dos subsídios teóricos de Schapiro - com os quais concordamos -, é de se concluir que ações relevantes de internacionalização econômica via investimentos também seriam, no Brasil, fortemente influenciadas por diretrizes do governo brasileiro, amparado em recursos públicos, por meio de bancos de desenvolvimento ${ }^{39}$.

No âmbito das exportações de bens e serviços, é possível citar dois modelos públicos relevantes de financiamento no Brasil. O primeiro é o Programa de

\footnotetext{
${ }^{39}$ Quanto ao financiamento de investimentos de longo prazo, Mattos $(2015$, p. 333) destaca que a relevância do papel dos bancos estatais se deve ao "baixo nível da poupança doméstica como fonte de recursos mais barata (não referenciada na Taxa SELIC - Sistema Especial de Liquidação e de Custódia) para empréstimos por meio dos bancos privados, permanecendo os recursos subsidiados do Tesouro e do Fundo de Amparo ao Trabalhador - FAT (referenciados na Taxa de Juros de Longo Prazo - TJLP), repassados especialmente ao Banco Nacional de Desenvolvimento Econômico e Social - BNDES e à caixa Econômica Federal - CEF, como as principais fontes de recursos para empréstimos de longo prazo".
} 
Financiamento às Exportações de financiamento direto ou equalização (consistente no pagamento, pelo Tesouro Nacional à instituição financeira, da diferença a maior entre os encargos pactuados com o tomador e os custos da captação dos recursos) (MEDEIROS, 2010, p. 23; CASTRO, 2015, p. 61). O Proex aloca recursos do Tesouro Nacional, devidamente inscritos no Orçamento Geral da União. Instituído em 1991, atualmente o programa é disciplinado pela Lei $n^{\circ}$ 10.184/2001. O segundo é o BNDES ExIm, linha de financiamento do BNDES para diferentes modalidades a seguir listadas ${ }^{40}$ :

i) Pré-embarque: financiamento à produção nacional de máquinas, equipamentos, bens de consumo etc;

ii) Pré-embarque Empresa Âncora: financiamento de exportações efetuadas por trading companies, empresas comerciais exportadoras e outras empresas que participem da cadeia produtiva e que adquiram a produção de outras empresas para exportação;

iii) Pré-embarque Empresa Inovadora: financiamento a empresas que produzam bens de capital e serviços de tecnologia da informação (TI) desenvolvidos no Brasil;

iv) Pós-Embarque bens: financiamento à exportação de bens nacionais e serviços a eles associados.

v) Pós-embarque Serviços: financiamento à exportação de serviços nacionais (construção civil, engenharia, tecnologia da informação etc), com bens de fabricação nacional utilizados e/ou incorporados ao empreendimento;

vi) Exim Aeronaves: financiamento à exportação de aeronaves e motores aeronáuticos civis, bem como partes, peças e serviços associados - todos de fabricação nacional;

vii) Exim Automático: financiamento à exportação de bens e serviços nacionais, por intermédio de agente financeiro no exterior, que aprova a operação de crédito (papel semelhante ao do agente financeiro no Brasil, em operações indiretas da empresa com o BNDES).

Já no tocante à internacionalização de empresas, não há nenhum fundo governamental com as mesmas características do Proex, por exemplo. No âmbito do

40 Retirado de: http://www.bndes.gov.br/wps/portal/site/home/financiamento/produto/BNDESExim/!ut/p/z1/04_iUlDg4tKPAFJABpSA0fpReYllmemJJZn5eYk5-

hH6kVFm8V4WPs4eliYGPu5GwWYGj gGBhsYeQaFGFqGm15gjQj9IBPw64iA6oAqh1P6kUZFvs66fpRBYklGbqZeWn5-hFOfi6uwbquFZm5-gXZ UZEAskhAcQ!!/. Acesso em 21.12.2016. 
BNDES, é possível identificar práticas de uma política voltada à projeção internacional de empresas nacionais além das exportações de bens e serviços: muito presente nos últimos anos do governo Lula e nos primeiros anos do governo Dilma, essa política ficou conhecida como "Campeões Nacionais" 41 .

Ana Alem e Claudio Cavalcanti (2005, p. 69) relatam que, até 2002, o BNDES - cuja atuação era então disciplinada pelo Decreto nº 104, de 22 de abril de 1991 - não dispunha de uma política específica para impulsionar investimentos brasileiros no exterior e promover a internacionalização das empresas nacionais. A partir de meados daquele ano, a diretoria do Banco lançou recomendações, e o Estatuto do BNDES foi alterado. O novo Estatuto ${ }^{42}$ autorizava, em seu art. $9^{\circ}$, II, que o BNDES poderia "financiar investimentos realizados por empresas de capital nacional no exterior, sempre que contribuam para promover exportações". Veja-se que a autorização estava diretamente vinculada ao aumento de exportações. Após nova alteração do Estatuto realizada em $2007^{43}$, o Estatuto do BNDES passou a prever, no mesmo dispositivo, que o banco poderá "financiar a aquisição de ativos e investimentos realizados por empresas de capital nacional no exterior, desde que contribuam para o desenvolvimento econômico e social do País". A linha de financiamento voltava-se à formação de conglomerados que pudessem competir em escala global, e isso incluía o financiamento à aquisição de concorrentes no exterior, abertura de filiais em outros países ou de empresas voltadas à produção de insumos para a matriz.

Ao tratarem da política do BNDES de apoio à internacionalização de empresas brasileiras, Baumann e Gonçalves (2015, p. 208) escrevem que

\begin{abstract}
[...] há que se destacar as linhas de financiamento do BNDES de apoio à internacionalização da produção do setor de serviços (inclusive, a construção civil). OS recursos do BNDES (BNDESPar, BNDES Participações S.A.) também são usados para fortalecer a base de capital de empresas que têm estratégias de internacionalização. As principais empresas que se beneficiaram dos recursos do BNDESPar estão em diferentes segmentos, com destaque para empresas na agroindústria, construção e bens de capital (Hiratuka e Sarti, 2010, p. 286-287). Vale mencionar que, no ranking das empresas brasileiras com investimento no exterior elaborado pela Fundação Dom Cabral (2014, p. 33), a JBS (setor de alimentos) é a primeira colocada em todo o período de 2010-2013. Em 2009, o BNDESPar tinha participação de 13\% no capital da JBS (Hirotuka e SArti, 2010, tabela 13). A Marfrig (também do setor de alimentos) é outra empresa com elevado índice de
\end{abstract}

\footnotetext{
41 A respeito do debate entre política industrial e defesa da concorrência, com foco no tema dos “campeões nacionais", conferir Carvalho e Castro (2012).

${ }^{42}$ Decreto $\mathrm{n}^{\mathrm{o}} 4.418$, de 11 de outubro de 2002.

${ }^{43}$ Por força do Decreto $n^{\circ} 6.322$, de 21 de dezembro de 2007.
} 
transnacionalidade (quinta posição do ranking da Fundação Dom Cabral) e o BNDESPar tem 14,6\% do capital dessa empresa.

Em 2013, contudo, a política do BNDES de apoio à internacionalização de empresas foi severamente reduzida, no auge da crise política gerada pela Comissão Parlamentar de Inquérito (CPI do BNDES), em razão do baixo apelo que a política recebia dos formadores de opinião e, o que é mais importante, devido à escassez de recursos que passou a prejudicar as operações do banco, uma situação maior que envolvia as relações da instituição financeira com programas do Tesouro Nacional. Assim, atualmente, tampouco é possível afirmar a existência de uma política forte, pelo lado do financiamento, voltada à internacionalização de empresas.

1.2.3. O Comitê Nacional de Investimentos (Coninv): uma nova política para a recepção e o envio?

Um fato relevante a merecer menção, ainda que não tenha produzido resultados concretos até a finalização do presente trabalho, foi a criação, no âmbito da Câmara de Comércio Exterior (CAMEX), do chamado Comitê Nacional de Investimentos (Coninv), por força da Resolução $\mathrm{n}^{\circ}$ 124, de 13 de dezembro de 2016. De acordo com suas regras regimentais, o Coninv foi criado com a finalidade de "formular propostas e recomendações à CAMEX voltadas ao fomento e à facilitação de Investimentos Estrangeiros Diretos (IED) no País e de Investimentos Brasileiros Diretos no Exterior (IBDE)" (art. $\left.1^{\circ}\right)$. Compõem o Comitê as seguintes autoridades (art. $\left.2^{\circ}\right)$ :

I - Secretário-Geral das Relações Exteriores;

II - Secretário-Executivo da Casa Civil da Presidência da República;

III - Secretário-Executivo do Ministério da Fazenda;

IV - Secretário-Executivo do Ministério da Agricultura, Pecuária e Abastecimento;

V - Secretário-Executivo do Ministério da Indústria, Comércio Exterior e Serviços;

VI - Secretário-Executivo do Ministério do Planejamento, Desenvolvimento e Gestão;

VII - Secretário-Executivo Adjunto do Programa de Parcerias de Investimentos da Presidência da República; e

VIII - Secretário-Executivo da CAMEX. 
Além dos membros acima referidos, o Presidente da Agência Brasileira de Promoção de Exportações (APEX-Brasil) e o Presidente da Agência Brasileira de Desenvolvimento Industrial (ABDI) também participam do Comitê, mas sem direito a voto.

Embora o Coninv tenha dedicado, em seu regimento interno, atenção equivalente à atração de investimentos externos e à promoção de investimentos brasileiros no exterior, não houve, ainda, qualquer resultado em termos de propostas de políticas públicas para o tema dos investimentos diretos. Não há referência expressa à matéria de seguros e garantias. Todavia, no que concerne à matéria de fomento e facilitação de investimentos brasileiros diretos no exterior (art. $7^{\circ}$ ), estão entre as competências do Coninv as seguintes ações: submeter à consideração da CAMEX propostas de estratégia brasileira de apoio à internacionalização de empresas brasileiras; submeter à consideração da CAMEX propostas de políticas, medidas e mecanismos de apoio à internacionalização das empresas brasileiras; manter diálogo com o setor privado, inclusive por intermédio do Conselho Consultivo do Setor Privado (Conex), sobre a internacionalização das empresas brasileiras, em especial no que tange às suas expectativas, necessidades e dificuldades na matéria; e propor à CAMEX medidas de coordenação de iniciativas dos diversos órgãos governamentais que tenham competência na dinâmica de internacionalização de empresas, bem como acompanhar sua execução. De todo modo, avaliações sobre o Coninv demandarão tempo de operacionalização do Comitê, a fim de que se possa concluir sobre a efetividade da atuação deste órgão. 


\section{REGIMES DE SEGURO DE INVESTIMENTO}

$2.1 \mathrm{O}$ seguro de investimento

Segundo Zlatko Salcic (2014, p. 98), o seguro de investimento para investimentos externos "é o seguro ou a garantia fornecida a um investidor contra perdas de investimento realizado em um país estrangeiro, resultantes de expropriação, nacionalização, guerra, motins, distúrbios civis, restrições sobre transferências de fundos e outros eventos políticos"44. Há vários tipos de seguro de investimento, mas o objeto deste trabalho cinge-se aos investimentos voltados à cobertura de riscos políticos, conhecidos como Political Risk Insurance, ou simplesmente PRI.

No âmbito do Banco Mundial, a agência responsável por prover essa espécie de garantia é a Multilateral Investment Guarantee Fund (MIGA), que define risco político da seguinte forma:

Political risks are associated with government actions with deny or restrict the right of an investor/owner i) to use or benefit from his/her assets; or ii) which reduce the value of the firm. Political risks include war, revolutions government seizure of property and actions to restrict the movement of profits or other revenues from within a country ${ }^{45}$.

O seguro de investimento varia de país a país em relação aos prêmios cobrados, à duração do investimento e ao alcance da cobertura. Em trabalho realizado sob os auspícios da OCDE, Kathryn Gordon (2008, p. 92) realizou pesquisa qualitativa sobre as características das instituições públicas e privadas que ofereciam esse tipo de produto, e identificou padrões significativos a respeito desse tipo de seguro, em relação a outros riscos passíveis de proteção por seguro.

Segundo Gordon (2008, p. 93), um "risco segurável” (insurable risk) é um conceito que compreende três condições técnicas, a fim de garantir a lucratividade no longo prazo de quem provê o seguro: i) avaliação (assessability), consistente na necessária quantificação da probabilidade e da severidade das perdas; ii) aleatoriedade (randomness), a indicar que a frequência da ocorrência do evento deve ser imprevisível

\footnotetext{
${ }^{44}$ No original: "The ECA cover for foreign investments is insurance or a guarantee provided to an investor for a loss of investment made in a foreign country, resulting from expropriation, nationalisation, war, riots, civil disturbances, restrictions on transfer of funds and other political events".

45 Disponível em: https://www.miga.org/Documents/Glossary_of_Terms_Used_in_the_Political_Risk_ Insurance_Industry.pdf. Acesso em 10.02.2017.
} 
quando o seguro é provido, e essa mesma ocorrência deve ser independente da vontade do segurado; iii) mutualidade (mutuality), a qual significa que múltiplas pessoas expostas ao risco devem integrar uma comunidade de risco dentro da qual esse risco é dividido e diversificado.

Como exemplo, um seguro de automóvel com cobertura contra risco de incêndio respeita as três condições acima, pois, em tese: i) as empresas conseguem quantificar a frequência de carros incendiados, bem como mensurar o valor das perdas; ii) o evento não é previsível e, respeitada a boa-fé, não há razão para o segurado incendiar seu próprio veículo; iii) a companhia firma contratos com pessoas de perfis diferentes e riscos diferentes, de modo que tende ao impossível a hipótese de que todos os carros do portfólio, ou uma parcela significativa dele, sejam incendiados. As condições acima também valem para a grande maioria dos riscos que conhecemos, como o risco de acidente, de roubo/furto de veículos, de doença, de vida etc.

Os riscos políticos, por sua vez, tendem a se afastar das condições acima relacionadas. Em primeiro lugar, o país receptor dos investimentos tem participação, direta ou indireta, na ocorrência de sinistros como os citados por Salcic (2014). Além disso, a maneira como os investidores se relacionam com o Estado receptor pode ter efeito sobre a ocorrência ou não do evento segurável. Assim, investidores que tenham uma relação pouco amistosa com governos locais, regionais ou nacionais podem sofrer retaliações como rescisões arbitrárias de contratos ou embargos excessivos à execução de suas atividades. Assim, sinistros de natureza política não são eventos absolutamente involuntários De igual modo, eventos como expropriação podem ser difíceis de caracterizar, principalmente quando se trata de atos conhecidos como "expropriação indireta" ${ }^{46}$. Por fim, eventos políticos protagonizados por um país (como as guerras, por exemplo) podem levar de arrasto dezenas, centenas ou até mesmo milhares de contratos segurados.

\footnotetext{
${ }^{46}$ A chamada expropriação indireta (“creeping expropriation") consiste em uma derivação importante do conceito de expropriação. Segundo PANZINI e BIASUTTI (2015, p. 62) a expropriação indireta ocorre "quando há perda de valor do investimento ou privação do investidor de controlar sua propriedade por força de uma medida não discriminatória e que não visava o benefício do Estado". O efeito final de atos com essa natureza acaba por ser, também, expropriatório. Sornarajah $(2010$, p. 375$)$ lista dez categorias de expropriação indireta: 1) venda forçada de propriedade; 2) venda forçada de participação em um investimento; 3) medidas de nacionalização progressiva; 4) tomada de controle de um investimento; 5) indução de outrem à tomada física de propriedade; 6) falha ao prover proteção quando houver interferência na propriedade de um investidor estrangeiro; 7) decisões administrativas que cancelam licenças necessárias à atuação do investidor estrangeiro; 8) tributação exorbitante; 9) expulsão do investidor estrangeiro de maneira contrária ao direito internacional; 10) atos de ameaça, tais como congelamento de contas bancárias.
} 
Assim, a lógica diversa do regime do seguro de investimentos contra riscos políticos implica o desenvolvimento de embasamentos econômico e jurídico próprios ao regime.

\subsubsection{Histórico das ECAs}

Rodrigo de Azeredo Santos sumariza o início das operações internacionais de apoio às exportações via instrumentos garantidores do Estado (SANTOS, 2011, p. 187):

O primeiro programa de seguro e crédito à exportação foi oferecido pela Federal of Switzerland, uma empresa privada, em 1906. Treze anos mais tarde, a Grã-Bretanha lançou o primeiro programa público de crédito à exportação, em 1919. Com o sucesso dos programas suíço e inglês, vários países europeus lançaram os seus próprios programas de apoio financeiro às exportações, incluindo a Bélgica (1921), a Dinamarca (1922), Holanda (1923), Finlância (1925), Alemanha (1926), Áustria e Itália (1927), França e Espanha (1928) e a Noruega (1929). Nos anos 30, outros países estabeleceram programas de apoio financeiro às exportações, como o Japão (1930) e os EUA (1934).

Com o aumento das entidades públicas e privadas exercendo essa atividade, em 1934 foi criada a International Union of Credit and Investiment Insurers (União de Berna) para compartilharem informações e experiências na concessão de créditos à exportação.

Na década de 1950, durante a retomada do crescimento após a segunda guerra mundial, percebeu-se que a atuação governamental estava reduzindo artificialmente os preços das exportações desses países. Essa prática caracterizava subsídios às exportações, que estavam distorcendo o comércio internacional. A respeito das garantias (objeto de discussão deste trabalho), esses subsídios envolviam a cobrança de prêmios de seguro insuficientes para cobrir as perdas de longo prazo das seguradoras públicas, gerando prejuízos assumidos pelos Estados (MORAVCSIK, 1989, p. 177).

Assim, em 1963 foi estabelecido um grupo no âmbito da OCDE para discutir regras comuns sobre créditos à exportação (OECD, 2011, p. 38). Só em 1976 houve um consenso sobre essas regras, que ensejaram o Arrangement on Officially Supported Export Credits de 1978. Esse arranjo é um acordo de cavalheiros e costuma ser revisto periodicamente, sempre que houver demanda. No ano seguinte, 1979, ocorreu a Rodada Tóquio do General Agreement on Tariffs and Trade (GATT), ocasião na qual se criou a lista de subsídios proibidos e se previram dois tipos de subsídios em créditos à 
exportação: (i) cobrar prêmios insuficientes para cobrir as perdas de longo prazo; e (ii) prover financiamento com taxas inferiores ao custo de captação dos Estados e que fugissem das taxas praticadas internacionalmente.

Até a década de 1990, a concessão de créditos oficiais à exportação concentrava-se nos países desenvolvidos. Os países em desenvolvimento, no entanto, começaram a replicar essa prática para fomentar suas exportações, com a vantagem de não terem que observar as regras da OCDE no arranjo sobre créditos à exportação, justamente por não serem membros efetivos da Organização. Essa liberdade dos países em desenvolvimento foi contestada no âmbito das disputas entre Brasil e Canadá na OMC entre 1997 e $2006^{47}$ sobre o apoio às exportações do setor aeronáutico. Depois dessa disputa, ficou claro que os países não concederiam subsídios proibidos à exportação se seguissem o arranjo da OCDE.

Atualmente, a presença de ECAs no âmbito dos BRICS e outros países em desenvolvimento tem levado a uma revisão sobre as regras internacionais de crédito à exportação. A ECA chinesa, Sinosure, é hoje a maior seguradora de créditos à exportação do mundo em termos de volume de negócios, com uma exposição de USD 396,97 bilhões em 2013 - ao passo que em 2003 a exposição da empresa era de USD 5,71 bilhões.

No Brasil, assim como na maior parte dos países industrializados, o mercado segurador privado não dispõe de capacidade para absorver os riscos que advêm da integralidade dessas operações. De modo geral, as transações de longo prazo (e, por conseguinte, de valor elevado) e aquelas afetadas por riscos políticos e extraordinários costumam ser garantidas por Agências de Crédito à Exportação (ECAs), as quais muitas vezes utilizam fundos públicos. É interessante notar, contudo, que o apoio oficial brasileiro à exportação foi iniciado somente na década de 1960, com pelo menos quarenta anos de atraso em relação à primeira onda de criações de ECAs em outras partes do mundo. A Lei $\mathrm{n}^{\circ} 5.025$, de junho de 1966, criou tanto o Conselho Nacional de Comércio Exterior (CONCEX) quanto o Fundo de Financiamento à Exportação (FINEX). O FINEX deu lugar ao Programa de Financiamento às Exportações (PROEX) em 1991, programa existente até os dias atuais. A primeira lei geral sobre Seguro de

\footnotetext{
${ }^{47}$ Por disputas, compreendem-se os casos Brazil - Export Financing Programme for Aircraft (DS46), Canada - Measures Affecting the Export of Civilian Aircraft (DS70), e Canada - Export Credits and Loan Guarantees for Regional Aircraft (DS222). Para saber mais sobre os casos, conferir Daniel Roberto Pinto (2013, pp. 45-84), José Serrador Neto (2013, pp. 281-312) e Marcus Vinicius Ramalho (2013, pp. 649-668)
} 
Crédito à Exportação, por sua vez, data de $1965^{48}$, sendo depois revogada pela legislação aplicável atualmente vigente, a Lei nº 6.704/1979 (e alterações posteriores). Baumann e Gonçalves (2015, p. 131) também citam a Comissão para Concessão de Incentivos Fiscais e Programas Especiais de Exportação, chamada Befiex, criada em maio de 1972. Conforme comentam os autores (idem, p. 131),

As empresas cujos projetos eram aprovados pela comissão tinham direito a importar com redução ou isenção de tributos bens de capital e partes, peças, componentes, matérias-primas e produtos intermediários, dentro de certos limites. Esses incentivos eram cumulativos às facilidades do mecanismo de drawback e a todos os demais incentivos às exportações.

Especificamente quanto aos investimentos, a estratégia de implantação de regimes de seguros de investimentos no exterior ganhou força nos anos 1980 e 1990, em decorrência da criação de agências especializadas criadas nos países desenvolvidos. De acordo com a UNCTAD $(1999$, p. 5),

Nos anos 1980 e 1990, em um esforço para promover investimento no exterior, muitos países desenvolvidos liberalizaram seus quadros regulatórios e iniciaram programas para facilitar o investimento no exterior. Tais programas variam enormemente em estrutura e escopo, mas três áreas principais de intervenção podem ser percebidas: (1) o fornecimento de informação e de assistência técnica em apoio ao investimento no exterior; (2) regimes financeiros e incentivos fiscais; e (3) seguro e garantias de investimento. Para executar essas atividades, a maioria dos países desenvolvidos estabeleceu agências e instituições para cada um desses serviços. Em contraste, países em desenvolvimento geralmente não contam com essas agências ou têm apenas um modelo institucional mais modesto em apoio ao investimento no exterior. Eles confiam mais nos serviços fornecidos por instituições regionais e globais. (grifos nossos) ${ }^{49}$

\footnotetext{
${ }^{48}$ Lei $\mathrm{n}^{\circ} 4.678$, de 16 de junho de 1965.

${ }^{49}$ No original: "In the 1980s and 1990s, in an effort to promote outward investment, many developed countries liberalized their regulatory frameworks and launched programmes to facilitate outward investment. Such programmes vary widely in structure and scope, but three main areas of intervention can be distinguished: (1) the provision of information and technical assistance in support of outward investment; (2) financial schemes and fiscal incentives; and (3) investment insurance and guarantees. In order to carry out these activities, most developed countries have established agencies and institutions for each of these services. In contrast, developing countries often have no such agencies or have only a more modest institutional set-up in support of outward investment. They rely more on services provided by regional and global institutions".
} 
2.1.2. Embasamento econômico do seguro de investimento. O papel das ECAs e as falhas de mercado

A compreensão do fundamento econômico que justifica a atuação governamental na promoção da internacionalização dos investimentos de empresas de um determinado país exige a compreensão das chamadas Agências de Crédito à Exportação (Export Credit Agencies - ECA, no inglês), cujo surgimento remonta aos primeiros anos do século passado. Em especial, a importância de entender como funcionam as ECAs decorre do fato de que os seguros de investimento atualmente existentes no mundo ou são um produto específico dentre uma variedade maior de seguros ofertados por essas mesmas ECAs, ou são o principal objeto de promoção de uma agência própria e especializada em investimentos, mas com a mesma - ou muito similar - função de uma ECA voltada para operações de crédito.

$\mathrm{O}$ foco inicial das chamadas ECAS era o financiamento direto à exportação e o seguro de crédito à exportação. Esses serviços eram ofertados em razão da existência de "falhas de mercado". Em outras palavras, havia a percepção de que o mercado privado não detinha recursos ou o apetite necessário para financiar ou garantir operações importantes para diversos setores econômicos. Não é outra a percepção de Rodrigo Azeredo Santos. Para o diplomata brasileiro (SANTOS, 2011, p. 14), há uma "falha de mercado" no contexto do financiamento de projetos de médio e longo prazos, em razão do baixo interesse por parte do setor financeiro privado, que prefere atuar nas operações de curto prazo, sem riscos prolongados. Daí ser necessária a intervenção do setor público, "pela via nacional ou multilateral, de modo a tornar disponíveis instrumentos financeiros que viabilizem projetos de longa maturação". Por exemplo, Allen e Viscusi (1976, p. 160) indicam o montante das perdas possíveis como uma barreira importante à entrada de seguradores privados nesse nicho econômico.

A atividade de seguro de crédito já conta com significativa participação no comércio global. De acordo com Andreas Klasen (2014, p. 26), as ECAs, junto com as seguradoras privadas, responderam por $11 \%$ do comércio global em 2013. O autor salienta que a atividade das ECAs é especialmente importante nos mercados emergentes, onde elas preenchem o espaço deixado por seguradoras privadas e pelos bancos.

Além da atuação em situações nas quais se identificam "falhas de mercado", Chauffour, Saborowski e Soylemezoglu salientam outras duas justificativas para o 
estabelecimento de ECAs: (i) elas têm importante papel ao ajustar termos de crédito para externalidades não financeiras (efeitos de "spillover" ${ }^{\text {,50 }}$ da economia doméstica, custos de segurança nacional, externalidades ambientais) surgidas das falhas dos mercados domésticos não financeiros; (ii) elas compensam o apoio injusto de outros governos a seus exportadores (2010, p. 10). A importância de atuar em situações de falhas de mercado é assim resumida por Anders Grath (2012, p. 125):

O objetivo primeiro de uma Agência de Crédito de Exportação é complementar o mercado de seguros privado ao assumir riscos de crédito que este setor é incapaz de ou relutante a aceitar, a termos competitivos. ${ }^{51}$

Ademais, ainda que não se demande uma análise mais detida para os fins desta dissertação, é importante destacar a existência de estudos econométricos analisando os mercados austríaco (BADINGER; URL, 2012) e alemão (KLASEN, 2014), ambos a indicar que a atuação das ECAs afeta positivamente o volume exportado pelos países, em especial ao desempenhar o papel de redutor de volatilidades do financiamento ao comércio internacional.

Atualmente, percebe-se uma tendência de aperfeiçoamento dos modelos de seguros como fomento à internacionalização dos países (via exportações ou investimentos no exterior), principalmente após a adoção das "Commercial Interest Reference Rates" (CIRR) pelos países membros do chamado Arrangement on Officially Supported Export Credits da OCDE. Conforme expõe Santos (2011, p. 187), as CIRR introduziram um piso para as taxas de juros cobradas no financiamento às exportações, de modo a disciplinar a atuação daquelas agências e evitar práticas abusivas de competição comercial. O mesmo autor identifica, portanto, um redirecionamento das políticas públicas dos países desenvolvidos, que passam a concentrar esforço no campo do seguro de crédito e garantias, em razão da limitação em termos de financiamento.

\footnotetext{
50 Os efeitos de "Spillover" podem ser livremente traduzidos como efeitos de respingamento ou transbordamento. O termo é aplicado na teoria econômica de modo geral, indicando a existência de benefícios não diretos derivados de uma determinada ação econômica. A respeito dos efeitos "spillover" em favor de micro, pequenas e médias empresas em matérias de investimento externo direto, ver Khee Giap Tan e Kong Yam Tan (2015, pp. 3-7)

${ }^{51}$ No original "The primary objective of an ECA is to supplement the private insurance market by assuming credit risks which this sector is unable or unwilling to accept at competitive terms".
} 


\subsubsection{Embasamento jurídico dos seguros via ECAS}

Os seguros providos por ECAs, sejam eles voltados à proteção de crédito ou à proteção de investimentos, constituem contratos firmados entre, de um lado, o Estado, e de outro, um exportador, um investidor ou uma instituição financeira. Por conterem elementos de direito público e de direito privado, a natureza desses contratos é híbrida, e o embasamento da atuação do Estado com essa atividade engloba justificativas de caráter interno e internacional. Afinal de contas, um contrato de seguro de investimento no exterior é parte de um regime nacional voltado para atividades internacionais.

\subsubsection{A nova proteção diplomática?}

Como foi mencionado na introdução, as primeiras soluções jurídicas desenvolvidas pelo direito internacional para prevenir prejuízos ao investimento no estrangeiro e, quando não possível, restaurar danos, envolveram a noção de proteção diplomática.

José Carlos de Magalhaes lembra que as primeiras controvérsias relativas aos efeitos jurídicos decorrentes de vicissitudes que afetassem investimentos estrangeiros eram resolvidas por atuação unilateral dos Estados (2012, p. 114). A resolução unilateral dos Estados indica, nesse contexto, a prevalência do Estado mais forte ${ }^{52}$, mas isso não impediu o desenvolvimento de respostas jurídicas que viessem a proteger o Estado hospedeiro do investimento da intervenção armada por parte de países mais poderosos militarmente.

A solução de maior reconhecimento, ainda que não sujeita a aclamação geral, foi o dispositivo chamado de "cláusula Calvo", cujo nome homenageia o jurista argentino Carlos Calvo ${ }^{53}$. A referida cláusula impunha ao investidor estrangeiro a

\footnotetext{
${ }^{52}$ Esse tipo de ação estatal ficou conhecido como "diplomacia das canhoneiras" ou "gunboat diplomacy". Raymond Aron (2002, p. 116) relata a capacidade persuasória dessa medida: "ao envio de um vaso de guerra ao porto de um país que não pagava suas dívidas, desprezava os compromissos assumidos ou nacionalizada uma concessão feita a companhia estrangeira, para simbolizar a capacidade e a decisão de coagir, se necessário com o emprego das armas. Bastava o símbolo: a passagem à ação nunca chegava a ser necessária. Chamando à ordem, o país mais fraco cedia".

${ }^{53}$ A Cláusula Calvo não foi, na realidade, uma cláusula proposta por Carlos Calvo. Segundo sustenta Tumbarini (2002), a cláusula derivou de princípios de direito internacional apresentados pelo jurista em sua obra Derecho Internacional teórico y práctico, de 1868, quais sejam: (i) os Estados soberanos gozam do direito de liberdade contra qualquer sorte de interferência por parte de outros Estados; (ii) os estrangeiros têm os mesmos direitos que os nacionais, e em caso de pleitos ou reclamações, terão a obrigação de esgotar os recursos internos perante os tribunais locais, sem pedir proteção ou intervenção
} 
renúncia à proteção diplomática por seu país de origem, em caso de disputas envolvendo o Estado hospedeiro e o investidor, relativamente ao investimento realizado. A renúncia baseava-se no princípio do tratamento igualitário que deveria ser conferido a investidores nacionais e estrangeiros em uma dada jurisdição. A responsabilidade internacional do Estado hospedeiro, a justificar a proteção diplomática, somente encontraria guarida em caso de denegação de justiça, e os países latinoamericanos compreendiam esse conceito como a "inexistência de tribunais regulares no país ou negligência na administração da justiça" (MAGALHÃES, 2012, p. 118). Pesava contra a cláusula calvo o argumento de que os investidores não tinham o direito à renúncia de proteção diplomática de seus Estados, na medida em que essa prerrogativa seria própria destes, e não de seus nacionais.

Para Magalhães, a cláusula calvo teve o importante efeito de repelir, em certo sentido, a aplicação, na América Latina, de regimes pouco equilibrados constantes em tratados assinados entre países europeus e nações do Oriente, pois esses textos conferiam tratamento e jurisdição especiais aos estrangeiros (2012, p. 118). A discussão a respeito da controvérsia entre tratamento nacional e proteção diplomática, no entanto, perdeu efeito ao longo do século XX, em razão do declínio da "intervenção direta e coercitiva dos países mais fortes, em defesa dos interesses de seus nacionais no exterior, como ocorria no século XIX” (2012, p. 119).

Em que pese a diminuição da frequência da intervenção direta como forma de proteção diplomática, note-se que o século XX assistiu a uma transformação do modelo de proteção, pelo Estado, de interesses financeiros de seus nacionais no exterior. No tocante aos investimentos, o movimento mais notável foi justamente o de criação de regimes de seguro de investimentos por agências governamentais. Ou seja, a proteção diplomática passou a ser contratualizada.

\footnotetext{
diplomática de seu país de origem. A articulação desses princípios levou outros juristas e autoridades a negar a interferência de Estados estrangeiros para cobrar créditos em favor de nacionais seus, decorrentes de danos sofridos em durante guerra civil, atos de subelevação ou fatos congêneres. Na forma de cláusula, a negativa de investidores estrangeiros de pedir proteção diplomática de seus países de origem, contrapondo-se à doutrina de direito internacional prevalecente no século XIX, no sentido de que um ato contra um cidadão de um país era um ato contra o próprio país, a justificar a intervenção estatal. Tamburini cita que o primeiro caso com referência às ideias de Calvo ocorreu no México em 1873. Segundo afirma, o então ministro de relações exteriores mexicano Lafragua "dirigió una nota al embajador norteamericano Foster sosteniendo que México no era responsable de los daños causados a las propiedades extranjeras como opinaba el jurista argentino Calvo. Foster contestó que Calvo no era un autor aceptado internacionalmente. Será la primera manifestación de disentimiento por parte de los Estados Unidos que a partir de aquí, se demostrarán unos feroces adversarios de la doctrina Calvo. Por otro lado los internacionalistas sudamericanos lucharon sin descanso para que las ideas de Calvo fuesen aceptadas universalmente y fuesen parte del derecho internacional".
} 
À época da proteção diplomática, o investidor nacional instava o seu Estado de origem a assumir como sua a pretensão pelos danos sofridos no Estado hospedeiro. A participação do Estado na defesa dessa pretensão, contudo, dependia justamente do tamanho da empresa investidora afetada e de sua capacidade de mobilizar o governo de seu Estado a protegê-lo. Ao assumir essa prerrogativa, o Estado não exercia uma atividade econômico-financeira, mas, sim, para tentar reaver prejuízos de seus nacionais. O contrapeso dessa balança seria, no mais das vezes, o custo políticodiplomático da empreitada.

O seguro de investimentos, por sua vez, transmuda a prerrogativa do Estado, atuando por meio da longa manus das ECAs, em um negócio, na medida em que as entidades que prestam esse serviço o fazem seguindo preceitos atuariais que buscam, no longo prazo, reforçar a sustentabilidade econômica do regime. A proteção estatal não é concedida, mas contratada, envolvendo a cobrança de prêmio e eventual apresentação de contragarantias. Além disso, ainda que os Estados indenizem seus nacionais pelos danos sofridos, as cláusulas contratuais podem permitir que o investidor ceda, à Garantidora/Seguradora, seus ativos no estrangeiro. Ao subrogar-se em direitos que antes eram do investidor, as ECAs podem buscar o direito de regresso contra o Estado hospedeiro dos investimentos, o que, em caso de sucesso, propriciará a redução dos custos gerados pelo pagamento da indenização. Assim, por exemplo, se uma refinaria coberta pelo seguro é nacionalizada pelo Estado hospedeiro, sem indenização, o contrato de seguro permitirá que a empresa prejudicada seja imediatamente indenizada no valor dos seus ativos perdidos, e as pretensões sobre esses ativos passarão à agência garantidora, que buscará monetizá-los a fim de pleitear uma devolução pelo Estado estrangeiro, o que diminuirá as perdas da seguradora.

A lógica contratual pode assumir várias facetas, a depender do risco coberto. Um outro caso corrente é o de não convertibilidade de divisas, problema atualmente comum em países com restrição de dólares em razão de constrangimentos de comércio. A título de ilustração, a queda do preço do petróleo atinge severamente a reserva de divisas de alguns países dependentes deste produto em sua pauta exportadora, como Venezuela e Angola. Essa dificuldade de converter divisas pode, no limite, impedir que a empresa segurada retire seus lucros e dividendos do país hospedeiro dos investimentos. Caso isso ocorra em Angola, por exemplo, caberá a agência seguradora indenizar, em moeda forte, o investidor que se encontra com valores em moeda local não convertidos (no caso de Angola, o Kwanza). A Overseas Private Investment 
Corporation (OPIC), agência americana responsável por seguros de investimento para empresas americanas, costuma aproveitar moedas locais "presas" em favor de estruturas burocráticas já instaladas naquele mesmo país. Assim, despesas locais realizadas pela embaixada americana podem ser liquidadas com montantes em Kwanza cuja conversão não foi realizada por investidor segurado (GORDON, 2008, p. 105). Esse é um caso de atuação pró-negócios - e muito inteligente - na utilização, pelo Estado, do mecanismo do seguro de investimentos.

Com efeito, comparando-se a proteção diplomática tradicional com o seguro de investimentos, percebe-se que o seu objetivo primordial das proteções oferecidas é semelhante: trazer para o Estado do investidor as pretensões deste a respeito dos prejuízos financeiros causados por razões não comerciais no Estado hospedeiro. Basicamente, nos dois casos, a relação deixa de ser investidor-Estado e passa a ser Estado-Estado. São muitos, contudo, os benefícios da contratualização para essa substituição de partes: (i) para o investidor, os valores são ressarcidos ex ante, ou seja, não há necessidade de que o seu Estado de origem ganhe uma disputa arbitral com o Estado hospedeiro para que haja indenização; (ii) para o Estado garantidor, os custos políticos da "substituição de peças" são significativamente menores, pois se trata de uma substituição prevista contratualmente. A mesma OPIC, por sinal, utiliza o mecanismo conhecido como prior notification, consistente no envio prévio de notificação ao Estado hospedeiro, informando-o que um dado projeto americano está garantido pela agência (GORDON, 2012, p. 102). É uma forma eficaz de, já diplomaticamente, apresentar credenciais prévias caso haja algum problema; (iii) ainda para o Estado garantidor, a cobrança de prêmios dos segurados, a boa gestão do mecanismo de recuperação de indenizações e a correta calibragem atuarial do portfólio permitirão um regime autossustentável, sem necessidade de aportes constantes do orçamento estatal. Conforme se verá a seguir, os dados mais atuais a respeito da gestão desse tipo de seguro sugerem uma forma inteligente de intervenção do Estado na economia, a envolver, a um só tempo, a promoção de internacionalização de sua economia, a diminuição de custos políticos com outros Estados e a obtenção de superávits financeiros na prestação dessa atividade. 
2.2 Atualidades do seguro de investimento

Segundo o World Investment Report 2016 da UNCTAD (2016), existem, atualmente, mais de cem agências de apoio ao investimento no exterior. Os países desenvolvidos concentram 57\% dessas agências. Quando categorizados os tipos de apoio, contudo, nota-se que 27 das 34 instituições catalogadas que oferecem seguros ou garantias ao investimento - isto é, quase $80 \%$ - se encontram nos países desenvolvidos. Das sete agências restantes, seis estão situadas em países em desenvolvimento, enquanto apenas uma, a saber, a MIGA/Banco Mundial, é multilateral. Entidade já mencionada neste trabalho, a Overseas Private Investment Corporation (OPIC) é uma agência independente criada em 1971, que oferece seguro de investimento contra riscos políticos para mais de 150 países, incluindo países atualmente considerados de alto risco $^{54}$ como República Democrática do Congo, Iraque, Afeganistão e Paquistão ${ }^{55}$. Como esse tipo de apoio visa somente a pessoas jurídicas norte-americanas (US persons), o país confere vantagens competitivas a suas empresas, que podem avaliar com outra perspectiva oportunidades em mercados emergentes.

Figura 6: Agências de apoio ao investimento no exterior, divididas por categoria, grupo de país e instituição regional ou multilateral.

Development Finance Institutions

101 OIAs

- Investment Guarantee Schemes

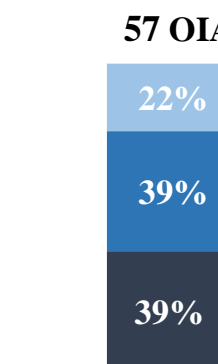

57 OIAs

$29 \%$

$39 \%$

28 OIAs

Developed

Economies

$39 \%$
$22 \%$
$39 \%$

16 OIAs

$94 \%$

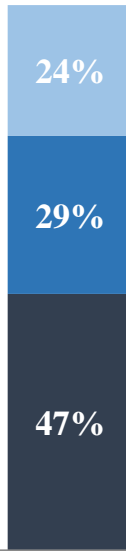

Fonte: UNCTAD World Investment Report 2016

\footnotetext{
${ }^{54}$ Para efeitos deste trabalho, são compreendidos como "país de alto risco" aqueles cuja classificação de risco pela OCDE seja 6/7 ou 7/7. Para acessar o Country Risk Classification: http://www.oecd.org/tad/xcred/cre-crc-current-english.pdf.

${ }^{55}$ Para saber mais: https://www.opic.gov/what-we-offer/political-risk-insurance.
} 
Segundo a Berne Union, organização internacional que congrega 82 companhias oriundas de 73 países, voltadas para o seguro de crédito à exportação e para o seguro de investimento, as operações desta última modalidade têm crescido paulatinamente. O registro histórico de operações, para o período 2011-2015, indica que aproximadamente US\$ 100 bilhões de novos investimentos estrangeiros diretos foram segurados por ECAs e seguradoras privadas vinculadas à associação.

Figura 7: Novos Investimentos Segurados - 2011-2015

(Em Milhões de Dólares)

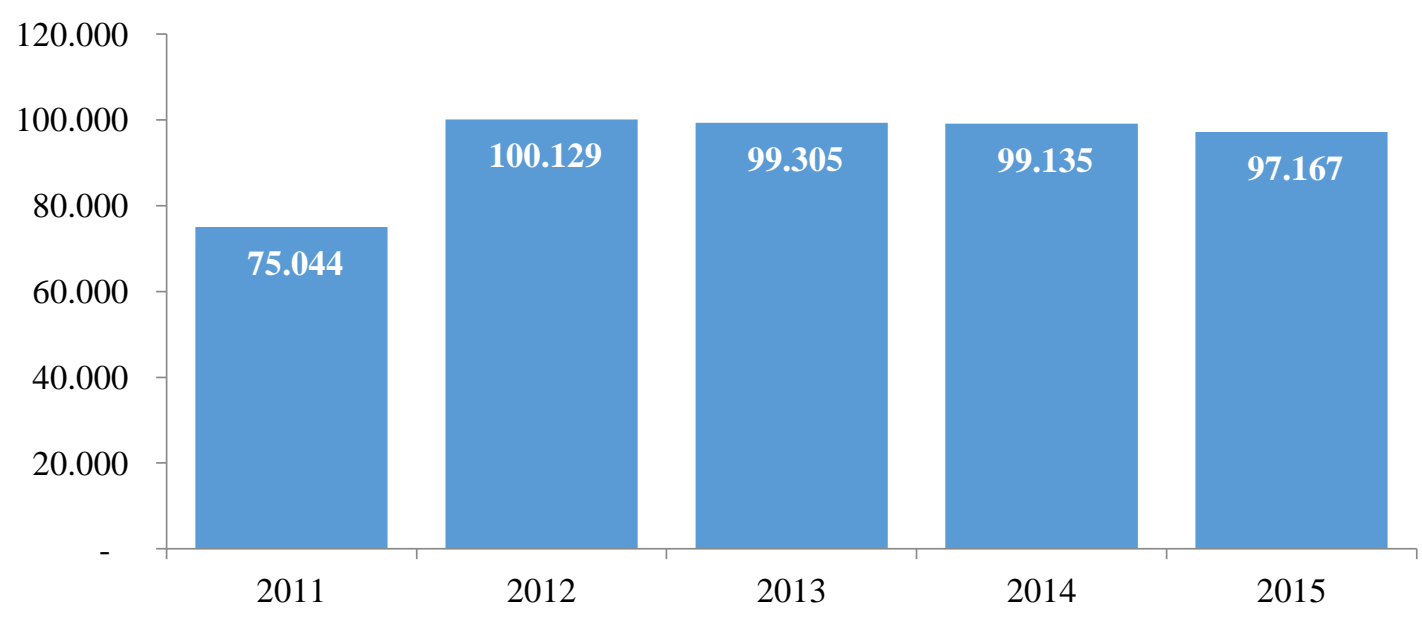

Fonte: http://www.berneunion.org/statistics/

O aparentemente baixo percentual de investimentos segurados é relativizado pelo fato de que essas operações garantidas estão concentradas justamente em países em desenvolvimento ,devido aos riscos políticos existentes. Esses países foram recipiendários de quase US\$ 800 bilhões em investimentos em 2015. O quadro abaixo indica que os países em desenvolvimento têm maior peso relativo como destinatários dos fluxos de investimento segurados. Importante notar que, apesar de o senso geral indicar que o Brasil não é um país hostil aos investimentos estrangeiros, os números indicam um relevante apetite dos investidores estrangeiros pela proteção de investimentos realizados no Brasil, o que indica uma percepção cautelosa em relação aos atos brasileiros de natureza política. 
Figura 8: Países recipiendários de investimentos segurados - Top 10 - 2015 (em US\$ milhões)

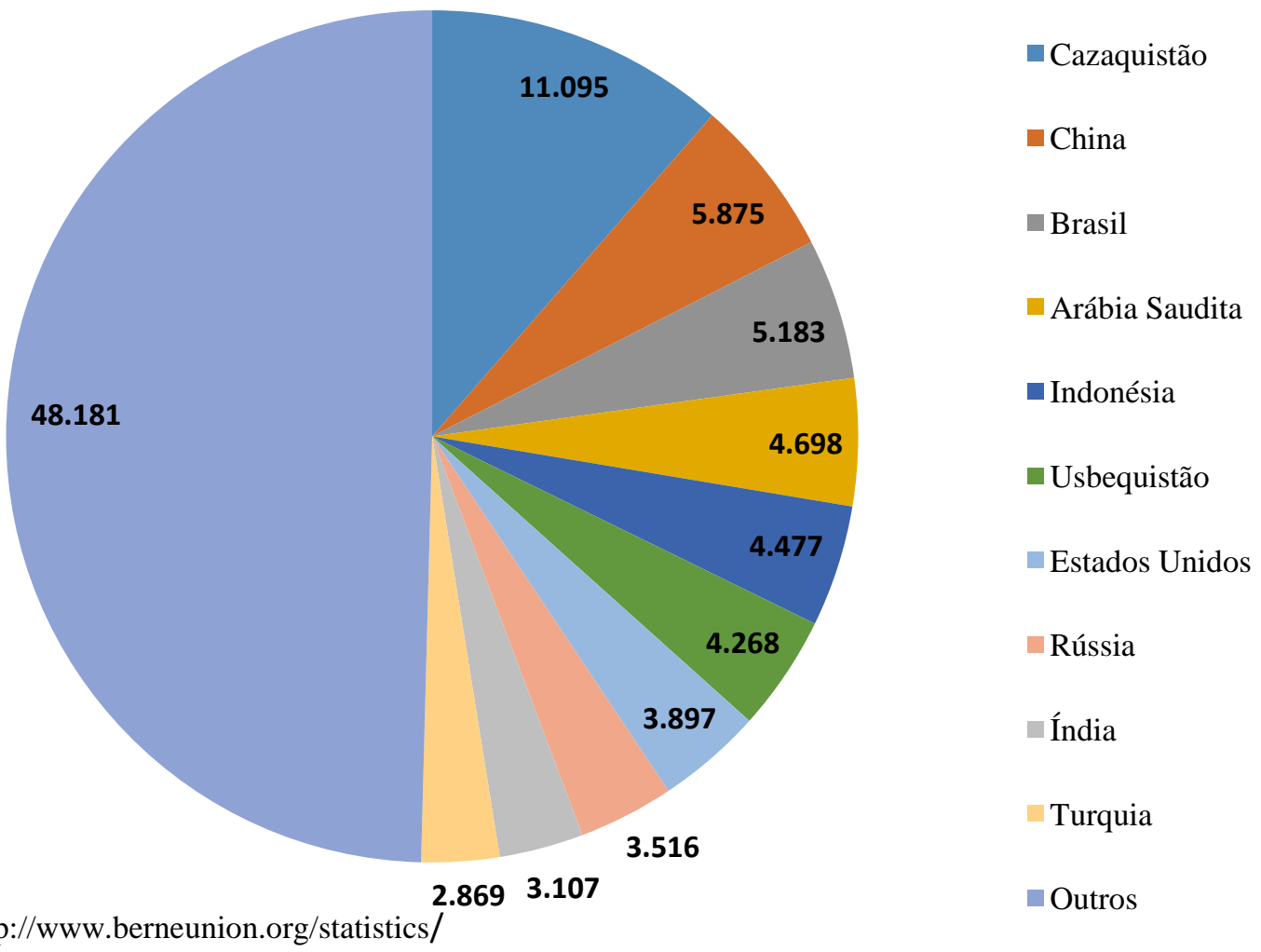

Uma dimensão mais precisa é fornecida pela comparação entre os números apresentados no gráfico acima e o histórico de investimentos recebidos pelos países indicados na Tabela $\mathrm{n}^{\mathrm{o}} 4$ abaixo:

\begin{tabular}{ccccccc}
\hline \multicolumn{2}{l}{ Tabela 4: Comparativo percentual investimentos segurados 2014-2015 (em US\$ milhões) } \\
\hline $\mathbf{A}$ & $\mathbf{B}$ & $\mathbf{C}$ & $\mathbf{D}$ & $\mathbf{E}$ & $\mathbf{D / B}$ & E/C \\
\hline País & $\begin{array}{c}\text { Investimentos } \\
\text { recebidos em } \\
\mathbf{2 0 1 4}\end{array}$ & $\begin{array}{c}\text { Investimentos } \\
\text { recebidos em } \\
\mathbf{2 0 1 5}\end{array}$ & $\begin{array}{c}\text { Investimentos } \\
\text { segurados em } \\
\mathbf{2 0 1 4}\end{array}$ & $\begin{array}{c}\text { Investimentos } \\
\text { segurados em } \\
\mathbf{2 0 1 5}\end{array}$ & $\begin{array}{c}\text { Percentual } \\
\text { investimentos } \\
\text { segurados } \\
\mathbf{2 0 1 4}\end{array}$ & $\begin{array}{c}\text { Percentual } \\
\text { investimentos } \\
\text { segurados } \\
\mathbf{2 0 1 5}\end{array}$ \\
\hline Cazaquistão & 8,406 & 4,021 & 10,386 & 11,095 & $123,55 \%$ & $275,93 \%$ \\
\hline China & 128,5 & 135,61 & 6,74 & 5,875 & $5,25 \%$ & $4,33 \%$ \\
\hline Brasil & 73,086 & 64,648 & 5,84 & 5,183 & $7,99 \%$ & $8,02 \%$ \\
\hline $\begin{array}{c}\text { Arábia } \\
\text { Saudita }\end{array}$ & 8,012 & 8,141 & 1,155 & 4,698 & $14,42 \%$ & $57,71 \%$ \\
\hline Indonésia & 21,866 & 15,508 & 4,82 & 4,477 & $22,04 \%$ & $28,87 \%$ \\
\hline Uzbequistão & 626 & 1,068 & 4,245 & 4,268 & $678,11 \%$ & $399,63 \%$ \\
\hline $\begin{array}{c}\text { Estados } \\
\text { Unidos }\end{array}$ & 106,614 & 379,894 & 5,288 & 3,897 & $4,96 \%$ & $1,03 \%$ \\
\hline Rússia & 29,152 & 9,825 & 4,1 & 3,516 & $14,06 \%$ & $35,79 \%$ \\
\hline Índia & 34,582 & 44,208 & 2,486 & 3,107 & $7,19 \%$ & $7,03 \%$ \\
\hline Turquia & 12,134 & 16,508 & 2,308 & 2,869 & $19,02 \%$ & $17,38 \%$ \\
\hline Fonte: Berne Union Statistics, Unctad Word Investment Report 2016. Elaboração do autor & & &
\end{tabular}


Os casos em que o percentual de investimentos segurados em um ano ultrapassa $100 \%$ sugerem a contratação de seguros para investimentos já existentes, ou seja, não relacionados a um fluxo financeiro ocorrido no mesmo ano, ou mesmo o caso de reinvestimentos de lucros. Os dados, portanto, não são suficientes para que se caracterize qual país tem o maior percentual de investimentos segurados, embora possa indicar algumas nações com alto risco político, considerando o fluxo de investimentos e o fluxo de investimentos segurados. Não se pode deixar de notar também que, da lista dos países com o maior montante de investimentos segurados, apenas os Estados Unidos podem ser considerados, claramente, um país desenvolvido ${ }^{56}$. Ademais, a relação investimento recebido/investimento segurado é bem mais baixa que a relação encontrada para os outros países presentes na lista. Isso reforça a ideia de que são os países em desenvolvimento o foco principal dessa política.

O Brasil ainda não oferece aos investidores nacionais no exterior o seguro de investimento. A necessidade de mudar esse panorama vem sendo consistentemente levantada nos últimos tempos, de modo a demandar do Estado uma postura mais proativa e coincidente com o apetite dos empresários nacionais de aumentar o grau de internacionalização de nossa economia, que é muito baixo. A título de exemplo, o percentual de empresas exportadoras ainda é pequeno quando comparado com a média mundial. Conforme relatado pelo Ministério da Indústria, Comércio Exterior e Serviços no Plano Nacional de Exportações 2015-2018 (p. 1), a participação brasileira no comércio mundial ainda não é proporcional ao tamanho de sua economia. O Brasil historicamente apresenta níveis baixos de internacionalização, característica especialmente grave em situações de dificuldades econômicas internas como a atualmente vivenciada. Nesse sentido, o documento citado sublinha (p. 1):

O Brasil é a sétima maior economia do mundo, mas sua participação no comércio internacional ainda não traduz essa posição. A representatividade do comércio exterior de bens e serviços na economia brasileira - 27,6\% do PIB em 2013 - também é relativamente moderada. Nas seis maiores economias do mundo, a média desse indicador alcança 53,4\% do PIB. Países emergentes do grupo do BRICS também apresentam maior espaço do comércio exterior em suas economias: África do Sul $(64,2 \%)$, Índia $(53,3 \%)$, Rússia $(50,9 \%)$ e China $(50,2 \%) 1$. Conclui-se, portanto, que o comércio exterior brasileiro possui considerável potencial para crescimento, com benefícios imediatos e relevantes para a economia"

\footnotetext{
${ }^{56}$ Apesar de não dispormos de dados sobre esse ponto, é razoável pensar que parte significativa dos investimentos segurados nos EUA visem a cobrir riscos comerciais, uma modalidade de seguro não tratada neste trabalho.
} 
Além disso, é preciso destacar que as empresas brasileiras, em razão de seu nível de competitividade, tendem a encontrar maior facilidade concorrencial em outros países em desenvolvimento (VIEITAS; ABOIM, 2013) até porque os níveis regulatórios costumam ser menores, situação que permite uma adaptação de custos menos onerosa. Um outro fator relevante é a proximidade geográfica e a similaridade cultural: pesquisa $^{57}$ realizada pelo Instituto Dom Cabral com as principais empresas transnacionais brasileiras demonstra que, na maioria dos casos, as primeiras iniciativas de internacionalização das empresas entrevistadas direcionam-se aos mercados da América do Sul, conforme se verá na tabela abaixo:

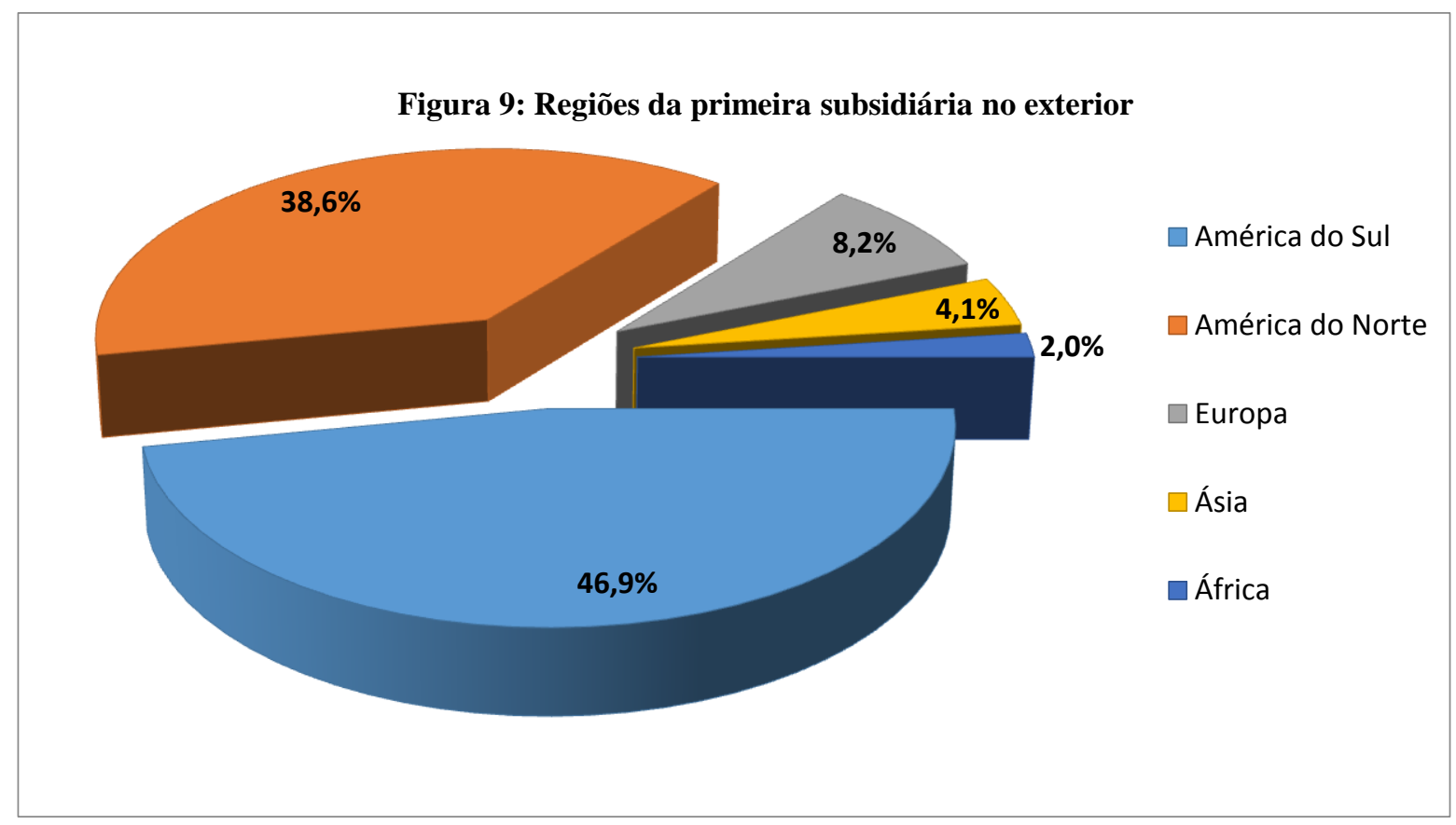

Fonte: Ranking FDC das multinacionais brasileiras 2016

Por sua vez, o gráfico a seguir indica quais países receberam as primeiras subsidiárias e franquias das empresas entrevistadas, e o número de empresas que iniciaram a operação internacional em cada um desses países:

\footnotetext{
${ }^{57}$ Participaram da pesquisa 64 empresas, das quais 50 multinacionais brasileiras que atuam no exterior, notadamente por com unidades próprias, e outras 14 empresas brasileiras que atuam no exterior por meio de franquias, principalmente.
} 
Figura 10: Países da primeira subsidiária no exterior

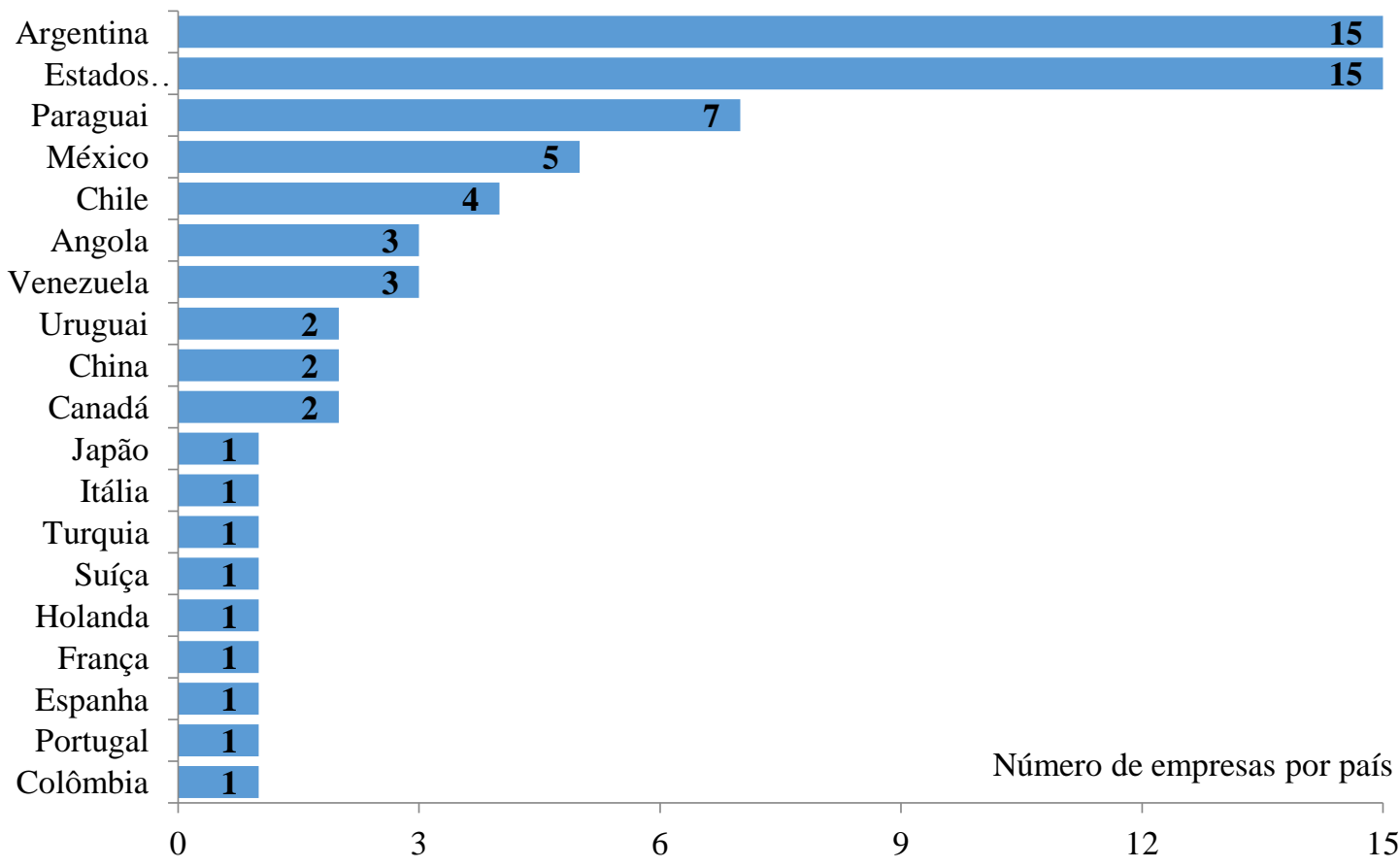

Fonte: Ranking FDC das multinacionais brasileiras 2016

O panorama acima apresentado reforça a ideia de que há uma tendência de expansão das empresas brasileiras para outros países em desenvolvimento, muitos deles nossos vizinhos na América do $\mathrm{Sul}^{58}$. Nesse sentido, pensar na cobertura de riscos políticos e extraordinários para investimentos brasileiros realizados nesses países converge com o apetite das empresas e não significa, necessariamente, uma revolução na política já praticada pelo governo brasileiro em relação a outros negócios. Afinal de contas, os riscos políticos e extraordinários já podem ser cobertos pelo governo brasileiro nas operações de Seguro de Crédito à Exportação para qualquer tipo de exportação (por exemplo, mercadorias), não importando o produto exportado, país importador, o tamanho da empresa ou o prazo da operação $\left(\operatorname{art.} 8^{\circ}, \S \S 2^{\circ}\right.$ e $8^{\circ}$ da Lei $n^{\circ}$ 6704/79). Já no caso de eventual criação de seguro de investimentos, em vez de a lei especificar quais riscos políticos e extraordinários impeditivos do recebimento do crédito pelo exportador/banco financiador serão cobertos, ela explicitaria em quais hipóteses os investimentos despendidos pela empresa estariam cobertos.

\footnotetext{
${ }^{58}$ Baumann e Gonçalves (2015, p. 207) indicam que a preferência de realizar investimentos em países da própria região é uma característica não só brasileira, mas situação comum em países em desenvolvimento que se internacionalizam.
} 
Mesmo que a criação de um seguro de investimentos implicasse o aumento do escopo do apoio oficial à internacionalização da economia brasileira, não se ultrapassaria a regra básica da atuação do governo nesse tipo de atividade: correção de falhas de mercado. Ademais, a experiência internacional também indica que os riscos dessa política pública podem ser administrados de maneira prudencial. A título de exemplo, cita-se o Relatório Financeiro da OPIC (2015, p. 5) - já mencionada neste trabalho $^{59}$ - relativamente ao ano de 2015 ressalta que, em apenas dois ${ }^{60}$ dos 44 anos fiscais da Agência, indenizou-se mais do que se arrecadou ${ }^{61}$. O mesmo relatório indica que um saldo operacional acumulado de mais de US\$ 5,5 bilhões desde o início das atividades da agência ${ }^{62}$. O programa de seguros da agência apresentou resultados expressivos nos dois últimos anos, com receita líquida operacional média de mais de US\$ 158 milhões ${ }^{63}$.

Tabela 5: Receita Operacional do Programa de Seguro de Investimento - OPIC/EUA

\section{Statement of Net Cost}

Overseas Private Investment Corporation - For the years ended September 30, 2015 and 2014

\begin{tabular}{lrr}
\hline (In Thousands) & 2015 & 2014 \\
\hline Insurance Program & & \\
\hline Gross Costs & 32.824 & 32.429 \\
\hline \multicolumn{1}{l}{ Operating Costs } & -60.492 & -26.059 \\
\hline Insurance Claim Recovery & -27.668 & 36.370 \\
\hline Total Gross Costs & -162.660 & -162.432 \\
\hline Less: Earned Revenue & -190.328 & -126.062 \\
\hline Net Insurance Program Costs & &
\end{tabular}

Fonte: OPIC Finnancial Report

2015

\footnotetext{
${ }^{59}$ A esse respeito, conferir Subseção 3.1.3.1

${ }^{60} \mathrm{O}$ mencionado Relatório não indica quais são esses anos.

${ }^{61}$ No original: "Risks - As a lender and insurer in developing countries, OPIC faces and manages the possibility that a significant credit or insurance event affecting multiple transactions could trigger net losses in OPIC's portfolio. While unlikely, it is possible that these events could result in costs exceeding collections in a future fiscal year. However, only two of the Corporation's 44 years resulted in the Corporation expending more cash than it collected".

${ }^{62}$ No original:" By charging fees and focusing on sustainable projects, OPIC operates at no net cost to the Treasury or tax-payer Since the agency's establishment in 1971, OPIC has generated cumulative results of operations of $\$ 55$ billion" OPIC, op. cit, p. 7.
}

${ }^{63}$ OPIC, op. Cit, p. 19. 
A Berne Union, ao consolidar resultados dessa política no mundo, infelizmente não divulga o montante dos prêmios arrecadados em operações de seguro de investimento, situação que impede a realização do cálculo de sinistralidade - ou loss ratio - consistente na divisão do montante de indenizações pagas pelo montante de prêmios arrecadados. Apesar disso, é possível mensurar o default histórico do período 2011-2015, correspondente ao percentual das indenizações pagas sobre a exposição total concretizada. As duas figuras abaixo demonstram uma taxa de default baixíssima, sempre menor que $0,1 \%$ no período analisado. Ou seja, a cada US\$ 1 bilhão em exposição (dados da figura 11 abaixo), paga-se menos de US\$ 1 mi em sede de indenizações (dados da figura 12 abaixo), valor consideravelmente abaixo da renda esperada com prêmios futuramente arrecadados.

Figura 11: Exposição em Seguro de Investimento 2011-2015

(Em Milhões de Dólares)

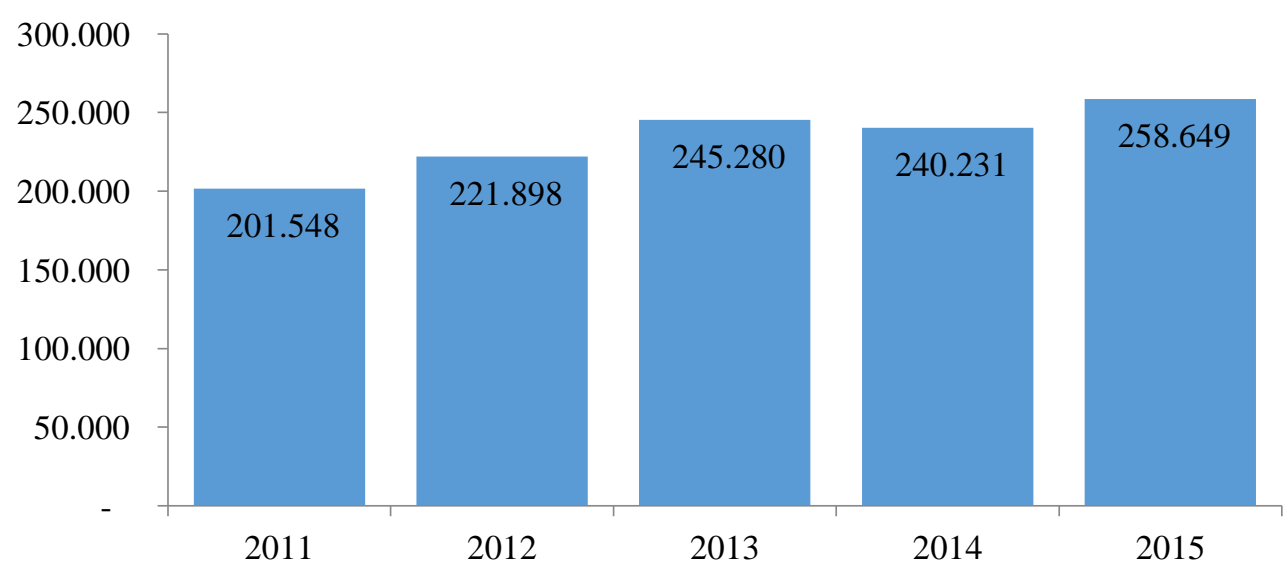

Fonte: Berne Union Statistics

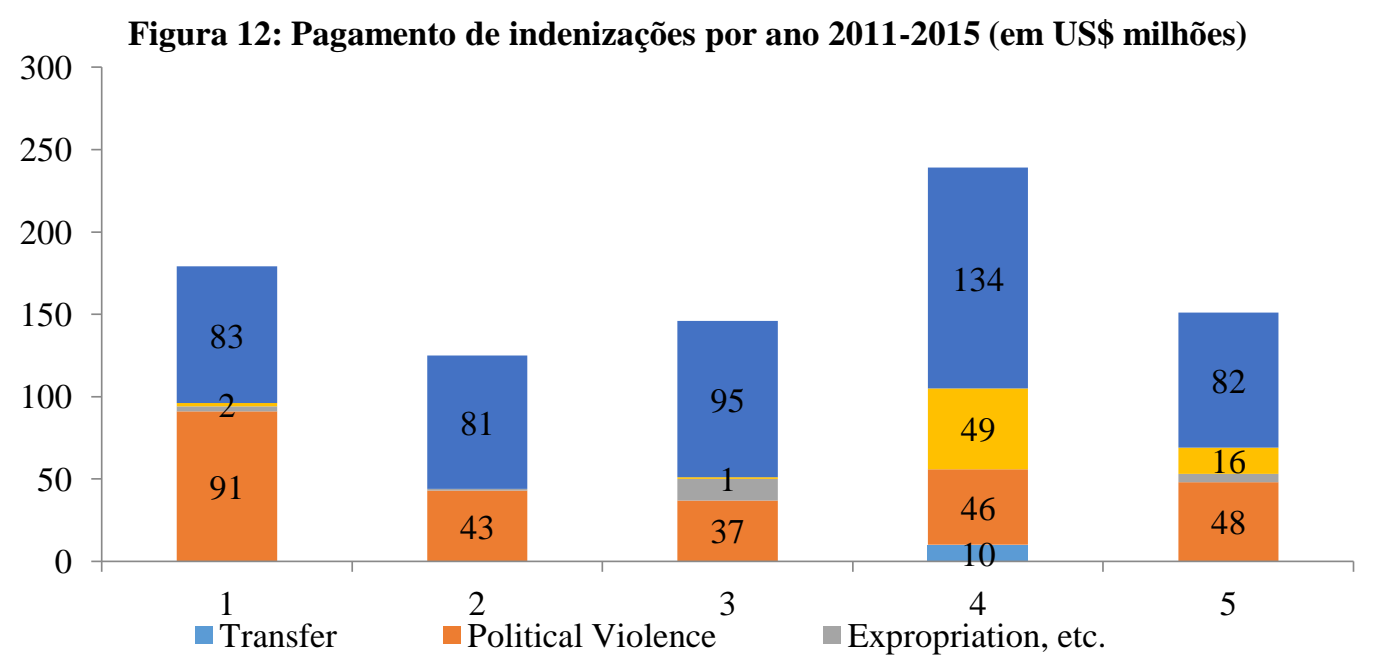

Fonte: Berne Union 


\section{A AJPE E OS REGIMES DE SEgURO DE INVESTIMENTOS}

No Brasil, a consagrada obra - de inquestionável contribuição acadêmica - “A Ordem Econômica na Constituição de 1988”, de Eros Roberto Grau, traz uma curiosidade interessante. Conquanto influencie, direta ou indiretamente, a quase totalidade da produção de textos acadêmicos no Brasil sobre direito econômico, a obra traz como referências bibliográficas apenas dois autores da área da economia: (i) Adam Smith, pai da economia moderna e consultado por sua seminal "Uma investigação sobre a natureza e a causa da riqueza das nações"; (ii) Luiz Gonzaga de Mello Belluzzo, economista brasileiro - apesar de ter-se graduado em Direito -, consultado por seu artigo "O desafio da perestroika", de 1989 e por prefácio escrito para o livro "Crise e Trabalho no Brasil", de 1996, coordenado por Carlos Alonso Barbosa de Oliveira e Jorge Matoso. Naturalmente, a escassa referência a textos econômicos influencia a orientação e a linguagem do singular trabalho do ex-ministro do STF. Essa evidência não indica falha na obra, pois há imenso valor acadêmico no recorte exclusivamente jurídico de qualquer tema de interesse do direito, inclusive o econômico, para fins didáticos ou simplesmente por escolha epistemológica ${ }^{64}$. Antes, essa constatação apenas alerta que a interdisciplinaridade corriqueiramente presumida ao se falar no direito econômico não necessariamente encontra respaldo na prática da produção bibliográfica. Mais importante que isso, demonstra que a análise da economia pelo direito não implica, por vias automáticas, a análise da justiça econômica.

Não é sem razão, nesse sentido, o comentário de Marcus Faro de Castro (2013, p. 99-103). Observando a história jurídica brasileira, o professor pontua que os juristas sempre se preocuparam em defender a validade e a coerência formal de certas ideias jurídicas, mas nunca exploraram explicitamente as conexões entre argumentos legais e seus contextos econômicos e políticos. A ausência de efetiva interdisciplinaridade é especialmente importante quando se tem em mente que instituições e vocabulários jurídicos muito frequentemente têm papel importante ao promover ou inibir transformações que afetam a maneira pela qual a economia, as demandas sociais e as instituições políticas se entrelaçam na formação de políticas públicas (Castro, 2013, p. 62). No campo dos investimentos internacionais, que muito frequentemente põem em

\footnotetext{
${ }^{64}$ Aliás, o próprio professor Eros Grau reconhece, já nas primeiras linhas do capítulo inicial da obra, que o direito deixou de prestar-se à harmonização de conflitos e à legitimação do poder, passando a funcionar com o instrumento de implementação de políticas públicas - para ele, também uma forma de reforçar a legitimação de poder (GRAU, 2015, p. 15).
} 
choque perspectivas culturais, jurídicas e econômicas radicalmente diferentes, as imbricações de fatores extralegais para a formação do que possa ser percebido como justo tornam-se ainda mais especiais.

Diante do que se expôs, busco apresentar uma diferença entre o que entendo como análise juridicizada de políticas econômicas, e a análise jurídica de políticas econômicas. Dentro daquela categoria (análise juridicizada) compreendo não somente as reflexões realizadas no âmbito dos tribunais, mas todo estudo de casos concretos que encontre exclusivo suporte nas leis e normas jurídicas vigentes, com insuficiente atenção para os contextos políticos e econômicos que influenciam e são influenciados pela norma analisada. A análise juridicizada tende a analisar o caso - identificando suas características específicas - a fim de classificá-lo na posição mais adequada possível dentro do ordenamento considerado em seu aspecto formal. Nesse tipo de análise, ainda que a ideia de justiça seja um norte, não é claramente possível inovar. O analista limitase a considerar a Constituição e/ou o direito internacional, as normas legais e infralegais, os princípios gerais e a interpretação possível desse conjunto - seja a dos doutrinadores, a dos antigos julgados ou a sua própria.

A análise jurídica, por sua vez, tem como norte o ideal de justiça, concebida como a fruição empírica de direitos humanos e fundamentais. A análise jurídica, portanto, atenta para as consequências práticas das normas. Assim, vários detalhes do ordenamento dão suporte à análise jurídica, mas não a limitam, de modo que o analista poderá sugerir inovações jurídicas que pavimentem com maior eficácia um caminho mais justo para a estruturação das relações sociais. Ao criticar a concepção canônica do "direito como ciência", prevalecente na academia brasileira, Marcus Faro chama atenção para a necessidade de que a atuação do jurista não seja somente a de "guardião da ordem presente". Para o citado professor (CASTRO, 2012, p. 18), é preciso dar importância a outra função do jurista, qual seja, a de "facilitador da mudança, uma função orientada para a inovação e para o futuro".

Apresentadas as primeiras ideias acima, é possível afirmar que instrumentos de promoção de internacionalização da economia, como o seguro de investimentos, fazem parte do que entendemos por política econômica, na medida em que representam atos governamentais favoráveis à consecução de objetivos macroeconômicos do governo, com a diminuição do déficit da balança de rendas, o aumento da projeção comercial do 
país, a sua inserção mais qualificada nas cadeias globais de valor ${ }^{65}$, notadamente, por meio da melhoria da competitividade do empresário nacional. Outros exemplos de elemento de políticas econômica com esse propósito são o seguro de crédito à exportação $^{66}$, o Proex-financiamento, o Proex-equalização ${ }^{67}$ e o Reintegra ${ }^{68}$. Todos eles, de uma maneira ou de outra, buscam encorajar o empresário nacional a lançar-se para além das fronteiras brasileiras por meio de incentivos securitários, financeiros ou tributários. Nesse sentido, são instrumentos que podem ser classificados como integrantes de uma política de caráter produtivista, muitas vezes chamada de política industrial $^{69}$. Além disso, por buscarem primordialmente a melhoria da competitividade do empresário brasileiro, todos os programas citados acima baseiam-se necessariamente em análises relacionais, isto é, na parametrização de incentivos em comparação com o que outros países oferecem. Do contrário, seria impossível medir se a competitividade é ou não atingida.

Em termos de projeção econômica internacional, a competitividade sempre poderá ser afetada por elementos de ordem soberana. De um lado, temos as "regras do jogo" tradicionalmente conhecidas, como os custos tributários (diretamente estipulados pelo governo), os custos bancários (influenciados pela taxa de juros básica da economia e pelo risco-país) e os custos trabalhistas (vinculados à ordem social estabelecida no

\footnotetext{
${ }^{65}$ A respeito da atuação das agências de crédito à exportação em face das novas tendências de comércio mundial (notadamente, as cadeias globais de valor), conferir a pesquisa de Daniel Koldyk, Lewis M. Quinn and Todd Evans (2015), realizada sob os auspícios da Export Development Canada (EDC).

${ }^{66}$ O Seguro de Crédito à Exportação (SCE) é espécie de seguro ofertado pela União, com base na lei no 6.704, e tem a finalidade de garantir as operações de crédito à exportação contra os riscos comerciais, políticos e extraordinários que possam afetar: (i) a produção de bens e a prestação de serviços destinados à exportação brasileira; (ii) as exportações brasileiras de bens e serviços; (iii) - as exportações estrangeiras de bens e serviços, desde que estejam associadas a exportações brasileiras de bens e serviços ou contenham componentes produzidos ou serviços prestados por empresas brasileiras, com o correspondente compartilhamento de risco com agências de crédito à exportação estrangeiras, seguradoras, resseguradoras, instituições financeiras e organismos internacionais

${ }^{67}$ A respeito do Proex Financiamento e do Proex equalização, ver subseção 2.2.1 acima.
}

${ }^{68} \mathrm{O}$ Regime Especial de Reintegração de Valores Tributários para Empresas Exportadoras (REINTEGRA) é regulamentado pelo Decreto $\mathrm{n}^{\circ}$ 8.543, de fevereiro de 2015. O regime tem o objetivo de devolver, parcial ou integralmente, o resíduo tributário remanescente na cadeia de produção de bens exportados.

${ }^{69}$ Schapiro (2010a, p. 428) conceitua a política industrial da seguinte forma: "Trata-se, assim, de uma política dirigida imediatamente ao fomento do setor produtivo e mediatamente ao fortalecimento da competitividade nacional, motivada pela percepção de que os agentes privados podem ser carentes de um impulso governamental para empreenderem determinadas atividades industriais, que se mostram, no entanto, estratégicas para uma dada economia". 
país). Não restam dúvidas de que esses fatores são matéria de interesse estatal e influenciam o ganho ou a perda de competitividade de determinada empresa com investimentos no estrangeiro. Por outro lado, há fatores relacionados especificamente à proteção de "direitos de produção" 70 , como o acesso a mercados por meio de tratados comerciais (também negociados pelo governo), o estabelecimento de pontos focais para facilitar a interlocução entre governo e investidores (por meio de tratados de investimento, também negociados Estado-Estado) ou mesmo pela implantação de regimes legais nacionais de proteção ao risco soberano, como é o caso do seguro de investimento. Além disso, outros aspectos da concorrência menos aparentes do ponto de vista governamental são objeto intenso de planejamento estatal: a título de ilustração, citam-se a política de inovação das empresas, significativamente impactada por estímulos fiscais e financeiros oferecidos pelo governo, e o acesso a matérias primas, também dependente de quais regras o governo estabelecerá envolvendo temas como o meio-ambiente e a exploração de minas, jazidas ou outros recursos soberanos. No limite, basta pensarmos em quantas guerras (ou seja, decisões governamentais de beligerância) foram travadas com o objetivo de obter acesso facilitado a ativos naturais de alto valor produtivo (carvão, petróleo).

Veja-se que a competitividade dos setores privados depende enormemente de pacotes governamentais. Consequentemente, os governos também concorrem entre si para desenhar e implementar as políticas que sustentem a competitividade global dos investimentos estrangeiros de empresas nacionais. Essa concorrência, conforme já citado alhures, encontra em alguns casos parâmetros normativos estabelecidos internacionalmente, a fim de que os auxílios estatais não atinjam níveis nos quais o empresário não terá risco algum e será subsidiado em todos os seus custos. São exemplos desses parâmetros internacionais as regras estabelecidas pela Organização

\footnotetext{
${ }^{70}$ Castro (2014, p. 44) identifica os "direitos de produção" (em contraste com o que designa como "direitos de cosumo") nos seguintes termos: "[A] produção econômica e a troca comercial giram em torno da fruição, pelos atores econômicos, de "direitos de produção", que se referem a direitos enquanto sustentáculos jurídicos de atividades relacionadas à produção econômica e à troca [comercial]. 'Direitos de consumo', por outro lado, são uma referência para as práticas que adquirem significado (cultural, moral, religioso, etc.) a partir de atividades mediante as quais os atores expendem - e não se engajam intencionalmente na produção ou troca comercial de - produtos e serviços. Portanto, os "direitos de produção" são sempre equivalentes a uma forma de 'propriedade comercial', enquanto os 'direitos de consumo " podem ter a forma de diversos tipos de propriedade não comercial (individual ou coletiva) e também do que são frequentemente chamados 'direitos sociais' ou 'direitos econômicos, sociais e culturais' (DESCs). Tanto os direitos de produção quanto os direitos de consumo são formas de direitos fundamentais e humanos, presentes nas constituições nacionais e em tratados internacionais."
} 
Mundial do Comércio (OMC) e o Arrangement on Officially Supported Export Credits da $\mathrm{OCDE}^{71}$.

O que se propõe como exercício neste trabalho é a comparação dos diferentes regimes normativos, que serão mapeados com o uso da metodologia da Análise Jurídica da Política Econômica (AJPE). Diferentes países utilizam diferentes regimes, e não parece haver um critério comum preciso para mensurar o grau de proteção ao investidor beneficiado por cada regime. Nesse sentido, é preciso atentar para um fato de enorme importância, porém pouco discutido: sem uma criteriosa comparação entre as medidas de proteção aos investimentos oferecidas pelos diversos países, não há como assegurar que um regime de seguro de investimentos eventualmente lançado pelo governo brasileiro seja eficaz e capaz de atingir os objetivos a que se propõe. Afinal de contas, em termos empíricos, concorrentes internacionais de empresas brasileiras podem usufruir de um maior grau da proteção ofertada pelos regimes nacionais de seguro de investimento de seus países, e isso redundaria em uma situação injusta, em detrimento da efetividade dos direitos de empresários brasileiros.

\subsection{Metodologia da AJPE}

Segundo Castro, "a AJPE considera a política econômica como conjunto de regras politicamente instituídas que organizam a produção, a troca e o consumo na vida social" (CASTRO, 2009, p. 22). Talvez a principal contribuição da AJPE no âmbito do estudo das relações entre direito e economia seja aquela mencionada por Albério Junio Rodrigues Lima, para quem a AJPE “inverte a lógica de se pensar o direito sob fundamentos econômicos, realizando uma análise de como as decisões de ordem econômica afetam a fruição de direitos fundamentais e direitos humanos" (2014, p. 80).

O procedimento analítico proposto por Castro para a análise posicional envolve o cumprimento de oito etapas, a saber: “a) identificação de política pública ou econômica (ou componente de política pública ou econômica sujeita a controvérsias. $b$ ) Especificação de direito fundamental correlato. c) Decomposição analítica do(s) direito (s). d) Quantificação [da fruição] dos direitos analiticamente decompostos. e) Elaboração de índice de fruição empírica (IFE). f) Escolha ou elaboração de 'padrão de validação jurídica (PVJ). g) Avaliação dos resultados em termos de verificação da

\footnotetext{
71 Versão completa e atualizada do Acordo por ser encontrada no seguinte sítio eletrônico: http://www.oecd.org/officialdocuments/displaydocument/?doclanguage $=$ en $\&$ cote $=\operatorname{tad} / \mathrm{pg}(2017) 1$. Acesso em 10/02/2017.
} 
efetividade ou falhas ou ausência de efetividade. h) Na hipótese de falha ou ausência de efetividade, elaboração de recomendações de reformas" (CASTRO, 2009, p. 41-45). Passaremos a explorar cada uma dessas etapas a seguir.

3.1.1 Identificação de política pública ou econômica (ou componente de política pública ou econômica) sujeita a controvérsias

A política econômica a ser estudada é o conjunto de regras adotadas pelo estado brasileiro para estruturar o seguro de investimento no exterior. A seguir será utilizada a expressão "política de seguro ao investimento no exterior" (PSIE). No Brasil, por ainda não existir regime ou conjunto de regras em vigor nessa área, a PSIE é ainda "de lege ferenda", ou seja, tem atualmente a feição de proposta de política pública. Em 2016, um Projeto de Lei de Conversão instituindo o seguro de investimento, cuja relatoria pertencia ao Senador Douglas Cintra (PTB-PE) chegou a ser aprovado no Congresso Nacional, mas a iniciativa foi vetada pela Presidência da República no mesmo ano.

Interessante notar que a construção jurídica do seguro de investimento recebeu duas iniciativas em âmbito legislativo: a primeira iniciativa contou com participação direta do governo federal (ou parte dele) e outra por parte do mencionado Senador da República (Douglas Cintra), não por acaso suplente do então Ministro de Desenvolvimento, Indústria e Comércio Exterior (MDIC), Armando Monteiro Neto. O apoio do Senador Douglas Cintra à causa dos investimentos brasileiros no exterior indica percepção e absorção das propostas realizadas pela Confederação Nacional da Indústria (CNI), organização que congrega os principais atores privados afetados pelas políticas públicas do MDIC. Assim, é possível dizer que as vozes da CNI encontraram ressonância legislativa em um Senador da base do governo à época (Senador Douglas Cintra), de modo articulado com o principal ministério responsável pelas políticas voltadas à indústria nacional como um todo.

A construção jurídica do modelo se daria por caminhos paralelos. A proposta governamental previa uma autorização legislativa do modelo de seguro por Lei Complementar, tendo em vista a sua vinculação a um fundo garantidor. Em razão da tramitação do Projeto de Lei Complementar n 257/2016, a tratar do pacto entre Estados e União e da consequente alteração da Lei Complementar $n^{\circ}$ 101/2000, conhecida como a Lei de Responsabilidade Fiscal, encontrou-se oportunidade para propor a alteração do art. $40, \S 8^{\circ}$, II, com a seguinte mudança: 
Tabela 6: Proposta de Mudança do PLC à Lei Complementar no 101/2000

\begin{tabular}{|c|c|}
\hline De: & Para: \\
\hline $\begin{array}{l}\text { Art. 40. Os entes poderão conceder garantia } \\
\text { em operações de crédito internas ou externas, } \\
\text { observados o disposto neste artigo, as normas } \\
\text { do art. } 32 \text { e, no caso da União, também os } \\
\text { limites e as condições estabelecidos pelo } \\
\text { Senado Federal. } \\
\S 8^{\circ} \text { Excetua-se do disposto neste artigo a } \\
\text { garantia prestada: } \\
\text { (..) } \\
\text { II - pela União, na forma de lei federal, a } \\
\text { empresas de natureza financeira por ela } \\
\text { controladas, direta e indiretamente, quanto às } \\
\text { operações de seguro de crédito à exportação. }\end{array}$ & $\begin{array}{l}\text { Art. 40. (...) } \\
\S 8 \text { o Excetua-se do disposto neste artigo a garantia } \\
\text { prestada: } \\
\text { (..) } \\
\text { II - pela União, na forma de lei federal, a empresas de } \\
\text { natureza financeira por ela controladas, direta e } \\
\text { indiretamente, bem como a entidades privadas } \\
\text { nacionais e estrangeiras, Estados estrangeiros, } \\
\text { agências oficiais de crédito à exportação e organismos } \\
\text { financeiros multilaterais quanto à operações de } \\
\text { garantia de crédito à exportação, de seguro de crédito } \\
\text { à exportação, e de seguro de investimento, hipóteses } \\
\text { nas quais a União está autorizada a efetuar o } \\
\text { pagamento de indenizações de acordo com o } \\
\text { cronograma de pagamento da operação coberta } \\
\text { (destaque nosso) }\end{array}$ \\
\hline
\end{tabular}

Perceba-se que a União aproveitava a oportunidade de agenda para incluir não somente o seguro de investimento, mas também outros temas de interesse da gestão do Fundo de Garantia à Exportação, tais como: (i) compartilhamento de risco; (ii) garantia de crédito à exportação; (iii) autorização explícita de pagamento parcelado de indenizações. Essas alterações, contudo, não serão objeto do presente trabalho.

O maior objetivo do Projeto de Lei Complementar seria instituir o seguro de investimento no "vocabulário" de garantias prestadas pela União, a fim de que não se alegasse sua ausência de previsão na chamada Lei de Responsabilidade Fiscal ${ }^{72}$. A forma de execução e seus limites, no entanto, seriam objeto de nova lei federal, a ser posteriormente elaborada e discutida.

Durante a tramitação da Medida Provisória n ${ }^{\circ}$ 701/2015, o relator da Comissão Mista, Senador Douglas Cintra (PTB/PE), apresentou emenda com proposta de alteração das Leis $n^{\circ} 6.704$, de 26 de outubro de 1979, $n^{\circ} 9.818$, de 23 de agosto de 1999 $\mathrm{n}^{\mathrm{o}}$ 11.281, de 20 de fevereiro de 2006. Em seu Parecer $n^{\circ}$ 10/2016-CN, o Senador sustentou o seguinte:

Já a criação do seguro de investimento, por meio das alterações nos arts. $1^{\circ}$ e $4^{\circ}$ da Lei $n^{\circ} 9.818$, de 1999 , e nos art.s $2^{\circ}$ e $4^{\circ}$ da Lei $n^{\circ}$ 11.281 , de 2006, e da inclusão dos arts. 10 a 16 no texto do PLV, tem por finalidade estimular a internacionalização de empresas brasileiras, por meio da concessão de garantias ao investimento brasileiro em empresas novas ou já constituídas em outros países. A cobertura será

\footnotetext{
${ }^{72}$ Lei Complementar $\mathrm{n}^{\circ}$ 101, de 4 de maio de 2000.
} 
limitada aos riscos políticos e extraordinários do país alvo dos investimentos, de modo que o risco comercial ordinário permanecerá com o empresário. Trata-se de passo fundamental para modernizar o arcabouço normativo brasileiro, ante o cenário de crescente globalização, adequando-o às melhores práticas internacionais ${ }^{73}$.

O parecer da Comissão Mista ${ }^{74}$ foi apresentado em 12/04/2016 e aprovado 03/05/2016 pelo Plenário da Câmara dos Depurados. A Medida Provisória no 701 de 2015 então seguiu ao Senado na forma do Projeto de Lei de Conversão ${ }^{75} \mathrm{n}^{\mathrm{o}} 7$ de 2016 , no qual constava, entre outras alterações, a inclusão do seguro do investimento no exterior. A parte do projeto relativa ao seguro de investimento, todavia, foi vetada pela Presidência da República em 31 de maio de $2016^{76}$, sob a justificativa de elevar "sobremaneira o risco potencial do FGE e, com isso, podendo gerar possíveis impactos fiscais relevantes à União".

Não há dúvidas, portanto, de que havia controvérsia em relação à proposta legal, tendo em vista que a iniciativa não deixou de contar com o apoio de parte do governo, mas terminou por ser vetada pela Presidência da República. Esse veto, no entanto, teve natureza menos meritória e mais acautelatória, pois a fundamentação apresentada dizia respeito ao "risco potencial" de tornar financeiramente insustentável o Fundo de Garantia à Exportação, já responsável por lastrear as operações de seguro de crédito à exportação, e indicado, no projeto de lei, para lastrear também as operações de seguro de investimento no exterior. Ao que parece, o próprio governo não gozava de informações suficientes a respeito do impacto da medida, de modo que se achou prudente vetá-la, o que não invalida o valor da iniciativa ${ }^{77}$. As características do Projeto

\footnotetext{
${ }^{73}$ Parecer no 10 de 2016 - CN. Disponível em http://www.camara.gov.br/proposicoesWeb/prop_pareceres _substitutivos_votos;jsessionid=C56CD81872C8CDFA3EB3F2D13442C8B4.proposicoesWeb1?idPropo sicao $=2058404$. Acesso em 15/08/2016.

${ }^{74}$ Conforme disposto no art. $62, \S 9^{\circ}$ da Constituição Federal, "Caberá à comissão mista de Deputados e Senadores examinar as medidas provisórias e sobre elas emitir parecer, antes de serem apreciadas, em sessão separada, pelo plenário de cada uma das Casas do Congresso Nacional”.

${ }^{75}$ Sempre que o conteúdo de uma Medida Provisória é alterado durante a tramitação congressual, o texto modificado passa a receber o nome de Projeto de Lei de Conversão. A esse respeito, conferir: http://www2.camara.leg.br/comunicacao/assessoria-de-imprensa/medida-provisoria. Acesso em 10.02.2017.

76 Proferido por meio da Mensagem de Veto $\mathrm{n}^{\mathbf{o}} 304$, de 31 de maio de 2016. Disponível em http://www.planalto.gov.br/ccivil_03/_ato2015-2018/2016/Msg/VEP-304.htm. Acesso em 01/02/2017.

77 Também é razoável considerar que o cenário político instável e pouco amistoso de 2015 e 2016 - com processo de impeachment contra a então presidente Dilma Vana Rousseff, a ascensão ao cargo do então
} 
de Lei vetado serão analisadas abaixo, no tópico “Índice de Fruição Empírica (IFE)" e servirão de parâmetro para a comparação de um possível regime brasileiro de seguro de investimento no exterior com outros regimes já existentes, adotados em outros países.

\subsubsection{Especificação de direito fundamental correlato}

Ao tratar da especificação do direito fundamental, Castro (2009, p. 50) levanta a necessidade de que a natureza de produção ou de consumo do direito seja identificada, na medida em que há diferentes dimensões de análise a serem consideradas, a depender de um outro tipo de direito. Castro (idem) ainda estipula que os "direitos de produção" correspondem às "formas de propriedade com função [primária] produtiva", que contrastam, portanto, com a propriedade civil, dotada de função primária de consumo. A ideia aqui sustentada é a de que o seguro de investimento (ou sua ausência) impacta a fruição de um direito de produção, a saber, a dimensão internacional da própria liberdade de iniciativa da atividade empresarial.

Com efeito, em um mundo globalizado, de contínua e aprofundada interseção entre agentes externos, a avaliação da livre concorrência, principalmente no plano internacional, deve compreender a avaliação da paridade de instrumentos jurídicos e financeiros oferecidos pelo Estado ao produtor nacional, em comparação com os mesmos instrumentos de que dispõem seus concorrentes internacionais. Como falar em livre concorrência quando, por exemplo, o financiamento tomado por um empresário nacional tem taxas de juros quatro, cinco vezes maiores que aquele tomado pelo seu concorrente no exterior, em se tratando de operações que sejam cursadas na mesma moeda, tenham o mesmo prazo e precifiquem risco semelhante? Do mesmo modo, como falar em promoção de internacionalização da economia, quando os investidores nacionais não desfrutam de direitos garantidos para investidores de outros países?

Confirmando a projeção internacional de uma política que busca garantir competitividade, Gordon (2008, p. 112) trata da missão declarada pelas agências governamentais que oferecem o seguro do investimento. Sobre isso, relata que 13 das 16 agências pesquisadas apresentam, como missão institucional, a "promoção de competitividade externa das entidades nacionais". As três agências a completar a lista Delcredere (Bélgica), COFACE (França) e OPIC (EUA) apenas não explicitam essa 
missão, situação que não significa que a promoção de competitividade não seja um aspecto de fato levado em conta na realização da política pública.

\subsubsection{Decomposição analítica do(s) direito(s)}

A decomposição analítica do direito sugere o levantamento de aspectos relevantes da política pública posta em discussão. No presente caso, o foco deve recair sobre aspectos de proteção que possam favorecer a fruição de direitos de produção em conexão com a implementação de um seguro de investimento no exterior. Assim, a decomposição exige a identificação de características relevantes da política focalizada, que podem influenciar a fruição do direito de produção (no presente caso, a propriedade comercial de empresários brasileiros), considerada a existência de um regime de seguro de investimento, tendo em vista ainda que tal regime pode ser mais, ou menos, protetor que outro, no sentido de garantir mais, ou menos, a efetividade do direito de iniciativa privada (ou propriedade comercial).

Tendo em vista os critérios acima, foram escolhidas três dimensões relativas a diferentes níveis de proteção do seguro de investimento. O primeiro nível de proteção refere-se à elegibilidade do investimento protegido, a depender da nacionalidade da empresa contratante. $\mathrm{O}$ segundo refere-se aos tipos de risco cobertos pelo seguro de investimento. O terceiro aborda elementos de conformidade com parâmetros socioambientais, trabalhistas e éticos, a fim de que o Estado se abstenha de promover atividades de seus nacionais que firam bens jurídicos cuja proteção é internacional ou é legitimamente valorizada como política local. Essas dimensões são listadas na divisão abaixo.

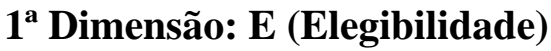

\begin{tabular}{|l|c|}
\hline Elegibilidade de empresas nacionais & $E_{1}$ \\
\hline Elegibilidade empresas estabelecidas em território nacional & $E_{2}$ \\
\hline Elegibilidade de subsidiárias estrangeiras de empresas nacionais & $E_{3}$ \\
\hline
\end{tabular}

\section{2 ${ }^{\mathrm{a}}$ Dimensão: $\mathrm{R}$ (Tipos de Riscos cobertos)}




\begin{tabular}{|l|c|}
\hline Risco de confisco ou expropriação direta & $\mathrm{R}_{2}$ \\
\hline Risco de confisco ou expropriação indireta & $\mathrm{R}_{3}$ \\
\hline $\begin{array}{l}\text { Risco de não cumprimento de obrigações do governo hospedeiro (empréstimos, } \\
\text { cláusulas contratuais etc) }\end{array}$ & $\mathrm{R}_{4}$ \\
\hline Risco de Guerra e outros eventos de violência política & $\mathrm{R}_{5}$ \\
\hline Risco de Terrorismo & $\mathrm{R}_{6}$ \\
\hline Risco de variação cambial decorrente de leis internas do país hospedeiro & $\mathrm{R}_{7}$ \\
\hline Riscos extraordinários ou force majeure & $\mathrm{R}_{8}$ \\
\hline
\end{tabular}

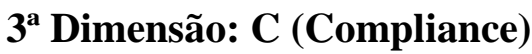

\begin{tabular}{|l|l|}
\hline Compliance social $^{78}$ & $\mathrm{C}_{1}$ \\
\hline Compliance ambiental & $\mathrm{C}_{2}$ \\
\hline Compliance anticorrupção & $\mathrm{C}_{3}$ \\
\hline Compliance trabalhista & $\mathrm{C}_{4}$ \\
\hline
\end{tabular}

3.1.4 Quantificação dos direitos analiticamente decompostos ${ }^{79}$

O presente trabalho não dispõe de dados que possam distinguir o peso atual de cada um desses aspectos. Assim, é impossível aferir quantas empresas nacionais gostariam de utilizar o seguro, em comparação a empresas estrangeiras estabelecidas em território nacional, por exemplo. Além disso, embora haja, por exemplo, dados sobre o montante de indenizações pagas por membros da Berne Union em virtude de cobertura de riscos de quebra de contrato $^{80}$, também não se mostra factível mensurar níveis de

\footnotetext{
${ }^{78}$ Segundo a pesquisa de Gordon (2008), o compliance social diz respeito à avaliação de impacto e de eventual deslocamento de comunidades locais afetadas pelo investimento.

79 A quantificação refere-se à fruição empírica do direito subjetivo considerado. O tratamento da quantificação e seu emprego na análise jurídica, nos termos da AJPE, seguem indicações fornecidas pela sociologia histórica da quantificação, em especial Alain Desrosières. Segundo este autor, toda quantificação realizada para fins práticos - por exemplo, em estatísticas - pressupõe a estipulação de convenções sociais. Este é o sentido da frase: 'quantificar é convencionar, depois medir' (Desrosières, 2008, 10). De um modo geral, no que se segue estão explicitadas as convenções subjacentes às mensurações originalmente realizadas neste trabalho. Além disso, naturalmente são indicadas as fontes (trabalhos) de mensurações feitas por outros autores e aproveitadas neste trabalho. Para uma discussão das relações entre a quantificação e seu emprego no direito, ver discussão em Castro (2016).
}

${ }^{80}$ Ver, a esse respeito, dados da Figura 12, na Seção 2.2 acima. 
proteção, já que os dados disponibilizados pela Berne Union são parciais e consolidados, de modo que não é possível determinar qual regime protegeu qual risco.

Em razão desse obstáculo de depuração, o exercício proposto é o de quantificar, de maneira binária - com valores 0 (zero) (em caso de inexistência ou ausência de informação sobre sua existência) ou 1 (um) (em caso de existência) - os atributos especificados nas variáveis, uma simplificação conhecida como modelo simples de uso variável dummy (MISSIO; JACOBI, 2007, p. 112). Sendo assim, a pontuação máxima que um regime pode receber é 3 para elegibilidade, 8 para níveis de proteção e 4 para conformidade. Esses valores serão somados, de modo que sua compreensão analítica pode ser descrita pelas seguintes notações matemáticas:

(i) $\quad(E)=E_{1}+E_{2}+E_{3}$

(ii) $\quad(R)=R_{1}+R_{2}+R_{3}+R_{4}+R_{5}+R_{6}+R_{7}+R_{8}$

(iii) (C) $=C_{1}+C_{2}+C_{3}+C_{4}$

3.1.5 A Elaboração de índice de fruição empírica (IFE) e a Elaboração de 'padrão de validação jurídica` (PVJ)

Dois passos da metodologia da AJPE são, aqui, tratados conjuntamente, em razão da intensa articulação mútua. O índice de fruição empírica (IFE) deve permitir a caracterização, em números, dos aspectos de fruição do direito pesquisado. No caso presente, tal caracterização serve também o propósito de comparar o regime proposto com outros já existentes, nos aspectos indicados na decomposição analítica. Assim, o exercício que se propõe é que a iniciativa legal vetada seja caracterizada sob o prisma das três primeiras dimensões somadas. O mesmo exercício será realizado para um conjunto de regimes estrangeiros existentes, e as respostas serão relacionadas em ranking próprio.

O padrão de validação jurídica (PVJ), por sua vez, será considerado uma projeção equivalente a um IFE "otimizado". Ou seja, caso todas as valorações gerem o resultado 1 , o resultado máximo de 15 pontos. Isso indicaria que um regime de seguro de investimento com esse resultado máximo seria aquele que protegeria a liberdade de iniciativa do investidor de seu país da maneira abrangente, estabelecendo condições desejáveis de competitividade internacional do investimento. Para o cálculo do IFE temos que 
(i) $\quad$ IFE $=(E+R+C)$

(ii) IFEmáx $=(3+8+4)=15$

(iii) IFEmáx $=P V J$

3.1.6 Avaliação dos resultados em termos de verificação da efetividade ou falhas ou ausência de efetividade

Para avaliar os diferentes tipos de regime de seguro de investimentos, este trabalho se beneficia enormemente da catalogação realizada por Kathryn Gordon (2008) sob os auspícios da OCDE. À época, foram analisadas diferentes características de regimes geridos por agências estatais. Apenas as características já quantificadas acima serão explicitadas aqui, na medida em que outras características trabalhadas por Gordon não impactam necessariamente a fruição do direito de produção apresentado, mas dizem respeito apenas ao modelo de gestão do regime (natureza jurídica da agência, monitoramento, transparência etc). Os dados colhidos por Gordon foram checados, para fins de atualização, nos sítios oficiais das mencionadas agências e nos relatórios financeiros por elas publicados. Em alguns casos, artigos específicos sobre um ou outro regime também foram consultados para identificação de uma dada característica de regime.

Todos os procedimentos de quantificação e mensuração têm o caráter de um exercício para fins de demonstrar como a análise jurídica pode se dar de modo diferente de abordagens mais convencionais; portanto, várias convenções necessitam ser estabelecidas. Quando as características das três dimensões (elegibilidade, riscos cobertos e compliance) não estavam explicitamente identificadas no texto legal, considerou-se ausente a característica.

Para fins de cálculo do IFE, apresenta-se o teor da legislação vetada:

“Art. $6^{\circ}$ A União poderá conceder seguro de investimento no exterior contra riscos políticos e extraordinários.

(...)

Art. $7^{\circ}$ São suscetíveis de cobertura os investimentos brasileiros no exterior, definidos como a participação, direta ou indireta, por parte de empresa brasileira, em empresa constituída fora do Brasil, com o objetivo de estabelecer relações econômicas de longo prazo. 
$\S 1^{\circ}$ A cobertura poderá incluir os empréstimos obtidos junto a instituições financeiras, nacionais ou estrangeiras, para a realização dos investimentos.

$\S 2^{\circ}$ o regulamento desta lei disporá sobre as espécies de investimentos brasileiros diretos no exterior passíveis de cobertura, bem como o prazo mínimo dos investimentos para fins do caput.

Art. $8^{\circ}$ Consideram-se riscos políticos e extraordinários a ocorrência, isolada ou cumulativa, das seguintes situações:

I - ato ou decisão de autoridades estrangeiras que resultem na desapropriação, nacionalização, confisco, sequestro, requisição, ou outras medidas de efeito equivalente, desde que haja comprovação de prejuízo financeiro;

II - a rescisão contratual pelo governo do país de destino, sem culpa do garantido, esgotados os mecanismos acordados de solução de controvérsias;

III - decisões políticas ou dificuldades econômicas no país estrangeiro que resultem na impossibilidade de transferência e convertibilidade de divisas, inclusive a moratória geral decretada por autoridades estrangeiras;

IV - guerra, revolução ou motim no país estrangeiro.

Art. $9^{\circ}$ Às operações de seguro de investimento no exterior com garantia da cobertura da União não se aplicam as limitações contidas no $\operatorname{art}^{\circ}$ da Lei $\mathrm{n}^{\circ} 5.627$, de $1^{\circ}$ de dezembro de 1970 , nem as disposições do Decreto-Lei $\mathrm{n}^{\circ} 73$, de 21 de novembro de 1966.

Art. $10^{\circ}$ Nas operações de seguro de investimento no exterior não serão devidas comissões de corretagem.

As informações contidas nos artigos acima podem ser analisadas à luz das dimensões apresentadas na subseção 3.1.3 deste trabalho. As respostas encontradas, por sua vez, são pontuadas em conformidade com o já mencionado uso da variável dummy. Assim, $\mathrm{O}$ resultado dessa análise pode ser sintetizado na tabela 7 a seguir, e permite encontrar o Índice de Fruição Empírica (IFE) para o projeto de lei vetado. 
Tabela 7: Cálculo do Índice de Fruição Empírica (IFE) - Projeto de Lei vetado

\begin{tabular}{|c|c|c|}
\hline Dimensões & PL dispõe sobre o Assunto? & Resultado \\
\hline Empresas Nacionais $\left(\mathrm{E}_{1}\right)$ & Sim & 1 \\
\hline $\begin{array}{l}\text { Empresas estrangeiras estabelecidas no território } \\
\text { nacional }\left(E_{2}\right)\end{array}$ & Sim & 1 \\
\hline $\begin{array}{l}\text { Subsidiárias estrangeiras de empresas nacionais } \\
\left(\mathrm{E}_{3}\right)\end{array}$ & Não & 0 \\
\hline Elegibilidade $(\mathbf{E})$ final & - & 2 \\
\hline $\begin{array}{l}\text { Cobertura contra risco de inconvertibilidade e } \\
\text { restrições de transferência }\left(R_{1}\right)\end{array}$ & Sim & 1 \\
\hline $\begin{array}{l}\text { Cobertura contra risco de confisco ou } \\
\text { expropriação direta }\left(R_{2}\right)\end{array}$ & Sim & 1 \\
\hline Cobertura contra Expropriação Indireta $\left(\mathrm{R}_{3}\right)$ & Não & 0 \\
\hline $\begin{array}{l}\text { Cobertura contra não cumprimento de obrigações } \\
\text { do governo hospedeiro (empréstimos, cláusulas } \\
\text { contratuais etc) }\left(\mathrm{R}_{4}\right)\end{array}$ & Sim & 1 \\
\hline $\begin{array}{l}\text { Cobertura contra Guerra e eventos congêneres de } \\
\text { violência política }\left(R_{5}\right)\end{array}$ & Sim & 1 \\
\hline Cobertura contra Terrorismo $\left(\mathrm{R}_{6}\right)$ & Sim & 1 \\
\hline $\begin{array}{l}\text { Cobertura contra variação cambial decorrente de } \\
\text { leis internas do país hospedeiro }\left(\mathrm{R}_{7}\right)\end{array}$ & Não & 0 \\
\hline $\begin{array}{l}\text { Cobertura contra riscos extraordinários ou force } \\
\text { majeure }\left(\mathrm{R}_{8}\right)\end{array}$ & $\begin{array}{l}\text { Não (apesar de falar em riscos } \\
\text { extraordinários no caput do art. } \\
\text { 8o }^{\circ} \text { esse risco não é especificado } \\
\text { nos incisos) }\end{array}$ & 0 \\
\hline Nível da Proteção de Riscos (R) final & - & 5 \\
\hline Compliance Social $\left(\mathrm{C}_{1}\right)$ & Não & 0 \\
\hline Compliance Ambiental $\left(\mathrm{C}_{2}\right)$ & Não & 0 \\
\hline Compliance anticorrupção $\left(\mathrm{C}_{3}\right)$ & Não & 0 \\
\hline Compliance trabalhista $\left(\mathrm{C}_{4}\right)$ & Não & 0 \\
\hline Conformidade $(C)$ final & - & 0 \\
\hline IFE & - & 6 \\
\hline
\end{tabular}

Fonte: Elaboração própria

Após verificação do IFE brasileiro - vale lembrar que se trata de uma análise baseada em um projeto de lei -, busca-se a comparação com os regimes já existentes, catalogados por Gordon (2008) e atualizados quanto às características objeto de avaliação neste trabalho. 
Tabela 8: Cálculo do Índice de Fruição Empírica - regimes estrangeiros

\begin{tabular}{|c|c|c|c|c|c|c|c|c|}
\hline $\begin{array}{l}\text { Dimensões / } \\
\text { agência }\end{array}$ & EFIC (Australia) & OEKB (Áustria) & $\begin{array}{c}\text { Delcredere } \\
\text { (Bélgica) }\end{array}$ & $\begin{array}{l}\text { COFACE } \\
\text { (França) }\end{array}$ & $\begin{array}{c}\text { PWC/Euler } \\
\text { Hermes } \\
\text { (Alemanha) }\end{array}$ & SACE (Itália) & $\begin{array}{l}\text { ATRADIUS } \\
\text { (Holanda) }\end{array}$ & EDC (Canadá) \\
\hline $\mathrm{E}_{1}$ & $\operatorname{Sim}(1)$ & $\operatorname{Sim}(1)$ & $\operatorname{Sim}(1)$ & $\operatorname{Sim}(1)$ & $\operatorname{Sim}(1)$ & $\operatorname{Sim}(1)$ & $\operatorname{Sim}(1)$ & $\operatorname{Sim}(1)$ \\
\hline $\mathrm{E}_{2}$ & $\operatorname{Sim}(1)$ & $\operatorname{Sim}(1)$ & $\operatorname{Sim}(1)$ & $\operatorname{Sim}(1)$ & Não (0) & Não consta $(0)$ & $\operatorname{Sim}(1)$ & Não consta $(0)$ \\
\hline $\mathrm{E}_{3}$ & Não (0) & Não (0) & $\operatorname{Sim}(1)$ & Não (0) & $\operatorname{Sim}(1)$ & $\operatorname{Sim}(1)$ & Não (0) & $\operatorname{Sim}(1)$ \\
\hline (E) final & 2 & 2 & 3 & 2 & 2 & 2 & 2 & 2 \\
\hline $\mathrm{R}_{1}$ & $\operatorname{Sim}(1)$ & $\operatorname{Sim}(1)$ & $\operatorname{Sim}(1)$ & $\operatorname{Sim}(1)$ & $\operatorname{Sim}(1)$ & $\operatorname{Sim}(1)$ & $\operatorname{Sim}(1)$ & $\operatorname{Sim}(1)$ \\
\hline $\mathrm{R}_{2}$ & $\operatorname{Sim}(1)$ & $\operatorname{Sim}(1)$ & $\operatorname{Sim}(1)$ & $\operatorname{Sim}(1)$ & $\operatorname{Sim}(1)$ & $\operatorname{Sim}(1)$ & $\operatorname{Sim}(1)$ & $\operatorname{Sim}(1)$ \\
\hline $\mathrm{R}_{3}$ & Não consta $(0)$ & $\operatorname{Sim}(1)$ & $\operatorname{Sim}(1)$ & $\operatorname{Sim}(1)$ & $\operatorname{Sim}(1)$ & $\operatorname{Sim}(1)$ & $\operatorname{Sim}(1)$ & $\operatorname{Sim}(1)$ \\
\hline $\mathrm{R}_{4}$ & Não consta (0) & $\operatorname{Sim}(1)$ & $\operatorname{Sim}(1)$ & Não consta $(0)$ & $\operatorname{Sim}(1)$ & $\operatorname{Sim}(1)$ & $\operatorname{Sim}(1)$ & $\operatorname{Sim}(1)$ \\
\hline $\mathrm{R}_{5}$ & $\operatorname{Sim}(1)$ & $\operatorname{Sim}(1)$ & $\operatorname{Sim}(1)$ & $\operatorname{Sim}(1)$ & $\operatorname{Sim}(1)$ & $\operatorname{Sim}(1)$ & $\operatorname{Sim}(1)$ & $\operatorname{Sim}(1)$ \\
\hline $\mathrm{R}_{6}$ & Não consta (0) & Não consta $(0)$ & Não consta (0) & $\operatorname{Sim}(1)$ & $\operatorname{Sim}(1)$ & $\operatorname{Sim}(1)$ & Não consta $(0)$ & Não consta $(0)$ \\
\hline $\mathrm{R}_{7}$ & Não consta $(0)$ & Não consta $(0)$ & Não consta (0) & Não consta (0) & Não consta $(0)$ & Não consta (0) & Não consta $(0)$ & Não consta $(0)$ \\
\hline $\mathrm{R}_{8}$ & Não consta (0) & Não consta (0) & Não consta (0) & Não consta $(0)$ & Não consta $(0)$ & $\operatorname{Sim}(1)$ & $\operatorname{Sim}(1)$ & Não consta $(0)$ \\
\hline (R) final & 3 & 5 & 5 & 5 & 6 & 7 & 6 & 5 \\
\hline $\mathrm{C}_{1}$ & $\operatorname{Sim}(1)$ & $\operatorname{Sim}(1)$ & $\operatorname{Sim}(1)$ & $\operatorname{Sim}(1)$ & Não consta $(0)$ & Não consta $(0)$ & $\operatorname{Sim}(1)$ & Não consta $(0)$ \\
\hline $\mathrm{C}_{2}$ & $\operatorname{Sim}(1)$ & $\operatorname{Sim}(1)$ & $\operatorname{Sim}(1)$ & Não consta $(0)$ & $\operatorname{Sim}(1)$ & $\operatorname{Sim}(1)$ & $\operatorname{Sim}(1)$ & $\operatorname{Sim}(1)$ \\
\hline $\mathrm{C}_{3}$ & Não consta $(0)$ & $\operatorname{Sim}(1)$ & $\operatorname{Sim}(1)$ & $\operatorname{Sim}(1)$ & Não consta $(0)$ & Não consta $(0)$ & $\operatorname{Sim}(1)$ & $\operatorname{Sim}(1)$ \\
\hline $\mathrm{C}_{4}$ & $\operatorname{Sim}(1)$ & Não consta (0) & $\operatorname{Sim}(1)$ & Não consta (0) & Não consta $(0)$ & Não consta (0) & $\operatorname{Sim}(1)$ & Não consta $(0)$ \\
\hline (C) final & 3 & 3 & 4 & 2 & 1 & 1 & 4 & 2 \\
\hline IFE estrangeiro & 8 & 10 & 12 & 9 & 9 & 10 & 12 & 9 \\
\hline
\end{tabular}




\begin{tabular}{|c|c|c|c|c|c|c|c|c|}
\hline $\begin{array}{l}\text { Dimensões/ } \\
\text { Agência }\end{array}$ & OPIC (EUA) & ECGC (India) & $\begin{array}{c}\text { ECIC (África do } \\
\text { Sul) }\end{array}$ & NEXI (Japão) & KEIC (Coreia) & $\begin{array}{l}\text { ECGD/UKEF } \\
\text { (Reino Unido) }\end{array}$ & Sinosure (China) & $\begin{array}{l}\text { MIGA (Banco } \\
\text { Mundial) }\end{array}$ \\
\hline $\mathrm{E}_{1}$ & $\operatorname{Sim}(1)$ & $\operatorname{Sim}(1)$ & $\operatorname{Sim}(1)$ & $\operatorname{Sim}(1)$ & $\operatorname{Sim}(1)$ & $\operatorname{Sim}(1)$ & $\operatorname{Sim}(1)$ & $\operatorname{Sim}(1)$ \\
\hline$E_{2}$ & Não (0) & Não (0) & Não (0) & Não (0) & Não (0) & $\operatorname{Sim}(1)$ & Não (0) & $\operatorname{Sim}(1)$ \\
\hline $\mathrm{E}_{3}$ & $\operatorname{Sim}(1)$ & Não (0) & Não (0) & Não (0) & Não (0) & $\operatorname{Sim}(1)$ & Não (0) & $\operatorname{Sim}(1)$ \\
\hline (E) final & 2 & 1 & 1 & 1 & 1 & 3 & 1 & 3 \\
\hline $\mathrm{R}_{1}$ & $\operatorname{Sim}(1)$ & $\operatorname{Sim}(1)$ & $\operatorname{Sim}(1)$ & $\operatorname{Sim}(1)$ & $\operatorname{Sim}(1)$ & $\operatorname{Sim}(1)$ & $\operatorname{Sim}(1)$ & $\operatorname{Sim}(1)$ \\
\hline $\mathrm{R}_{2}$ & $\operatorname{Sim}(1)$ & $\operatorname{Sim}(1)$ & $\operatorname{Sim}(1)$ & $\operatorname{Sim}(1)$ & $\operatorname{Sim}(1)$ & $\operatorname{Sim}(1)$ & $\operatorname{Sim}(1)$ & Sim (1) \\
\hline $\mathrm{R}_{3}$ & $\operatorname{Sim}(1)$ & Não (0) & Sim (1) & Não consta $(0)$ & Não consta (0) & Não consta (0) & Não consta $(0)$ & $\operatorname{Sim}(1)$ \\
\hline $\mathrm{R}_{4}$ & $\operatorname{Sim}(1)$ & Não consta (0) & $\operatorname{Sim}(1)$ & $\operatorname{Sim}(1)$ & $\operatorname{Sim}(1)$ & $\operatorname{Sim}(1)$ & $\operatorname{Sim}(1)$ & $\operatorname{Sim}(1)$ \\
\hline $\mathrm{R}_{5}$ & $\operatorname{Sim}(1)$ & $\operatorname{Sim}(1)$ & $\operatorname{Sim}(1)$ & $\operatorname{Sim}(1)$ & $\operatorname{Sim}(1)$ & $\operatorname{Sim}(1)$ & $\operatorname{Sim}(1)$ & $\operatorname{Sim}(1)$ \\
\hline $\mathrm{R}_{6}$ & $\operatorname{Sim}(1)$ & Não consta (0) & Não consta $(0)$ & $\operatorname{Sim}(1)$ & Não consta (0) & Não consta (0) & Não consta $(0)$ & $\operatorname{Sim}(1)$ \\
\hline $\mathrm{R}_{7}$ & Não Consta (0) & $\operatorname{Sim}(1)$ & Não consta $(0)$ & Não consta $(0)$ & Não consta (0) & Não consta $(0)$ & Não consta $(0)$ & Não consta $(0)$ \\
\hline $\mathrm{R}_{8}$ & Não (0) & Não consta $(0)$ & Não consta $(0)$ & $\operatorname{Sim}(1)$ & Não consta (0) & Não consta (0) & Não consta $(0)$ & Não consta $(0)$ \\
\hline (R) final & 6 & 4 & 5 & 6 & 4 & 4 & 4 & 6 \\
\hline $\mathrm{C}_{1}$ & $\operatorname{Sim}(1)$ & Não consta (0) & Não consta $(0)$ & $\operatorname{Sim}(1)$ & Não consta (0) & $\operatorname{Sim}(1)$ & $\operatorname{Sim}(1)$ & $\operatorname{Sim}(1)$ \\
\hline $\mathrm{C}_{2}$ & $\operatorname{Sim}(1)$ & Não consta (0) & Não consta $(0)$ & $\operatorname{Sim}(1)$ & Não consta (0) & $\operatorname{Sim}(1)$ & $\operatorname{Sim}(1)$ & $\operatorname{Sim}(1)$ \\
\hline $\mathrm{C}_{3}$ & $\operatorname{Sim}(1)$ & Não consta $(0)$ & Não consta $(0)$ & Não consta $(0)$ & Não consta $(0)$ & $\operatorname{Sim}(1)$ & Não consta $(0)$ & Não consta $(0)$ \\
\hline $\mathrm{C}_{4}$ & $\operatorname{Sim}(1)$ & Não consta $(0)$ & Não consta $(0)$ & Não consta $(0)$ & Não consta $(0)$ & $\operatorname{Sim}(1)$ & $\operatorname{Sim}(1)$ & $\operatorname{Sim}(1)$ \\
\hline (C) final & 4 & $\mathbf{0}$ & 0 & 2 & 0 & 4 & 3 & 3 \\
\hline IFE estrangeiro & 12 & 5 & 6 & 9 & 5 & 11 & 8 & 12 \\
\hline
\end{tabular}

Fonte: Gordon (2008): Elaboração própria 
Ao ranquearmos os IFEs encontrados, o resultado é o seguinte:

Tabela 9: Ranking dos IFEs encontrados nas tabelas 7 e 8

\begin{tabular}{ccc}
\hline Posição & Agência/País & IFE \\
\hline $1^{\mathbf{o}}$ & Delcredere/Bélgica & 12 \\
\hline $1^{\mathbf{o}}$ & Atradius/Holanda & 12 \\
\hline $1^{\mathbf{o}}$ & OPIC/EUA & 12 \\
\hline $1^{\mathbf{o}}$ & Miga/Banco Mundial & 12 \\
\hline $2^{\mathbf{o}}$ & ECGD-UKEF/Reino Unido & 11 \\
\hline $3^{\mathbf{o}}$ & OEKB/Áustria & 10 \\
\hline $3^{\mathbf{o}}$ & SACE/Itália & 10 \\
\hline $4^{\mathbf{o}}$ & Coface/França & 9 \\
\hline $4^{\mathbf{o}}$ & PWC-Euler Hermes/Alemanha & 9 \\
\hline $4^{\mathbf{0}}$ & Nexi/Japão & 9 \\
\hline $4^{\mathbf{o}}$ & EDC/Canadá & 8 \\
\hline $5^{\mathbf{0}}$ & Sinosure/China & 8 \\
\hline $5^{\mathbf{0}}$ & Efic/Austrália & $\mathbf{7}$ \\
\hline $\mathbf{6}^{\mathbf{0}}$ & Brasil*(projeto vetado) & 6 \\
\hline $7^{\mathbf{0}}$ & ECIC/África do Sul & 5 \\
\hline $8^{\mathbf{o}}$ & KEIC/Coréia & 5 \\
\hline $8^{\mathbf{o}}$ & ECGC/Índia & 9 \\
\hline
\end{tabular}

Elaboração própria

O projeto brasileiro, caso resultasse em lei, decerto traria benefícios aos investidores nacionais, já que permitiria a contratação de um seguro antes inexistente. No entanto, com base na análise comparativa acima, realizada de acordo com a metodologia da AJPE, é possível assumir que o regime brasileiro não proporcionaria condições de suficiente efetividade do direito de propriedade comercial de investidores brasileiros, de modo a tornar os seus investimentos competitivos, consideradas as condições de que se beneficiam investidores estrangeiros, notadamente aqueles dos países desenvolvidos. Conforme indica a análise acima, a fruição do direito de produção atinge degrau mais elevado no caso das políticas de países estrangeiros em decorrência dos seguintes fatores: (i) os critérios de elegibilidade costumam ser mais amplos (protegem-se tanto o made in como o made by), (ii) uma variedade maior de riscos é coberto e (iii) a concessão do seguro passa pela aprovação de alguns parâmetros de responsabilidade, tais como medidas anticorrupção e critérios socioambientais ou trabalhistas.

Naturalmente, se, de um lado, cada variável existente representa um nível a mais de fruição no direito de produção, também é certo presumir que esse aumento de fruição pode implicar um aumento do custo de gestão do seguro. Por exemplo, a realização de 
procedimentos de compliance demanda equipe técnica especializada e custo operacional. É razoável crer, também, que cada aumento de custo estrutural na gestão do seguro implicaria uma majoração nos custos da agência e, consequentemente, uma necessidade de inclusão desse passivo no modelo geral de precificação do risco. Simplificando: havendo maiores custos, maior deverá ser o prêmio cobrado do investidor.

Tomando por pressuposto que a cobrança do prêmio não deve ser de tal monta que inviabilize a contratação do próprio seguro, este autor não defende a reformulação geral do projeto de lei, a fim de que ele atinja um IFE $=15$. As alterações devem, sim, ocorrer, mas de maneira pontual, a fim de conferir ao seguro brasileiro características institucionais capazes de proporcionar, aos empresários nacionais que investem no estrangeiro, um nível de fruição equivalente aos existentes em outros países para empresários estrangeiros. O que se propõe, então?

Em primeiro lugar, que o governo brasileiro também estenda a possibilidade de contratação do seguro a subsidiárias brasileiras localizadas no exterior. É preciso reconhecer a importância de filiais brasileiras no exterior e alcançar essas unidades com o apoio oficial. Afinal de contas, elas trocam informações, técnica e conhecimento com as unidades nacionais, bem como, muitas vezes, importam produtos e serviços nacionais. Essa extensão geraria um custo marginal pequeno em relação às possibilidades indiretas de ganhos.

Além disso, o Brasil poderia explicitar, em lei, a proteção contra riscos de expropriação indireta ${ }^{81}$. Os atos populistas de nacionalização, embora ainda ocorrentes, tem sido (até o presente) menos e menos frequentes. Sem embargo, crescem as variedades de atos governamentais que, ainda que não busquem expropriar diretamente uma empresa estrangeira, causam a ela severa diminuição do valor ${ }^{82}$, como políticas tarifárias discriminatórias e regimes de compras públicas, entre outros. A iniciativa brasileira de, no âmbito do Mercosul, negociar no sentido de afastar a proibição de expropriação indireta ${ }^{83}$ baseia-se na garantia de liberdade de políticas públicas. Esse entendimento, todavia, não representa, por si só, um argumento robusto para que o governo brasileiro decida por não reconhecer a existência desse tipo de expropriação. A respeito das expropriações diretas, por

\footnotetext{
${ }^{81}$ A respeito das expropriações indiretas, ver nota de rodapé $\mathrm{n} .34$ acima.

${ }^{82}$ Como exemplo da expropriação indireta do tipo "nacionalização progressiva" (indigenization), LauraCristiana Spătaru-negură e Mihai Spătaru-Negură (2012, p. 825) citam o caso da política pública malaia Bumiputra, de natureza étnica, que determinou que as empresas deveriam ter quotas étnicas em seus quadros de participação acionária de acordo com as raças delimitadas pelo governo nacional, cabendo aos estrangeiros percentagem restrita nessa participação.

${ }^{83}$ A esse respeito conferir subseção 1.2.1.
} 
exemplo, o próprio Estado brasileiro cuida de suas hipóteses na Constituição Federal $^{84}$, o que permite concluir que ela é considerada, em determinados casos, um direito soberano. Nem por isso ela deixa de ser um risco passível de cobertura.

Também é importante notar que o Projeto de Lei vetado, apesar de falar em riscos extraordinários, não trata, de fato, desse tipo de eventos. Assim, enquanto a noção de poltical risk congrega as hipóteses de eventos extraordinários, como maremotos, terremotos, entre outros, a legislação brasileira faz distinção expressa entre riscos políticos e riscos extraordinários. Eventual lei, portanto, teria de tratar especificadamente de cada assunto.

Ademais, o governo brasileiro não deveria omitir-se com respeito a regimes de trabalho análogos à escravidão, desmatamentos desmedidos, deslocamentos não planejados de populações ou enriquecimento ilícito de agentes oficiais estrangeiros. Essas práticas (inclusive em muitos casos por força de compromissos internacionais) devem ser repelidas não somente nas esferas específicas de negociação multilateral, mas devem também ser combatidas por esforços de dissuasão, ou ao menos evitadas de maneira unilateral, a fim de que o país não ganhe uma imagem de exportador de corrupção ou de trabalho escravo, por exemplo.

Caso todas as alterações sugeridas fossem implementadas, o IFE nacional mais que dobraria, saltando de 6 para 13. Mesmo sem atingir o PJV indicado, o regime brasileiro seria certamente competitivo em comparação com os mecanismos nacionais mais robustos de seguro de investimento. Essas sugestões são indicadas no Apêndice deste trabalho, em forma de minuta de projeto de lei.

\footnotetext{
${ }^{84}$ A Constituição Federal prevê a tomada da propriedade pelo Estado em caso de interesse público (art. $5^{\circ}$, XXIV - "a lei estabelecerá o procedimento para desapropriação por necessidade ou utilidade pública, ou por interesse social, mediante justa e prévia indenização em dinheiro, ressalvados os casos previstos nesta Constituição") e como forma de penalidade (Art. 243. "As propriedades rurais e urbanas de qualquer região do País onde forem localizadas culturas ilegais de plantas psicotrópicas ou a exploração de trabalho escravo na forma da lei serão expropriadas e destinadas à reforma agrária e a programas de habitação popular, sem qualquer indenização ao proprietário e sem prejuízo de outras sanções previstas em lei, observado, no que couber, o disposto no art. $5^{\circ}$ ")
} 


\section{CONCluSÃo}

Conforme descrito na Introdução, este trabalho buscou tratar do tema do seguro de investimento, sugerindo a possibilidade de sua criação no ordenamento jurídico brasileiro. Para avaliar como um tal seguro poderia oferecer proteção equivalente àquela ofertada por regimes estrangeiros de seguro de investimento, o trabalho seguiu a metodologia designada Análise Jurídica da Política Econômica.

No primeiro capítulo deste trabalho, buscou-se abordar o tema dos investimentos diretos - definidos como a transferência de recursos da unidade matriz (parent firm) de uma empresa multinacional para uma unidade receptora (host firm) em outro país, com a finalidade de obter controle ou propriedade sobre ativos fora do país de origem. Ao tratarmos das razões pelas quais empresas investem fora de seu país de origem, verificamos uma diversidade de fatores: são exemplos de determinantes para a internacionalização de uma empresa a busca de novos mercados, a internalização de custos de transação, a desoneração de barreiras tarifárias, a aproximação de matérias primas e o aumento de eficiência.

Apresentadas as linhas gerais sobre o conceito de investimentos diretos, o primeiro capítulo também demonstrou que o Brasil é um importante receptor de investimentos externos, posicionando-se comumente na lista dos dez países que mais hospedam investimentos ano a ano. As últimas décadas, no entanto, testemunharam um enorme crescimento de investimentos brasileiros realizados no exterior. Especificamente nos últimos 15 anos, o estoque de investimentos brasileiros diretos no exterior saiu de um patamar de quase US\$ 50 bilhões para alcançar aproximadamente US\$ 300 bilhões, crescimento seguramente robusto, mas ainda não compatível com o tamanho da economia brasileira.

Como causa do desequilíbrio acima mencionado, procurou-se argumentar que a estrutura governamental desenhada para fomentar a internacionalização de empresas brasileiras ainda é muito menos robusta do que aquela desenhada para estimular o caminho inverso, a saber, o conjunto de políticas públicas voltadas à atração de investimentos estrangeiros ao Brasil. O trabalho indica que uma política de promoção de investimentos no exterior deveria calcar-se em, pelo menos, três pilares: a) o fomento à assinatura de tratados de investimento, que estabeleçam mecanismos mútuos de facilitação e diminuir custos de transação entre Estados de forma preventiva; b) o aumento de iniciativas de financiamento à internacionalização no exterior, o que significaria um avanço em relação ao financiamento à exportação; c) o estabelecimento de mecanismos nacionais de garantias, com o objetivo de 
compensar, de maneira tempestiva e eficaz, investidores nacionais que sofram medidas governamentais emanadas do Estado receptor e tendentes a afetar negativamente o investimento.

A respeito dos tratados de investimento, somente muito recentemente, a partir do segundo governo Dilma, o Brasil consolidou uma orientação a respeito do tema, a qual culminou no modelo de tratado intitulado Acordo de Cooperação e Facilitação de Investimentos (ACFI). Esse modelo tem sido utilizado nos ciclos mais recentes de negociação bilateral. Apesar do esforço do governo brasileiro, o número de acordos assinados - apenas sete, até o fechamento deste trabalho - ainda é insuficiente quando considerada a diversidade de países em relação aos quais o Brasil projeta interesses econômicos. Ademais, algumas contrapartes não são economicamente representativas para a estratégia nacional. Por fim, nenhum dos acordos já vigora, uma situação a demonstrar a precariedade desse alicerce estatal para uma boa política de promoção de investimentos.

Em relação aos mecanismos de financiamento, discutiu-se que o modelo brasileiro de financiamento de longo prazo tem participação predominante de bancos públicos. Apesar de ter havido, notadamente nos anos 2000, um ciclo importante de apoio do principal banco de desenvolvimento brasileiro à internacionalização de empresas brasileiras, os últimos anos indicaram um redimensionamento - a menor - dessa política.

Ao final do primeiro capítulo, ressalva-se a criação, no final de 2016, do chamado Comitê Nacional de Investimentos (Coninv) no âmbito da Câmara de Comércio Exterior (CAMEX). O comitê visa formular "propostas e recomendações à CAMEX voltadas ao fomento e à facilitação de Investimentos Estrangeiros Diretos (IED) no País e de Investimentos Brasileiros Diretos no Exterior (IBDE)". Apesar de as atribuições do Coninv abrangerem explicitamente, políticas de promoção de investimentos brasileiros no exterior, sua criação recente ainda não permite analisar o possível sucesso dessa iniciativa governamental.

No segundo Capítulo, tentou-se abordar, de maneira interdisciplinar, o tema específico do seguro de investimento no exterior, objeto central desta dissertação. Conforme se buscou demonstrar, diversos países criaram, no âmbito de agências especializadas e pelo menos desde a década de 1970, os seguros de investimento no exterior, com a intenção de corrigir falhas de mercado. Esse seguro consiste numa garantia fornecida a um investidor contra perdas de investimento realizado em um país estrangeiro, resultantes atos de natureza política ou extraordinária. Defendeu-se que esses seguros podem ser considerados como um novo modelo de "proteção diplomática", modalidade de atuação estatal conhecida no Direito 
Internacional como a proteção que um país oferece em favor de um nacional seu que se encontre em litígio em outro Estado, de maneira que a relação da disputa deixe de ser investidor-Estado e passe a ser Estado-Estado.

Em razão do seu nível de competitividade, as empresas brasileiras tendem a encontrar maior sucesso em suas tentativas de internacionalização em outros países em desenvolvimento. Nesses casos, é possível encontrar amarras regulatórias mais frouxas e uma concorrência menos severa, a permitir que as empresas entrantes se adaptem com menos dificuldade a um novo mercado. Esses atrativos, no entanto, são relativizados pela constatação de que os países em desenvolvimento apresentam maiores riscos políticos a iniciativas empresariais de outros países. Segundo dados da Berne Union, associação de agências de crédito à exportação e de seguros de investimentos, a maior parte das indenizações pagas em contratos de seguros de investimentos no período 2011-2015 foi destinada a reparar sinistros de natureza política ocorridos justamente em países em desenvolvimento.

Em 2016, o Congresso Brasileiro propôs a criação, durante a tramitação de uma Medida Provisória, de um seguro de investimentos brasileiros no exterior, o qual seria lastreado em um fundo público já existente para lastrear operações de crédito à exportação, o Fundo de Garantia à Exportação (FGE). A iniciativa, apesar de contar com o apoio do Congresso, foi vetada na fase de sanção presidencial. A mensagem de veto $\mathrm{n}^{\circ} 304$, de 31 de maio de 2016, indicava que o seguro de investimentos elevaria "sobremaneira o risco potencial do FGE e, com isso, podendo gerar possíveis impactos fiscais relevantes à União".

Conforme se expôs no Capítulo 3 do trabalho, a tentativa malsucedida de criação de um seguro de investimento no exterior indica divergência a respeito desse instrumento de política econômica. Essa iniciativa estatal, ainda que não transformada em lei, pode ser avaliada no que se refere à efetividade dos direitos (propriedade comercial dos investidores), caso fosse instituído. Para fins dessa análise, o autor se valeu da metodologia e do marco teórico fornecidos pela chamada "Análise Jurídica da Política Econômica (AJPE)”, a qual “considera a política econômica como conjunto de regras politicamente instituídas que organizam a produção, a troca e o consumo na vida social” (CASTRO, 2009, p. 22).

No desenvolvimento do Capítulo 3, fez-se uso do procedimento analítico proposto por Castro para a "análise posicional” de uma determinada política econômica, consistente nas seguintes etapas: “a) identificação de política pública ou econômica (ou componente de política pública ou econômica sujeita a controvérsias. b) Especificação de direito fundamental correlato. c) Decomposição analítica do(s) direito (s). d) Quantificação dos 
direitos analiticamente decompostos. e) Elaboração de índice de fruição empírica (IFE). f) Escolha ou elaboração de 'padrão de validação jurídica' (PVJ). g) Avaliação dos resultados em termos de verificação da efetividade ou falhas ou ausência de efetividade. h) Na hipótese de falha ou ausência de efetividade, elaboração de recomendações de reformas" (CASTRO, 2009, p. 41-45).

A política econômica estudada é o conjunto de regras adotadas pelo estado Brasileiro para estruturar o seguro de investimento de empresas brasileiras no exterior. No Brasil, por ainda não existir regime ou conjunto de regras em vigor nessa área, a PSIE é ainda "de lege ferenda", ou seja, tem atualmente, a feição de proposta de política pública.

Ao tratar da especificação do direito fundamental, Castro $(2009$, p. 50) levanta a necessidade de que a natureza de produção ou de consumo do direito seja identificada, na medida em que há diferentes dimensões de análise a serem consideradas, a depender de um outro tipo de direito. Castro (idem) ainda estipula que os "direitos de produção" correspondem às "formas de propriedade com função produtiva", que contrastam, portanto, com a propriedade civil, dotada de função primária de consumo. O presente trabalho argumentou que o seguro de investimento (ou sua ausência) impacta a fruição de um direito de produção, a saber, o direito de propriedade comercial de titulares brasileiros, que se reflete na configuração institucional da própria liberdade de iniciativa da atividade empresarial, no contexto da economia internacional.

No que concerne à decomposição analítica do direito, foram selecionados aspectos de proteção que possam favorecer a fruição de direitos de produção em conexão com a implementação de um seguro de investimento no exterior. Assim, a decomposição exigiu a identificação de características relevantes da política focalizada, que pudessem influenciar a fruição do direito de produção (a propriedade comercial de empresários brasileiros), considerada a existência de um regime de seguro de investimento. Conforme dito ao longo do trabalho, um regime pode ser mais, ou menos, protetor que outro, no sentido de garantir mais, ou menos, a efetividade do direito de iniciativa privada (ou propriedade comercial). Nesse sentido, foram identificadas três dimensões relativas a diferentes níveis de proteção do seguro de investimento: a elegibilidade do investimento, os tipos de risco cobertos pelo seguro e a conformidade com parâmetros normativos socioambientais, trabalhistas e éticos. Essas dimensões foram detalhadas na subseção 3.1.3 deste trabalho.

O índice de fruição empírica (IFE) permitiu a caracterização, em números, dos aspectos de fruição do direito pesquisado, tanto em relação à proposta legal vetada no ordenamento brasileiro, quanto em relação a outros quatorze regimes estrangeiros Por sua 
vez, o padrão de validação jurídica (PVJ) foi considerado uma projeção equivalente a um IFE “otimizado". Todos os procedimentos de quantificação e mensuração tiveram o caráter de um exercício para fins de demonstrar como a análise jurídica pode se dar de modo diferente de abordagens mais convencionais. Os resultados encontrados indicaram uma disparidade relevante entre a proposta de regime brasileiro e os regimes já estabelecidos em outros países.

De acordo com os resultados encontrados nas tabelas 7, 8 e 9 deste trabalho, o regime brasileiro, caso aprovado nos moldes propostos pelo Congresso Nacional, não proporcionaria a mesma fruição de direito de que gozam outros investidores estrangeiros, notadamente aqueles dos países desenvolvidos. Notou-se que a fruição do direito de produção atinge degrau mais elevado no caso das políticas de países estrangeiros porque os critérios de elegibilidade costumam ser mais amplos há uma variedade maior de riscos cobertos e a concessão do seguro passa pela aprovação de alguns parâmetros de responsabilidade, tais como medidas anticorrupção e critérios socioambientais ou trabalhista.

Em sede de sugestões, mostrou-se que o Projeto de lei poderia ser modificado, a fim de aumentar a fruição de direitos de produção por parte do investidor brasileiro. Medidas pontuais na elegibilidade de contratação do programa, nos tipos de riscos passíveis de cobertura e na necessidade de comprovação de conformidade socioambiental, trabalhista e anticorrupção permitiria que um regime brasileiro alcançasse níveis de proteção equivalentes aos oferecidos pelos governos estrangeiros.

Como último comentário, frisamos que a presente pesquisa de modo algum teve o objetivo de exaurir o tema. Ao contrário, espera-se que sua leitura permita a abertura de novas frentes de pesquisa a respeito do seguro de investimento. Várias possibilidades de investigação teórica surgem, seja no âmbito do direito (como o estudo da proposta do regime sob a ótica empresarial, pesquisas sobre entendimentos de litígios de investimentos em casos arbitrais etc.) ou mesmo sob outros campos teóricos, como o das relações internacionais (a internacionalização de empresas e a projeção dos interesses brasileiros no exterior), ou mesmo os da economia e das finanças (estudos microeconômicos sobre eventuais impactos, benefícios e desafios financeiros para a implantação de um regime de seguro de investimentos), entre outros. 


\section{REFERÊNCIAS BIBLIOGRÁFICAS}

ALBRES, Hevellyn Menezes. A construção da governança transnacional da responsabilidade social empresarial: a implementação no Brasil. Dissertação de Mestrado. Instituto de Relações Internacionais da Universidade de Brasília, 2014.

ALEM, Ana Cláudia; Cavalcanti, Carlos Eduardo. O BNDES e o apoio à internacionalização das empresas brasileiras: algumas reflexões. Revista do BNDES, vol. 12, $\mathrm{n}^{\circ} 24$. Rio de Janeiro, 2005.

ALLEN, R. Michael; VISCUSI, W. Kip. Insuring the Expropriation Risks of Multinational Firms. Stanford Journal of International Studies II. 1976, pp. 153-168.

ANDRADE, Thiago Pedroso de. Expropriação no Direito Internacional do Investimento: ponto de vista do Direito Brasileiro. Dissertação de Mestrado - Faculdade de Direito, Universidade Católica de Santos, 2008.

Aspectos metodológicos do direito internacional do investimento. 2015.

Tese (Doutorado em Direito Internacional) - Faculdade de Direito, Universidade de São Paulo, São Paulo, 2015. doi:10.11606/T.2.2015.tde-15122015-133808. Acesso em: 2016-1214.

ARON, Raymond. Paz e Guerra entre as Nações. Coleção Clássicos IPRI. São Paulo: Editora Universidade de Brasília, 2002.

AZPIAZU, Daniel, Privatización del agua y el saneamiento en Argentina: El caso paradigmático de Aguas Argentinas S.A. Vertigo - la revue électronique en sciences de l'environnement, Hors série 7, Disponível em http://vertigo.revues.org/9730. Acesso em 10.02.2017

BADINGER, Harald; URL, Thomas. Export Credit Guarantees and Export Performance: Evidence from Austrian Firm-Level Data. WIFO Working Papers, No. 423, March. 2012.

BARRETO, Fernando de Mello. O tratamento nacional dos investimentos estrangeiros. Coleção Curso de Altos Estudos do Instituto Rio Branco. Brasília: Editora Fundação Alexandre de Gusmão, 1999.

A política Externa após a redemocratização. Tomo II - 2003-2010. Brasília: Fundação Alexandre de Gusmão, 2012.

BAUMANN, Renato. GONÇALVES, Reinaldo. Economia Internacional: teoria e experiência brasileira. Rio de Janeiro: Elsevier, 2015.

BORGES, Henrique Souza. Aspectos jurídicos da regulação dos mercados financeiros: desafios contemporâneos. Monografia (Bacharelado em Direito) - Universidade de Brasília, Brasília, 2015. Disponível em http://bdm.unb.br/handle/10483/11762. Acesso em 29/08/2016. 
CALDERÓN, Alma Alicia Bezares. Outward FDI in Brazil. A matter of economic growth and institutional configuration. Prepared for the FLACSO-ISA Joint International Conference in Buenos Aires, Argentina July 23-25, 2014.

CARVALHO, Vinicius Marques de; CASTRO, Ricardo Medeiro de. Política Industrial, campeões nacionais e antitustre sob a perspectiva brasileira: uma avaliação crítica. In: SCHAPIRO, Mario Gomes; TRUBEK, David M. (org.). Direito e Desenvolvimento: um diálogo entre os BRICS. São Paulo: Saraiva, pp. 315-349.

CASTELAN, Daniel Ricardo. Acordos de Investimento na América do Sul. Boletim de economia e política internacional/ IPEA, n. 12 (out-dez 2012), pp. 75-94.

CASTRO, José Augusto de. A equalização de taxa de juros e sua função de suporte para a competitividade da exportação brasileira. $R B C E$ vol. 124, Julho/Agosto/Setembro de 2015, pp. 56-61.

CASTRO, Marcus Faro de. Instituições econômicas: evolução de seus elementos constitucionais na sociedade de mercado. Revista de Direito Empresarial, Curitiba, n. 6 $\mathrm{jul} / \mathrm{dez} 2006$.

Análise Jurídica da Política Econômica. Revista da Procuradoria-Geral do Banco Central, v. 3, 2009, p. 17-71

Formas Jurídicas e Mudança Social. Interações entre o Direito, a Filosofia, a Política e a Economia - São Paulo: Saraiva, 2012.

Economic development and the legal foundations of regulation in Brazil. Law and Development Review, De Gruyter, 2013, pp. 61-115.

New Legal Approaches to Policy Reform in Brazil. Direito. Revista de Direito da Universidade de Brasília, v. 1. 2014, p. 31-61.

From Numbers to Post-Logocentric Normative Craft: On the Use of Indicators and Comparable Constructs in Contemporary Legal Analysis" - Trabalho apresentado no 3rd ISA Forum of Sociology (International Sociological Association), Viena, Áustria, 10-14 de Julho, 2016

CHAUFFOUR, Jean-Pierre; SABOROWSKI, Christian; e SOYLEMEZOGLU, Ahmet I. Trade Finance in Crisis: Should Developing Countries Establish Export Credit Agencies? Policy Research Working Paper 5166, 2010.

COELHO, Diego Bonaldo; OLIVEIRA JÚNIOR, Moacir de Miranda. As multinacionais brasileiras e os desafios do Brasil no século XXI. RBCE vol. 110, janeiro/março 2012, pp. 44-57.

COLLINS, David. The BRIC States and Outward Foreign Direct Investment. Oxford University Press, 2013.

CONFEDERAÇÃO NACIONAL DA INDÚSTRIA. Agenda Internacional da Indústria 2016.

Disponível

em 
http://arquivos.portaldaindustria.com.br/app/conteudo_18/2016/06/20/11240/AgendaInterna cional2016_web_201605.pdf

DESROSIÈRES, Alain. Pour une Sociologie Historique de la Quantification: L'Argument Statistique I. Paris: Presses de lÉcole des Mines, 2008.

DUNNING, John. Multinational Enterprises and the Global Economy. Suffolk, Great Britain: Addison-Wesley Publishers, 1992.

FOX, Hazel. The definition and sources of International Economic Law. In International Economic Law and Developing States. Vol 2: an introduction. The British Institute of International and Comparative Law. London, 1992.

GORDON, Kathryn. Investment Guarantees and Political Risk Insurance: Institutions, Incentives and Development. In: OECD. OECD Investment Policy Perspectives 2008. OECD Publishing. Disponível em http://dx.doi.org/10.1787/ipp-208-5-en.

GRATH, Anders. The Handbook of International Trade and Finance. 2. Ed. KroganPage. 2012.

GRAU, Eros Roberto. A ordem econômica na Constituição de 1988. 17 ${ }^{\text {a }}$ Ed. São Paulo: Malheiros, 2015.

IGLESIAS, Roberto Magno; VEIGA, Pedro da Motta. Promoção de Exportações via Internacionalização das Firmas de Capital Brasileiro. In: PINHEIRO, Armando Castelar, MARKWALD, Ricardo; PEREIRA, Lia Valls (orgs). O Desafio das Exportações. Rio de Janeiro: BNDES, 2002, pp. 367-446.

KLASEN, Andreas. Export Credit Guarantees and Demand for Insurance. CESifo Forum 3/2014 (September).

KOLDYK, Daniel; QUINN, Lewis M.; EVANS, Todd. Chasing the Chain: Canada's Pursuit of Global Value Chains. In: TAPP, Stephen; VAN ASSCHE, Ari; WOLFE, Robert (editors). Redesigning Canadian Trade Policies for New Global Realities. Institute for Research on Public Policy (IRPP). 2015, pp. 1-30. Disponível em http://www.edc.ca/EN/Knowledge-Centre/Economic-Analysis-and-

Research/Documents/chasing-the-chain.pdf. Acesso em 15.02.2017.

KRUGMAN, Paul R; OBSTFELD, Maurice. Economia internacional: teoria e política. São Paulo: Pearson Addison Wesley, 2005.

LEONARDI, Renato de Barros de Aguiar. O Sistema Multilateral de investimento e os países em desenvolvimento: desafios e oportunidades. Dissertação de Mestrado. Instituto de Relações Internacionais. Universidade de Brasília, Brasília, 2006.

LIMA, Albério Júnio Rodrigues de. A efetividade do programa microempreendedor individual, com base na análise jurídica da política econômica, em relação ao direito de produção. Dissertação de Mestrado. Faculdade de Direito da Universidade de Brasília, Brasília, 2014. 
MAGALHÃES, José Carlos de. Direito econômico internacional. $1^{\text {a }}$ ed. (2005), $5^{\text {a }}$ reimpressão (2012). Curitiba: Juruá, 2012.

MARTIN, Edwin M. JR. Multilateral Investment Insurance: the OECD Proposal. Harvard International Law Journal 8.2 (1967): 280-338.

MATTOS, Paulo Todescan Lessa. Instituições e investimentos no capitalismo brasileiro. In: COUTINHO, Diogo R.; ROCHA, Jean Paul Veiga da; SCHAPIRO, Mario Gomes. Direito Econômico Atual. Rio de Janeiro: Forense; São Paulo: Método, 2015, pp. 321-353.

MAZZUOLI, Valério de Oliveira. Curso de Direito Internacional Público. $3^{\text {a }}$ edição. São Paulo: Editora Revista dos Tribunais, 2008.

MEDRADO, Renê Guilherme da Silva; DAUDT, André Rossetto. Acordos Internacionais de Investimento: o novo modelo brasileiro. 01/12/2015. Disponível em $\mathrm{http}: / / \mathrm{www}$.pinheironeto.com.br/Pages/publicacoes-detalhes.aspx ?nID=330. Acesso em 17/12/2016.

MEDEIROS, Wagner. O que falta ao sistema público de financiamento e garantia das exportações? Banco ou recursos? RBCE, vol. 104, Julho/Agosto/Setembro de 2010, pp. 1829.

MISSIO, Fabrício; JACOBI, Luciane Flores. Variáveis dummy: especificações de modelos com parâmetros variáveis. Ciência e Natura, UFSM, 29 (1), 2007, pp. 111-135.

MORAVCSIK, Andrew M. Disciplining trade finance: the OECD Export Credit Arrangement. International Organization, Vol. 43, No. 1, 1989, pp.173 -205

Multilateral Investment Guarantee Agency, Word Bank Group. South-South Foreign Direct Investment and Political Risk Insurance: Challenges and Opportunities. In: SAUVANT, Karl P; MCALLISTER, Geraldine; MASCHEK, Wolgang A. Foreign Direct Investment from Emerging Enterprises. Palgrave Macmillan, 2010, pp. 227-242.

NETO, José Serrador. O contencioso comercial Embraer-Bombardier. In: BENJAMIM, Daniela Arruda (Coord). O sistema de solução de controvérsias da OMC: uma perspectiva brasileira. Editora Fundação Alexandre de Gusmão. Brasília: 2013, pp. 281-312.

OECD. Organisation for Economic Co-operation and Development. Multilateral Investment Insurance. Section of International and Comparative Law Bulletin 6.2 (1961-1962)

Smart Rules for Fair Trade: 50 years of Export Credits. OECD Publishing, 2011. Disponível em http://dx.doi.org/10.1787/9789264111745-en.

OPIC. Overseas Private Investment Corporation. Annual Management Report Of The Overseas Private Investment Corporation For Fiscal Years 2015 And 2014.

PANZINI, Fabrizio Sardelli; BIASUTTI, Constanza Negri. O retorno dos Acordos de Investimentos na agenda comercial brasileira. RBCE, vol 123 - Abril/Maio/Junho de 2015, pp. 58-72. 
PINTO, Daniel Roberto. Muito mais que a EMBRAER: os contenciosos Brasil-Canadá e o país que queremos ser. In: BENJAMIM, Daniela Arruda (Coord). O sistema de solução de controvérsias da OMC: uma perspectiva brasileira. Editora Fundação Alexandre de Gusmão. Brasília: 2013, pp. 45-84.

RAMALHO, Marcus Vinicius. A resolução do contencioso Embrar-Bombardier: a revisão do entendimento setorial aeronáutico da OCDE. In: BENJAMIM, Daniela Arruda (Coord). $O$ sistema de solução de controvérsias da OMC: uma perspectiva brasileira. Editora Fundação Alexandre de Gusmão. Brasília: 2013, pp. 649-668.

RAMSEY, Jase Ryan; BARAKAT, Livia Lopes; CREITOIU, Sherban Leonardo. Internationalization and its possible impact on subjective and objective performance: Evidence from Brazilian TNCs. Transnational Corporations, v. 21, n. 2, Aug. 2012.

REIS, Arthur Cézar Ferreira. As relações internacionais da América Latina nos séculos XIX e XX. In: Correia, Luis Felipe Seixas (Org). Relações internacionais do Brasil: Antologia comentada de artigos da Revista do IHGB (1841 - 2004). Editora Fundação Alexandre de Gusmão, 2016, pp. 337-382.

RESENDE, Paulo; ALMEIDA, André; RAMSEY, Jase. The transnationalisation of Brazilian companies: lessons from the Top Twenty multinational enterprises. In: SAUVANT, Karl P; MCALLISTER, Geraldine; MASCHEK, Wolgang A. Foreign Direct Investment from Emerging Enterprises. Palgrave Macmillan, 2010, pp. 97-112.

SAHOO, Pravakar; NATARAJ, Geethanjali; DASH, Ranhan Kumar. Foreign Direct Investment in South Asia: Policy, Impacts, Determinants and Challenges. Springer India: Delhi, 2014.

SALCIC, Zlatko. Export Credit Insurance \& Guarantees. A practitioner's Guide. Palgrave Macmillan, 2014.

SANTOS, Rodrigo de Azeredo. A criação do fundo de garantia do Mercosul; vantagens $e$ proposta - Brasília: Fundação Alexandre de Gusmão, 2011.

SCHAPIRO, Mario Gomes. Política Industrial, Direito e Desenvolvimento: razões econômicas, experiências institucionais e racionalidades regulatórias. In.

(coord.) Direito Econômico Regulatório. Série GV Law. Sao Paulo: Saraiva, 2010a, 425469

Novos Parâmetros para a intervenção do estado na economia: persistência e dinâmica na atuação do BNDES em uma economia baseada no conhecimento. São Paulo: Saraiva, 2010b.

SCHREUER, Christoph H; MALINTOPPI, Loretta; REINISCH, August; SINCLAIR, Anthony. The ICSID Convention: a commentary. $2^{\text {nd }}$ edition. Cambridge University Press, 2009.

SETTE FORTES, Marcio Eduardo. Competitividade, internacionalização e riscos econômicos. $R B C E$ vol. 109, 2011, pp. 28-35. 
SILVA, Ana Rachel Freitas da. O financiamento público das exportações brasileiras e a regulamentação sobre subsídios da Organização Mundial do Comércio. Olinda: Livro Rápido, 2014.

SÖDERSTEN, Bo; REED, Geoffrey. International Economics. $3^{\text {rd }}$ edition. Macmillan, 1994.

SORNARAJAH, M. The international Law of Foreign Investment. 3. Ed. Cambridge University Press, 2010.

SPERO, Joan Edelman; HART, Jeffrey A. The Politics of International Economic Relations. $5^{\text {th }}$ edition. St. Martin's Press: New York, 1997.

TAMBURINI, Francesco. Historia y destino de la "doctrina calvo": ¿actualidad u obsolescencia del pensamiento de Carlos Calvo? Rev. estud. hist.-juríd., Valparaíso , n. 24, p. 81-101, 2002. Disponível em http://www.scielo.cl/scielo.php?script=sci_arttext\&pid=S0716-

$54552002002400005 \& \operatorname{lng}=$ es\&nrm=iso>. Acesso em 16.02.2017.

TAN, Khee Giap; TAN, Kong Yam. Foreign Direct Investment (FDI), Productivity Spillovers and the Role of Small and Medium Enterprises (SMEs) Financing: In: (idem, ibidem). Foreign Direct Investment and Small and Medium Enterprises: productivity and Access to Finance. World Scientific: Singapore, 2015.

UNCTAD. Handbook on outward Investment Agencies and Institutions. ASIT Advisory Studies, nº 14. Geneva: United Nations, 1999.

World Investment Report 2016: reforming international investment governance. Geneva: United Nations, 2016.

. Megagrouping Investment Facts and Figures. Division on Investment and Enterprise. Geneva: United Nations, 2016.

VEIGA, Pedro da Motta; RIOS, Sandra Polónia. Os investimentos brasileiros no exterior: características, motivações e agenda de políticas. $R B C E$ vol. 118, Janeiro-Março 2014, pp. 66-89.

VIEITAS, Deborah; ABOIM, Isabel. África: oportunidades para empresas brasileiras. $R B C E$ vol. 116, Julho-Setembro 2013, pp. 20-33.

WHEATLEY, Jonanthan. Globalisation: companies must expand to prosper. Financial Times. Londres, 14/11/2010. Disponível em https://www.ft.com/content/a9288530-edfe11df-8616-00144feab49a. Acesso em 17/12/16. 


\section{Apêndice: Minuta de Projetos de LeI}

\begin{tabular}{|c|c|}
\hline Pro & \\
\hline 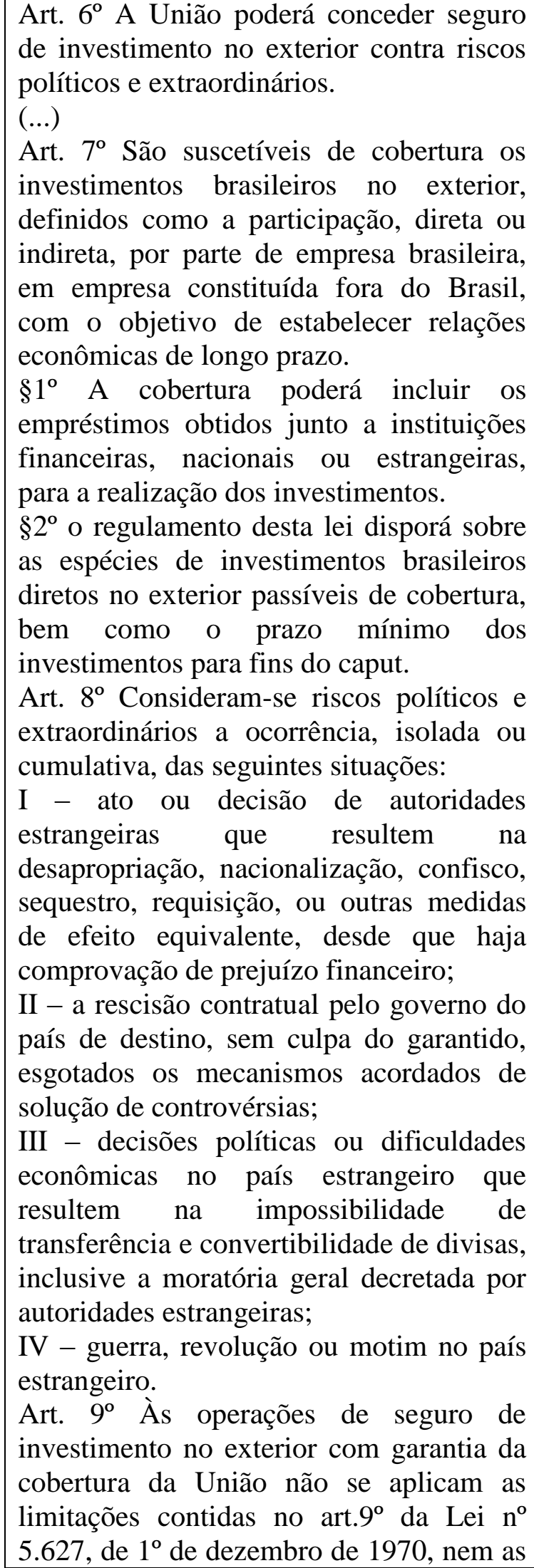 & $\begin{array}{l}\text { políticos e extraordinários. } \\
\text { (...) } \\
\text { Art. } 7^{\circ} \text { São suscetíveis de cobertura os } \\
\text { investimentos brasileiros no exterior, } \\
\text { definidos como a participação, direta ou } \\
\text { indireta, por parte de empresa estabelecida } \\
\text { no Brasil ou subsidiária estrangeira de } \\
\text { empresa brasileira, em empresa } \\
\text { constituída fora do Brasil, com o objetivo } \\
\text { de estabelecer relações econômicas de } \\
\text { longo prazo. } \\
\text { §10 A cobertura poderá incluir os } \\
\text { empréstimos obtidos junto a instituições } \\
\text { financeiras, nacionais ou estrangeiras, } \\
\text { para a realização dos investimentos. } \\
\text { §2 o regulamento desta lei disporá sobre } \\
\text { as espécies de investimentos brasileiros } \\
\text { diretos no exterior passíveis de cobertura, } \\
\text { bem como o prazo mínimo dos } \\
\text { investimentos para fins do caput. } \\
\text { Art. } 8^{\circ} \text { Consideram-se riscos políticos e } \\
\text { extraordinários a ocorrência, isolada ou } \\
\text { cumulativa, das seguintes situações: } \\
\text { I - ato ou decisão de autoridades } \\
\text { estrangeiras que resultem, direta ou } \\
\text { indiretamente, na desapropriação, } \\
\text { nacionalização, confisco, sequestro, } \\
\text { requisição, ou outras medidas de efeito } \\
\text { equivalente, desde que haja comprovação } \\
\text { de prejuízo financeiro; } \\
\text { II - a rescisão contratual pelo governo do } \\
\text { país de destino, sem culpa do garantido, } \\
\text { esgotados os mecanismos acordados de } \\
\text { solução de controvérsias; } \\
\text { III - decisões políticas ou dificuldades } \\
\text { econômicas no país estrangeiro que } \\
\text { resultem na impossibilidade } \\
\text { transferência e convertibilidade de divisas, } \\
\text { inclusive a moratória geral decretada por } \\
\text { autoridades estrangeiras; } \\
\text { IV - guerra, revolução ou motim no país } \\
\text { estrangeiro. } \\
\text { V - catástrofes naturais, tais como } \\
\text { ciclones, inundações, terremotos, erupções }\end{array}$ \\
\hline
\end{tabular}




\begin{tabular}{|c|c|}
\hline $\begin{array}{l}\text { disposições do Decreto-Lei } \mathrm{n}^{\circ} 73 \text {, de } 21 \\
\text { de novembro de } 1966 \text {. } \\
\text { Art. } 10^{\circ} \text { Nas operações de seguro de } \\
\text { investimento no exterior não serão } \\
\text { devidas comissões de corretagem. }\end{array}$ & $\begin{array}{l}\text { vulcânicas e maremotos. } \\
\text { Art. } 9^{\circ} \text { Não será concedida cobertura para } \\
\text { investimentos sem a avaliação de } \\
\text { conformidade em matérias social, } \\
\text { ambiental, trabalhista e anticorrupção, nos } \\
\text { termos do regulamento. } \\
\text { Art. } 10 \text { Âs operações de seguro de } \\
\text { investimento no exterior com garantia da } \\
\text { cobertura da Unaão não se aplicam as } \\
\text { limitações contidas no art.9 da Lei no } \\
5.627 \text {, de } 1^{\circ} \text { de dezembro de } 1970 \text {, nem as } \\
\text { disposições do Decreto-Lei no } 73 \text {, de } 21 \\
\text { de novembro de } 1966 \text {. } \\
\text { Art. } 11 \text { Nas operações de seguro de } \\
\text { investimento no exterior não serão } \\
\text { devidas comissões de corretagem }\end{array}$ \\
\hline
\end{tabular}

